\title{
Mineral Resources of the Hells Canyon Study Area, Wallowa County, Oregon, and Idaho and Adams Counties, Idaho
}

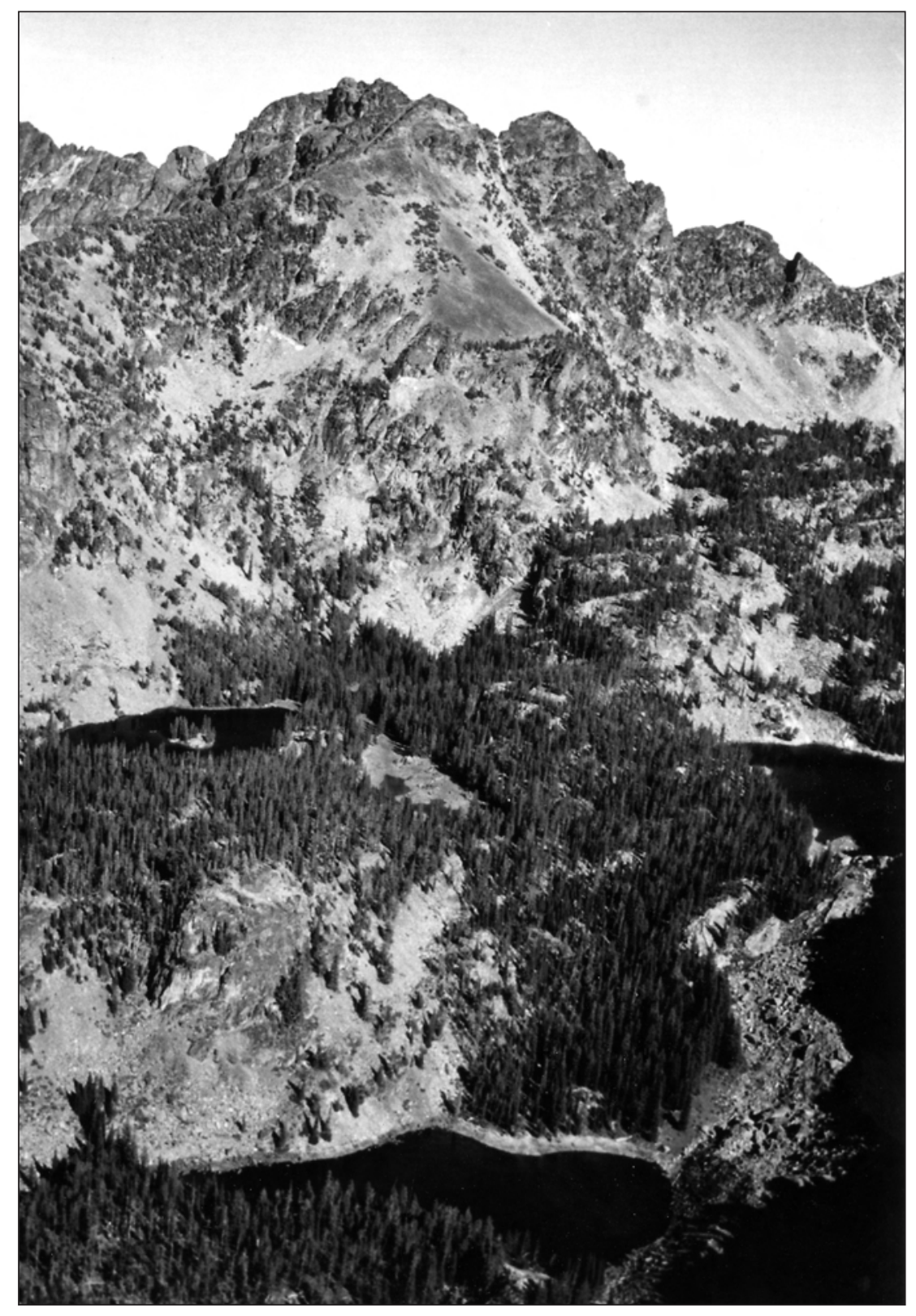

Scientific Investigations Report 2007-5046 
Cover. He Devil, 2,863 m, is highest peak in the Seven Devils Mountains. 


\section{Mineral Resources of the Hells Canyon Study Area, Wallowa County, Oregon, and Idaho and Adams Counties, Idaho}

By George C. Simmons and James L. Gualtieri, U.S. Geological Survey, and Terry J. Close, Francis E. Federspiel, and Andrew M. Leszcykowski, U.S. Bureau of Mines

With a section on Aeromagnetic and Gravity Surveys by Don R. Mabey, U.S. Geological Survey

Studies Related to Wilderness-Wilderness Areas

U.S. Geological Survey Scientific Investigations Report 2007-5046

U.S. Department of the Interior

U.S. Geological Survey 


\title{
U.S. Department of the Interior DIRK KEMPTHORNE, Secretary
}

\author{
U.S. Geological Survey \\ Mark D. Myers, Director
}

\section{U.S. Geological Survey, Reston, Virginia: 2007}

For product and ordering information:

World Wide Web: http://www.usgs.gov/pubprod

Telephone: 1-888-ASK-USGS

For more information on the USGS-- the Federal source for science about the Earth, its natural and living resources, natural hazards, and the environment:

World Wide Web: http://www.usgs.gov

Telephone: 1-888-ASK-USGS

Any use of trade, product, or firm names is for descriptive purposes only and does not imply endorsement by the U.S. Government.

Although this report is in the public domain, permission must be secured from the individual copyright owners to reproduce any copyrighted materials contained within this report.

Suggested citation:

Simmons, G.C., Gualtieri, J.L., Close, T.J., Federspiel, F.E., and Leszcykowski, A.M., 2007, Mineral resources of the Hells Canyon study area, Wallowa County, Oregon, and Idaho and Adams Counties, Idaho, with a section on aeromagnetic and gravity surveys, by D.R. Mabey: U.S. Geological Survey Scientific Investigations Report 2007-5046, 62 p. 


\section{Contents}

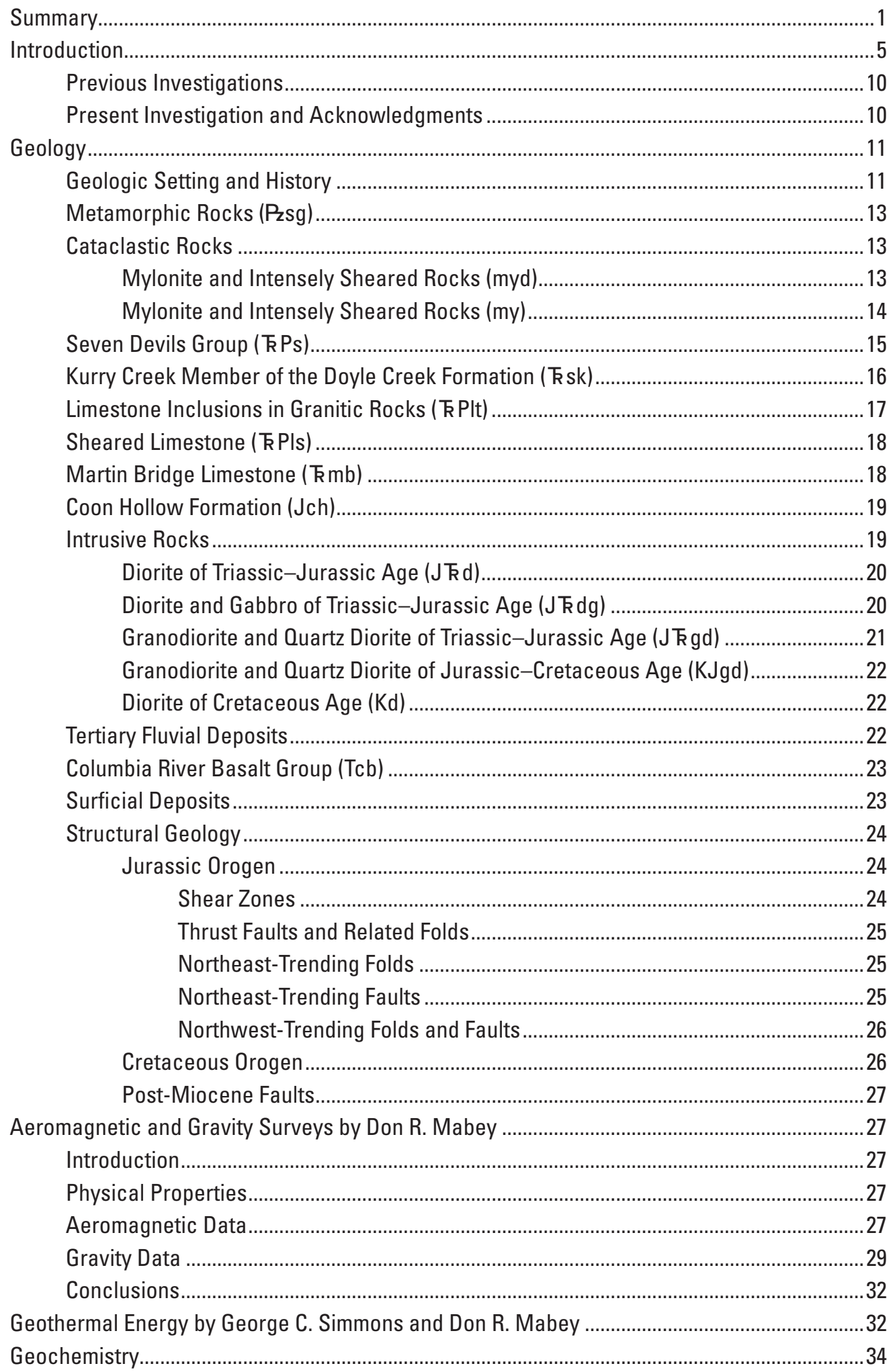




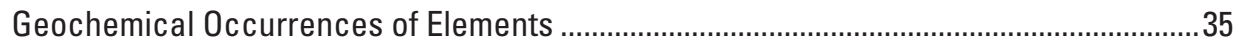

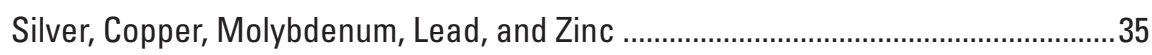

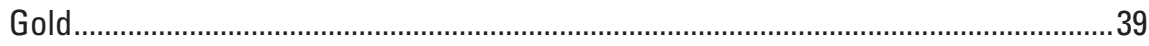

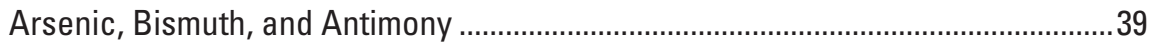

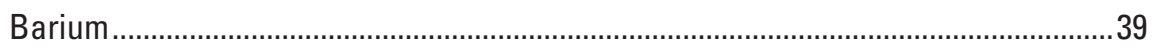

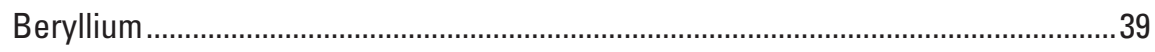

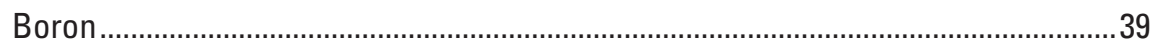

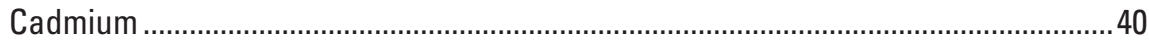

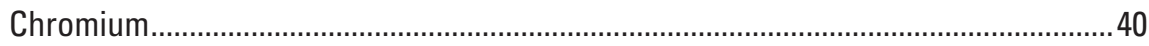

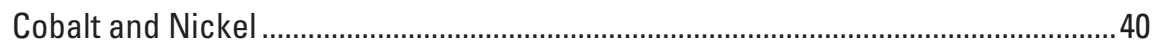

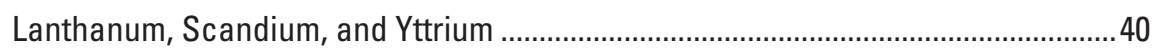

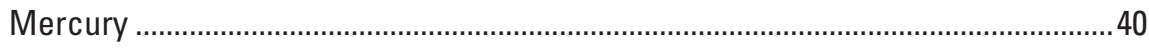

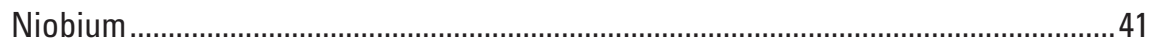

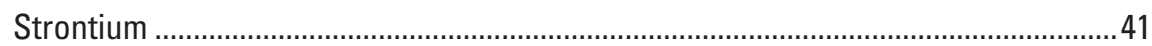

Tin

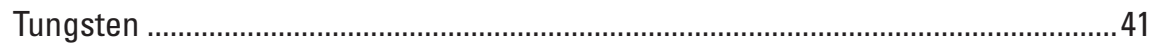

Uranium and Thorium ……................................................................................. 41

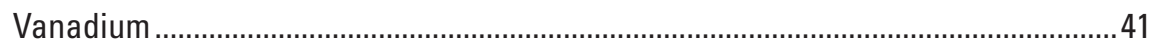

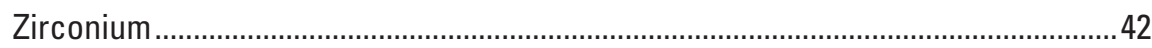

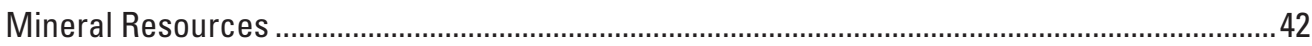

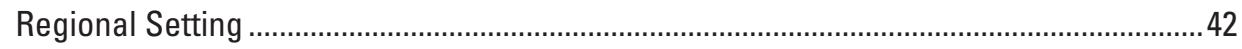

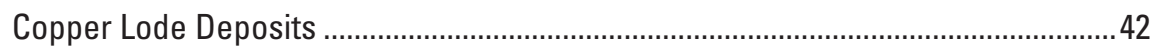

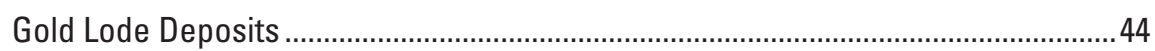

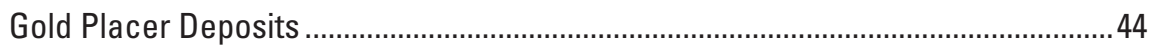

Mining Districts and Mineralized Areas by Terry J. Cose, Francis E. Federspiel, and

Andrew M. Leszcykowski......................................................................................... 44

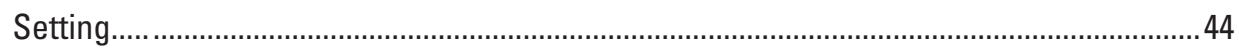

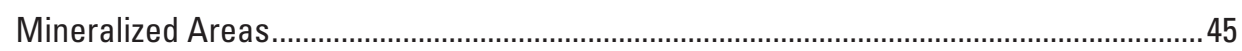

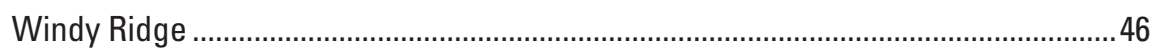

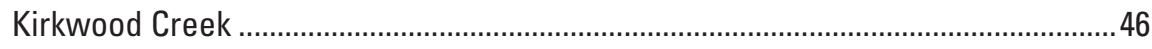

Imnaha-Salmon Rivers ........................................................................................... 4

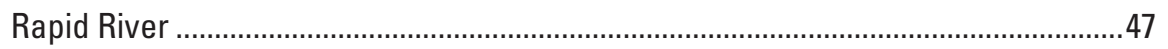

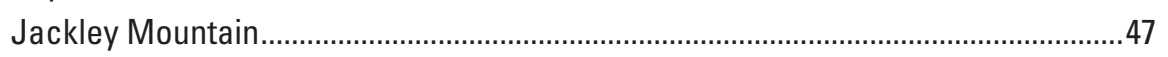

Miscellaneous Properties.................................................................................... 47

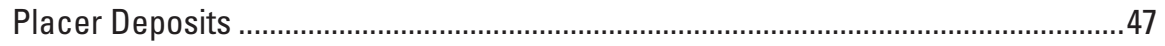

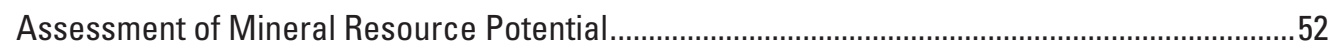

Silver, Copper, Molybdenum, Lead, and Zinc ………....................................................... 52

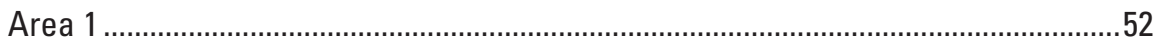

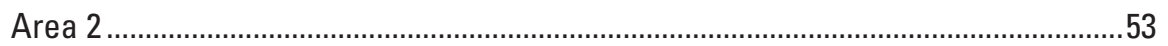

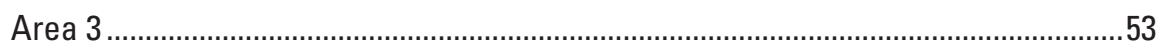

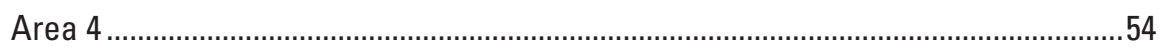

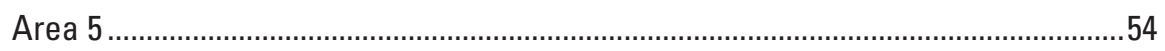

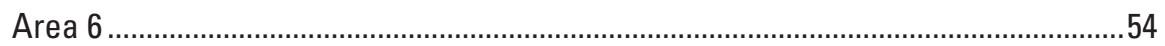

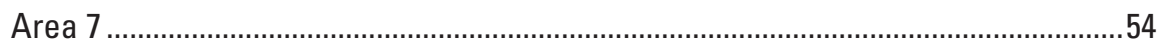

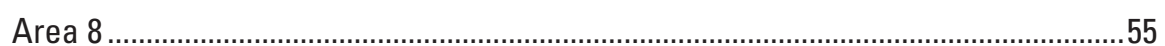




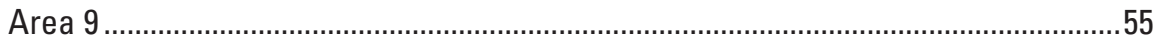

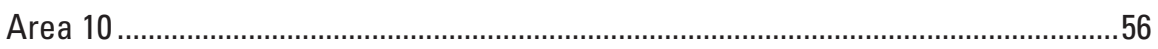

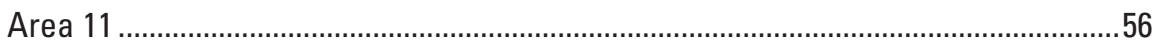

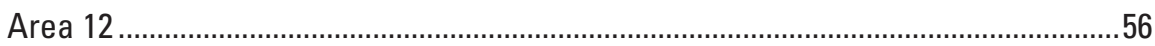

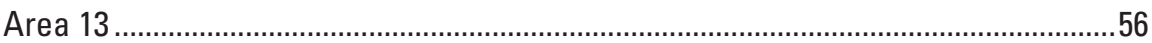

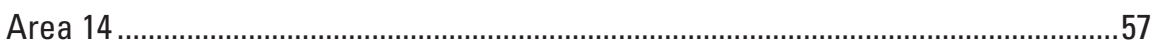

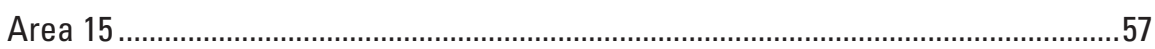

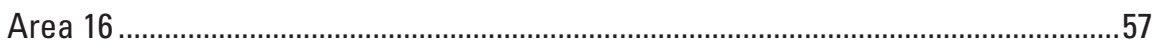

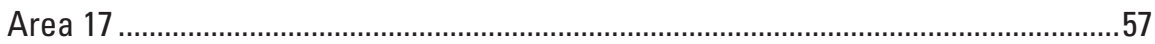

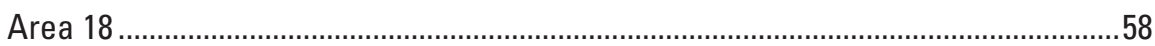

Area $19 \ldots \ldots \ldots \ldots$

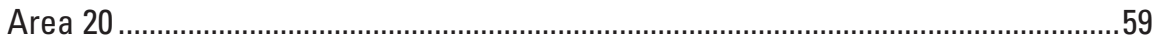

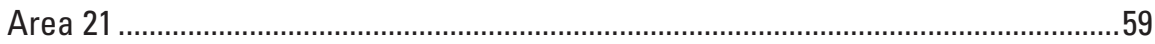

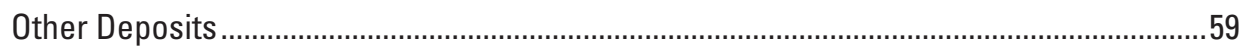

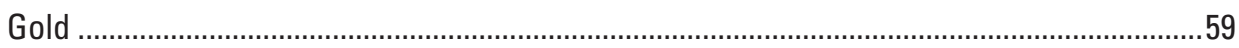

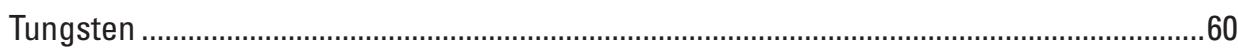

Nonmetallic Mineral Resources..................................................................................

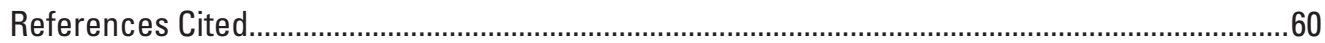

\section{Plates}

1. Reconnaissance geologic map of the south half of the Hells Canyon study area

2. Reconnaissance geologic map of the north half of the Hells Canyon study area

\section{Figures}

1. Location of the Hells Canyon study area and areas of mineral resource potential.... 2

2-8. Photographs:

2. View down Snake River and Hells Canyon from mouth of Saddle Creek ............ 7

3. View down Hells Canyon from cliffs east of Barton Heights................................. 7

4. Aerial oblique view of the Seven Devils Mountains .............................................. 8

5. View down the canyon of Imnaha River ................................................................ 8

6. Aerial oblique view of plateau remnants with forests and meadows between Snake and Imnaha Rivers ................................................................................ 9

7. Dissected mid-canyon bench along Snake River ....................................................

8. Confluence of Salmon and Snake Rivers ........................................................... 10

9. Residual magnetic intensity map of Hells Canyon study area and vicinity .................30

10. Constant terrain clearance residual aeromagnetic map of Hells Canyon study

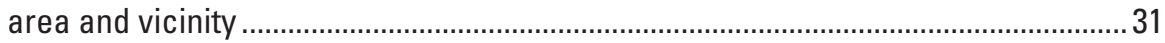

11. Complete Bouguer gravity anomaly map of Hells Canyon study area ........................ 33

12. Map showing mines, prospects, and mineralized areas.......................................... 48 


\section{Tables}

1. Fossil collections from limestones in the Seven Devils Group .................................. 17

2. Density and magnetic susceptibility of rocks in the Hells Canyon study area .......... 28

3. Threshold values for geochemical anomalies ............................................................. 36

4. Samples containing anomalous amounts of gold from the Hells Canyon study

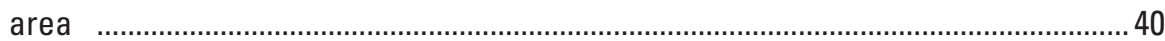

5. Samples containing anomalous amounts of tin from the Hells Canyon study

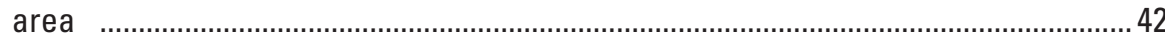

6. Estimates of gold, silver, and copper resources in lode deposits in the Hells Canyon study area 


\section{Studies Related to Wilderness}

Under the provisions of the Wilderness Act (Public Law 88-577, September 3, 1964) and related acts, the U.S. Geological Survey and the U.S. Bureau of Mines have been conducting mineral surveys of wilderness and primitive areas. Areas officially designated as "wilderness," "wild," or "canoe" when the act was passed were incorporated into the National Wilderness Preservation System, and some of them are presently being studied. The act provided that areas under consideration for wilderness designation should be studied for suitability for incorporation into the Wilderness System. The mineral surveys constitute one aspect of the suitability studies. The act directs that the results of each survey are to be made available to the public and be submitted to the President and the Congress. This report discusses the results of a mineral survey of the Hells Canyon study area, which includes the Hells Canyon Wilderness, parts of the Snake River, Rapid River, and West Fork Rapid River Wild and Scenic Rivers, lands included in the Roadless Area Review and Evaluation (RARE II), and parts of the Hells Canyon National Recreation Area, all in the Wallowa-Whitman National Forest in Wallowa County, Oregon, and the Nezperce and Payette National Forests in Idaho and Adams Counties, Idaho. The Hells Canyon Wilderness, the Wild and Scenic Rivers, and the Hells Canyon National Recreation Area were established in 1975 by the Hells Canyon Act (Public Law 94-199). 


\title{
Studies Related to Wilderness-Wilderness Areas
}

\section{Mineral Resources of the Hells Canyon Study Area, Wallowa County, Oregon, and Idaho and Adams Counties, Idaho}

\author{
By George C. Simmons, ${ }^{1}$ James L. Gualtieri,, Terry J. Close, ${ }^{2}$ Francis E. Federspiel, ${ }^{2}$ and Andrew M. \\ Leszcykowski
}

\section{Summary}

Field studies supporting the evaluation of the mineral potential of the Hells Canyon study area were carried out by the U.S. Geological Survey and the U.S. Bureau of Mines in 1974-76 and 1979. The study area includes (1) the Hells Canyon Wilderness; (2) parts of the Snake River, Rapid River, and West Fork Rapid River Wild and Scenic Rivers; (3) lands included in the second Roadless Area Review and Evaluation (RARE II); and (4) part of the Hells Canyon National Recreation Area. The survey is one of a series of studies to appraise the suitability of the area for inclusion in the National Wilderness Preservation System as required by the Wilderness Act of 1964. The spectacular and mineralized area covers nearly $950 \mathrm{mi}^{2}\left(2,460 \mathrm{~km}^{2}\right)$ in northeast Oregon and west-central Idaho at the junction of the Northern Rocky Mountains and the Columbia Plateau.

Most of the Hells Canyon study area has a low potential for mineral resources (fig. 1); however, about 4 percent of the study area, in 21 separate areas totaling $42 \mathrm{mi}^{2}\left(108 \mathrm{~km}^{2}\right)$, have moderate or high potential for resources of silver, copper, lead, zinc, gold, molybdenum, and tungsten. The 21 areas are interspersed in lands having a low potential, and are concentrated in the southern part of the study area. Nine of the areas and parts of seven others are in the Hells Canyon Wilderness. Thirty-four lode deposits within the study area have submarginal and paramarginal resources totaling about 31 million tons (28 million t) containing copper, silver, zinc, gold, and lead; another 37 lodes, not sufficiently exposed to allow resource estimates, are believed to contain mineral resources. The most important deposits are copper-, silver-, zinc-, gold-, and lead-bearing volcanogenic occurrences, followed by silver- and copper-bearing contact replacement (tactite) deposits; other lode occurrences are relatively unimportant. The most important placer deposits are at Dry Diggins (on Dry Diggins Ridge); placers along the Snake River are small and scattered. The study area has extensive deposits of limestone and sand and gravel; it has little potential for energy resources.

Four principal fields of investigation were coordinated in evaluating the mineral potential: (1) reconnaissance geologic mapping was carried out to ascertain the petrology and distribution of rocks, their stratigraphic, structural, and metamorphic relations, and whatever controls these features might impose on sites of mineral deposition; (2) a geochemical sampling program, assisted by statistical analyses, was made to determine the kinds and amounts of metals in different rocks, where anomalous amounts of metals exist, and to identify patterns of anomalies that could indicate mineralized areas; (3) an aeromagnetic survey was made to determine if the anomalies in the magnetic field correlate with geologic features and geochemical patterns, thereby suggesting the position of ore bodies, and possibly delineating mineralized areas that were not previously recognized; and (4) a study of all mines and prospects that could be found and of all mining records to identify the location and types of deposits, to determine the amounts and kinds of ores that had been mined, and to identify the present resources. The U.S. Geological Survey carried out parts (1) through (3); the U.S. Bureau of Mines conducted part (4). An assessment of mineral potential based on all four parts concludes the report.

The geologic history of the Hells Canyon region includes several periods of volcanic activity, major orogenic movements, intrusion, and metamorphism. The sequence of events has been determined to the extent that much of the history can be reconstructed. During the Permian, volcanic and volcaniclastic rocks were deposited. Toward the end of that period, or

${ }^{1}$ U.S. Geological Survey

${ }^{2}$ U.S. Bureau of Mines 

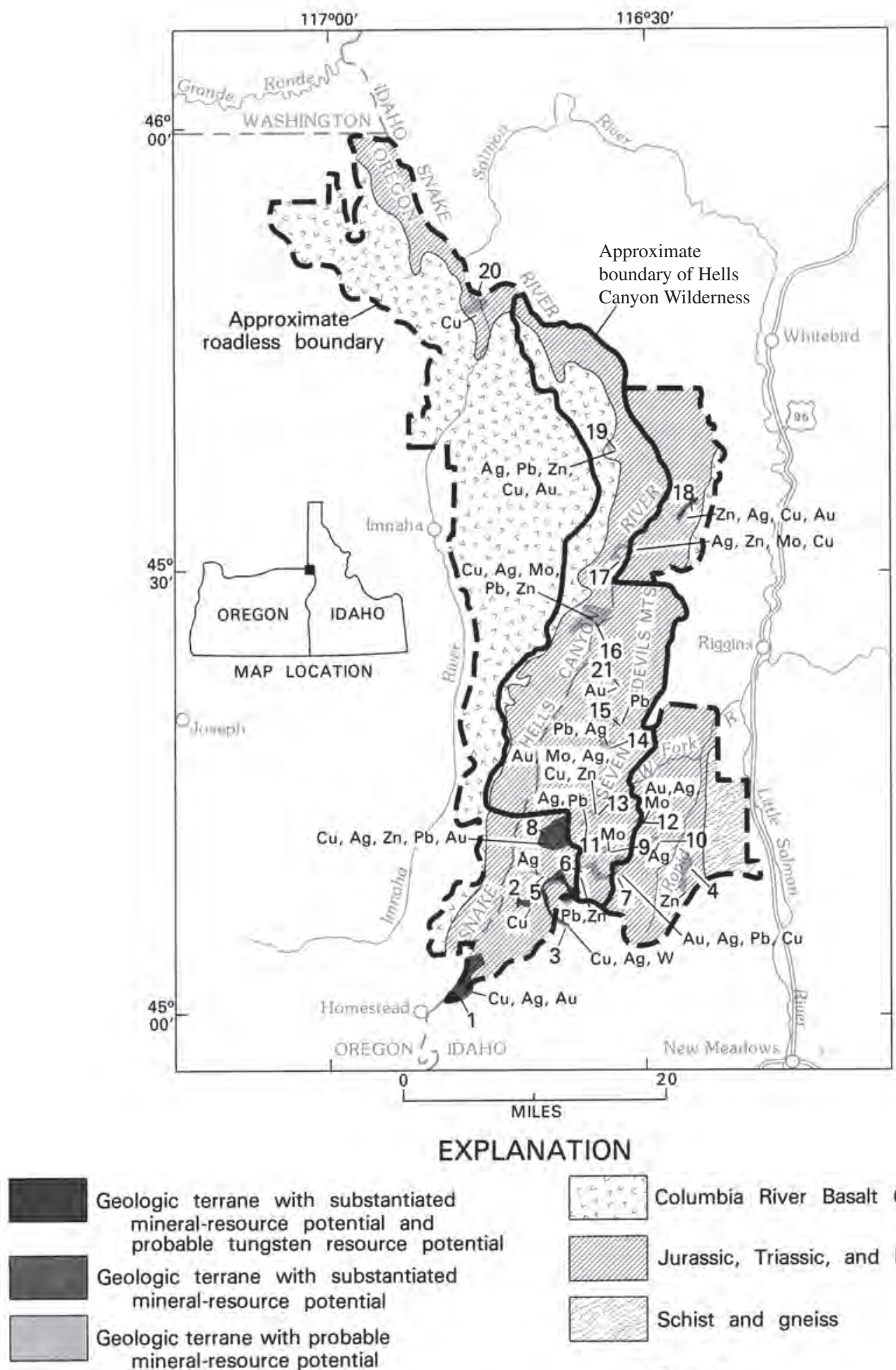

Geologic terrane with substantiated mineral-resource potential and probable tungsten resource potential

Geologic terrane with substantiated mineral-resource potential

Geologic terrane with probable mineral-resource potential

$\begin{array}{llll}\text { Cu } & \text { Copper } & \text { Ag } & \text { Silver } \\ \text { Au Gold } & \text { W } & \text { Tungsten } \\ \text { Pb } & \text { Lead } & \text { Zn } & \text { Zinc } \\ \text { Mo } & \text { Molybdenum } & & \end{array}$

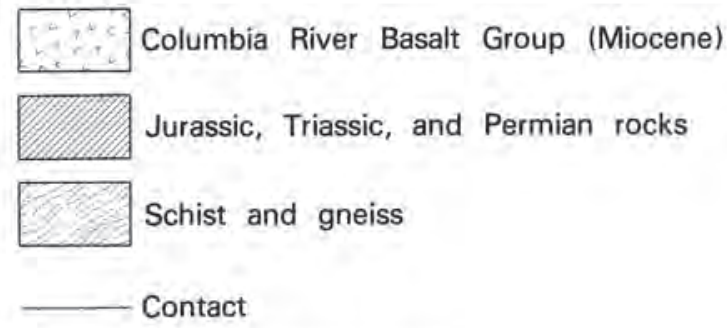

2 Area discussed in text

Figure 1 (above and facing page). Location of Hells Canyon study area and areas of mineral resource potential in the Hells Canyon study area. Modified from Simmons and Close, 1984. (For additional information on resource potential, see Simmons and others, 1983, 1984.) 


\begin{tabular}{|c|c|c|c|}
\hline Area & $\begin{array}{l}\text { Type of } \\
\text { deposit }\end{array}$ & Metals & $\begin{array}{l}\text { Resource } \\
\text { potential }^{1}\end{array}$ \\
\hline 1 & Volcanogenic & Copper-silver-gold & Moderate. \\
\hline 2 & Volcanogenic & Copper & Moderate. \\
\hline \multirow[t]{4}{*}{3} & Tactite & Copper-silver & High. \\
\hline & Tactite & Tungsten & Moderate. \\
\hline & Volcanogenic & Copper & Moderate. \\
\hline & Porphyry & Copper & Moderate. \\
\hline 4 & Unknown & Zinc & Moderate. \\
\hline 5 & Volcanogenic & Silver & Moderate. \\
\hline 6 & Volcanogenic & Lead-zinc & Moderate. \\
\hline \multirow[t]{2}{*}{7} & Vein & Gold-silver & Moderate. \\
\hline & Volcanogenic & Lead-silver-copper & Moderate. \\
\hline 8 & Volcanogenic & $\begin{array}{l}\text { Copper-silver-zinc- } \\
\text { lead-gold. }\end{array}$ & High. \\
\hline 9 & Volcanogenic & Molybdenum & Moderate. \\
\hline 10 & Volcanogenic & Silver & Moderate. \\
\hline 11 & Volcanogenic & Silver-lead & Moderate. \\
\hline \multirow[t]{2}{*}{12} & Vein & Gold-silver & Moderate. \\
\hline & Volcanogenic & Molybdenum-silver & Moderate. \\
\hline \multirow[t]{2}{*}{13} & Vein & Gold-silver & Moderate. \\
\hline & Volcanogenic & $\begin{array}{l}\text { Silver-copper-zinc- } \\
\text { molybdenum. }\end{array}$ & Moderate. \\
\hline 14 & Volcanogenic & Lead-silver & Moderate. \\
\hline 15 & Volcanogenic & Lead & Moderate. \\
\hline 16 & Volcanogenic & $\begin{array}{l}\text { Copper-silver-molybdenum- } \\
\text { lead-zinc. }\end{array}$ & Moderate. \\
\hline 17 & Volcanogenic & $\begin{array}{l}\text { Silver-zinc-molybdenum- } \\
\text { copper }\end{array}$ & Moderate. \\
\hline 18 & Volcanogenic & Zinc-silver-gold & High. \\
\hline 19 & Volcanogenic & $\begin{array}{l}\text { Silver-lead-zinc- } \\
\text { copper-gold. }\end{array}$ & Moderate. \\
\hline 20 & Vein & Copper & Moderate. \\
\hline 21 & Placer & Gold & Moderate. \\
\hline
\end{tabular}


in the Early Triassic, the rocks were uplifted, deformed, and intruded by plutonic rocks ranging in composition from gabbro to granite. Following the uplift, in the Middle and Late Triassic, volcanic and volcaniclastic rocks were again deposited, and in places temporarily unaffected by volcanism, limestone was deposited. The volcanic and volcaniclastic rocks and the interbedded limestone make up the Lower Permian and Middle and Upper Triassic Seven Devils Group. Volcanism ceased during the Late Triassic and was followed by the deposition of the Upper Triassic Martin Bridge Limestone, in a thick layer presumably throughout the region.

From the time of deposition of the Martin Bridge Limestone until the Middle Jurassic, the Hells Canyon region was uplifted, concurrent with the emplacement of plutonic rocks similar to those emplaced during the earlier uplift, and older rocks were eroded. In the Middle and Late Jurassic, black mudstone, the Coon Hollow Formation, was deposited on deformed rocks of Triassic age. A major orogeny then folded and faulted the pre-existing rocks, metamorphosed volcanic rocks into greenstones, and emplaced another group of plutonic rocks.

At the end of the Jurassic, plutonic rocks were thrust northwestward in the central part of the study area, and limestone and greenstone were thrust in the same direction into the eastern part of the study area. The thrusting was followed in the Early Cretaceous by the intrusion of granitic plutons, notably in the southern part of the study area. Later during the Early Cretaceous, low- to high-grade metamorphism, most effective east of the study area, transformed volcanic and sedimentary rocks into slate, marble, schist, and gneiss, and shortly thereafter these foliated metamorphic rocks were thrust eastward into the southeastern part of the study area.

The region was subsequently uplifted and an erosion surface of mixed relief developed; mountains probably existed in the southeast and a few canyons were present in the north. Then, in the middle Miocene, basalt erupted from numerous fissures and inundated the older rocks with the possible exception of the peaks in the south; these flows are part of the Miocene Columbia River Basalt Group, which is now widespread in the western part of the study area. During the late Miocene and Pliocene, the region was subjected to warping and block faulting. This was followed in the latest Pliocene and Pleistocene by the erosion of Hells Canyon. The canyon attained nearly its present depth prior to Wisconsin glaciation.

During the Pleistocene, the mountainous southern part of the study area was glaciated, producing morainal deposits; some gravels were probably deposited then also. During the Holocene, alluvium was deposited along the Snake River and its tributaries, and colluvium and landslide debris were deposited at a few places.

The magnetic susceptibility of rocks in the Hells Canyon region is higher than the average for rocks in the upper continental crust- the 23 samples taken all tested greater than $4 \times 10^{-4} \mathrm{emu}$ per $\mathrm{cm}^{3}$. Gabbro, diorite, quartz diorite, and basalt of the Columbia River Basalt Group have the highest susceptibility. Sedimentary rocks and silicic volcanic rocks have the lowest susceptibility; the susceptibility of greenstones varies considerably, and may be high or low.

The magnetic field is complex, reflecting the strongly magnetized rocks and the high surface relief. The magnetic intensity is generally high west of the Snake River where the Columbia River Basalt Group is present, and is lower east of the river where that group is thinner and not so extensively distributed. Magnetic highs occur over many plutons. A northeast grain to magnetic anomalies east of the Snake River in the southern part of the study area appears related to tabular, northeast-trending plutons and a northeast-trending shear zone. The lowest magnetic intensities are over altered rocks of the Seven Devils Group.

Of the 5,268 geochemical samples collected throughout the study area, 4,757 were chemically analyzed. The analyzed samples include 3,834 rock samples, 898 stream-sediment samples, 1 panned concentrate, 22 soil samples, and 2 water samples. Anomalous amounts of gold, silver, copper, molybdenum, lead, tungsten, and zinc indicate possibilities for the discovery of ore bodies containing these metals, but the only consistent patterns of trace elements are those of silver, copper, molybdenum, lead, and zinc. Other associations are erratic or of too sparse occurrence to suggest mineral deposits.

Mineral deposits in the study area that have recorded or potential production include contact replacements (tactites), volcanogenic occurrences, quartz veins, magnetite-hematite fissure veins, and placers. The tactite deposits are associated chiefly with the granitic pluton between Indian Creek and Deep Creek, and involve the replacement of limestone, particularly by copper minerals, and to a lesser extent by tungsten and other minerals. The volcanogenic occurrences are widespread and include massive and disseminated syngenetic deposits and structurally controlled deposits; the structurally controlled deposits may have formed as a result of partial remobilization during the emplacement of plutons or regional metamorphism. The volcanogenic deposits contain copper, silver, and zinc, and lesser amounts of molybdenum, lead, and gold. Quartz veins bearing gold, small amounts of silver, and at a few places copper are associated with the tabular granitic plutons in the southeastern part of the study area. The magnetite-hematite fissure veins are localized in the gabbro-diorite-quartz diorite pluton near the mouth of the Imnaha River; the only metal of importance that they contain is copper. Three types of placer gold deposits were recognized: residual deposits overlying tactite deposits, elevated deposits on the pre-Columbia River Basalt Group erosion surface in the central part of the study area, and deposits along or in the bed of the Snake River.

Much of the mining in the study area took place before thorough records were maintained; the early history of mining is not well known. The first successful attempts were near White Monument where residual placer claims were staked in the 1870s. When these deposits were nearly exhausted, underlying tactite deposits were discovered and mined from the 1880s until 1906. During the latter part of this period and for a few years thereafter, claims were staked in many parts of the study area: on mineralized shear zones, tactite deposits, and volcanogenic 
lenses near Rapid River, until 1900; on magnetite-hematite fissure veins near the mouth of the Imnaha River, until 1915; on elevated placer deposits at Dry Diggins and at Crooks Corral (near the head of Corral Creek), until 1915; on quartz veins near Jackley Mountain, until 1910; on volcanogenic deposits near Kirkwood Creek, until 1915; and at isolated places elsewhere.

The Iron Dyke mine, $3 \mathrm{mi}(4.8 \mathrm{~km})$ south of the study area, operated from 1914 until 1928, and is presently (1980) being developed. After 1928, mining in the study area was sporadic until the discovery of the Copper Cliff mine, $1 \mathrm{mi}$ $(1.6 \mathrm{~km})$ east of the south end of the study area, in 1965. This discovery spurred exploration at the nearby Red Ledge mine and the Nix group of claims and near Kirkwood Creek in the study area. The Copper Cliff mine is the only mine currently operating in or near the study area.

County records of mining claims show that about 4,100 claims have been located in the study area since 1870. About 1,290 lode claims and 110 placer claims are in Oregon, and about 2,510 lode claims and 190 placer claims are in Idaho. U.S. Bureau of Land Management records list 186 patented claims; another 300 unpatented claims are currently held. Recorded production from 17 lode deposits in the study area total 55,785 tons $(50,607 \mathrm{t})$ of ore. The ore contained 9,355 troy ounces $(291 \mathrm{~kg})$ of gold, 225,530 troy ounces $(7,015 \mathrm{~kg})$ of silver, 6,109 tons $(5,542 \mathrm{t})$ of copper, 1 ton $(0.9 \mathrm{t})$ of lead, 40 tons $(36 \mathrm{t})$ of zinc and 180 pounds $(82 \mathrm{~kg})$ of tungsten trioxide. Recorded production from placer deposits is 605 troy ounces $(18.8 \mathrm{~kg})$ of gold. During the study 114 lode prospects as well as placers were examined by U.S. Bureau of Mines personnel. Most prospects were mapped, and all were sampled. About 900 lode and 270 placer samples were taken. Identified resources in the study area total 30,561,620 tons (27,725,500 t) containing copper, gold, silver, and zinc; the resources include $29,733,700$ tons $(26,974,400 \mathrm{t})$ of paramarginal resources and 827,920 tons $(751,090 \mathrm{t})$ of submarginal resources.

\section{Introduction}

The Hells Canyon study area covers nearly $950 \mathrm{mi}^{2}$ $\left(2,460 \mathrm{~km}^{2}\right)$ in a region of spectacular canyon and mountain scenery along the junction of the Northern Rocky Mountains and the Columbia Plateau. The study area forms an irregular, north-trending band along the Snake River within a rectangle bounded by lat $45^{\circ} 02^{\prime}$ and $46^{\circ} 00^{\prime}$ N., and long $116^{\circ} 19^{\prime}$ and $117^{\circ} 06^{\prime}$ W., and includes public lands of the WallowaWhitman National Forest in Wallowa County, Oregon, and the Nezperce and Payette National Forests in Idaho and Adams Counties, Idaho. In December 1975 Congress passed the Hells Canyon Act (Public Law 94-199) creating the Hells Canyon National Recreation Area, much of which is within the study area. Provisions of the act designated the Snake River, which there forms the boundary between Oregon and Idaho, and the Rapid River and its West Fork in Idaho as Wild and Scenic Rivers, and created the Hells Canyon Wilderness, all of which are within the study area. The present (1980) Hells Canyon Wilderness includes about $300 \mathrm{mi}^{2}$ $\left(777 \mathrm{~km}^{2}\right)$ in Oregon and Idaho. A portion of the remaining $650 \mathrm{mi}^{2}\left(1,683 \mathrm{~km}^{2}\right)$ was studied during the Roadless Area Review and Evaluation program (RARE II) as a potential addition to the Hells Canyon Wilderness (fig. 1).

The study area can be reached by roads and jeep trails, but travel within the area is chiefly by foot, horse, or boat. Four roads provide access to the Snake River, not all of which appear on the base maps (pls. 1 and 2): (1) a paved road owned by the Idaho Power and Light Company leads northward from the community of Oxbow, Oreg., just south of the study area, along the east side of the Hells Canyon Reservoir to a boat launching ramp below Hells Canyon Dam; this is the embarking point for most boat trips down the river and the dock for a jet boat serving the tourist trade in the upper part of Hells Canyon; (2) a gravel road that leads into Forest Service road 493 runs westward from White Bird, Idaho, to Pittsburg Landing; (3) a gravel road heading northward from Imnaha, Oreg., becomes Forest Service road 4260 that turns eastward to Dug Bar where the Forest Service patrol boat docks (the route duplicates part of the route of Chief Joseph and his Wallowa band of Nez Perce on their historic retreat of 1866); and (4) a private dirt road, a spur from Forest Service road 4680, reaches the Oregon side of the river at the mouth of Cache Creek near the north boundary of the study area. Approach to the river via the jeep trails to the mouths of Kirkwood and Getta Creeks is determined by the courage of the drivers, particularly along the lower segments of these routes.

Several Forest Service roads provide access to the margins of the study area and within the northwestern part of the study area. The most important among those in Idaho are the roads to the Cold Springs lookout tower (241 and 420) and the Seven Devils-Heavens Gate road (517), both of which connect with U.S. Highway 95 near Riggins. Others are the road from Cuprum to the abandoned mining district of Helena, the road from Hells Canyon Reservoir to the Red Ledge mine (impassable in 1980), the road from Landore to Black Lake, and the Kleinschmidt Grade that leads from Hells Canyon Reservoir to Cuprum.

Forest Service roads that can be reached from Enterprise, Joseph, and Imnaha, Oreg., afford means of reaching the study area on the west side of the Snake River. North of Imnaha and on the west side of the Imnaha River, the Broady Creek road (4665), the Dougherty Spring road (46), the Poison Point road (4600615), the Summit Creek road (4625), and the Summit Ridge road (46) extend to and along the boundary of the study area. The Teepee Butte road (4600595), the Cold Springs Ridge road (4680), the Jim Creek ranch road (4680250), the Cherry Creek ranch road (4600788), and the Spain Saddle road (4600780) penetrate the study area in the same vicinity. North of Imnaha on the east side of the Imnaha River two short spurs, the Cow Creek road (4260200) and the Horse Creek road (4260100), extend from the Dug Bar road (4260) into the study area.

The principal access road between the Imnaha and Snake Rivers is the one from Imnaha to Hat Point and the Memaloose 
Guard Station (4240); this road may soon be improved because Hat Point is being developed as an observation point for tourists. South of Imnaha and on the east side of the Imnaha River, the study area is reached by the Saulsbury Saddle road (3965) and the McGraw Spring road (along the ridge above McCraw Creek), which fork from the Imnaha River road (3960).

U.S. Forest Service trails provide access within much of the study area, and most of them are shown on the base maps (pls. 1 and 2). For more complete illustration of the trail system, one should refer to current maps of the National Forests and the Hells Canyon Recreation Area, which are periodically published by the U.S. Forest Service.

The study area contains a variety of physiographic features, the best known of which are the canyon of the Snake River (fig. 2) and the Seven Devils Mountains. The defile eroded by the Snake River is a rugged gorge, sometimes referred to as the Grand Canyon of the Snake River; the deepest part of the canyon, west of the Seven Devils Mountains, is called Hells Canyon (fig. 3), from where the wilderness and study areas take their names. The Seven Devils Mountains tower above the Idaho side of Hells Canyon, rising from steep and barren canyon walls, to heavily forested slopes, to alpine meadows, tarns, cirques, and rocky peaks above timberline (fig. 4). The area also contains the impressive canyons of the Rapid River in Idaho, the Imnaha in Oregon (fig. 5), and canyons of numerous tributaries to these and the Snake River. Among the other prominent landforms are the flat-topped ridges and plateau remnants with forests and meadows that form many interstream divides, particularly in Oregon (fig. 6). A dissected bench occurs midway between the rim and the bottom of the canyon of the Snake River (fig. 7), and the upper part of this bench coincides with the lowest appearance of abundant timber. A similar but less dissected bench occurs along the Imnaha River, but being at a somewhat lower elevation it is entirely in grasslands.

The highest point in the area is He Devil Mountain at 9,393 $\mathrm{ft}$ (2,863 m), in the Seven Devils Mountains; the lowest elevation is about $850 \mathrm{ft}(259 \mathrm{~m})$, on the Snake River where it flows northward out of the area. Thus, the total relief is about $8,543 \mathrm{ft}(2,604 \mathrm{~m})$. The elevation of the Snake River at its closest approach to He Devil, a horizontal distance of $5.3 \mathrm{mi}$ $(8.5 \mathrm{~km})$, is about $1,330 \mathrm{ft}(406 \mathrm{~m})$; so, the maximum local relief is about $8,063 \mathrm{ft}(2,457 \mathrm{~m})$. The general elevation difference from the rims to the bottom of the canyon of the Snake River along its $88 \mathrm{mi}(140 \mathrm{~km})$ length through the study area ranges from about 4,000 to $6,500 \mathrm{ft}(1,200$ to $2,000 \mathrm{~m})$ in the south to 3,000 to $4,000 \mathrm{ft}$ (900 to $1,200 \mathrm{~m}$ ) in the north.

The study area is entirely within the drainage basin of the Snake River, the largest tributary of the Columbia River. Much of the runoff discharges directly into the Snake River itself through short, precipitous side streams; the other runoff reaches the Snake River by three principal tributaries, the Grande Ronde, the Salmon, and the Imnaha Rivers, all of which flow in deep canyons similar to that eroded by the Snake. The northwest corner of the study area is drained by tributaries of the Grande Ronde, which flows into the Snake
River $7 \mathrm{mi}$ (11 km) downstream from the study area in Washington. The southeastern part of the study area is drained by the Rapid River, which flows into the Little Salmon River, which in turn joins the Salmon River at Riggins, Idaho; the Salmon flows into the Snake River in the northern part of the study area, $12 \mathrm{mi}$ $(19 \mathrm{~km})$ upstream from the boundary of Oregon and Washington (fig. 8). Much of the west side of the study area is drained by the Imnaha River, which flows into the Snake $4 \mathrm{mi}(6 \mathrm{~km})$ upstream from the confluence of the Salmon and Snake Rivers. The Snake River joins the Columbia River near Pasco, Wash., from where the waters of the region flow to the Pacific Ocean.

As would be expected in a region of great relief, the climate differs considerably from place to place, and several climatic zones are present. Summers are hot and winters are mild in the canyon bottoms, whereas the summers are mild and the winters are frigid at the higher elevations. The mean high temperature during July and August in the bottom of the canyon of the Snake River is about $90^{\circ} \mathrm{F}\left(32^{\circ} \mathrm{C}\right)$ with highs sometimes reaching $115^{\circ} \mathrm{F}\left(46^{\circ} \mathrm{C}\right)$; mean winter temperatures there are about $32^{\circ} \mathrm{F}\left(0^{\circ} \mathrm{C}\right)$. Between 4,000 and $6,000 \mathrm{ft}(1,200$ and $1,800 \mathrm{~m})$ the mean temperature is $61^{\circ} \mathrm{F}\left(16^{\circ} \mathrm{C}\right)$ in July and $20^{\circ} \mathrm{F}\left(-7^{\circ} \mathrm{C}\right)$ in January. Above $6,000 \mathrm{ft}(1,800 \mathrm{~m})$ the mean temperatures in July and January are $54^{\circ} \mathrm{F}\left(12^{\circ} \mathrm{C}\right)$ and $14^{\circ} \mathrm{F}$ $\left(-10^{\circ} \mathrm{C}\right)$, respectively.

Precipitation increases with elevation, ranging from less than $10 \mathrm{in} .(25 \mathrm{~cm})$ per year in the bottom of the canyon to more than 50 in. $(127 \mathrm{~cm})$ per year in the Seven Devils Mountains. Snow rarely falls in the bottom of the canyon, but above $5,000 \mathrm{ft}(1,500 \mathrm{~m}) 70$ percent of the precipitation is snow, and snow can fall any day of the year in the Seven Devils Mountains.

Vegetation differs according to elevation, climate, availability of water, directions in which slopes face, and soil depth and composition. The riversides and the stream banks at lower elevations are dominated by Douglas hackberry, although a few ponderosa pine are present. Cheatgrass and poison ivy are commonly associated with the hackberry. Along the narrower side canyons containing perennial streams, white alder, box alder, and water birch are common, as are chokecherry and bittercherry shrubs. These riparian zones are small however, and below 4,000 ft (1,200 m) few trees grow far from water courses, the slopes being covered by cheatgrass. With an increase in elevation, the first tree to appear in numbers is the ponderosa pine and then the Douglas fir, first only on northfacing slopes, and then forming forests on all slopes. At higher elevations are lodgepole, limber, and white pines, Englemann spruce, white and subalpine fir, western larch or tamarack, and a great variety of subalpine and alpine plants.

The most common larger animals are elk, mule deer and white-tailed deer, bear, cougar, and bobcat; less common are mountain goat and mountain sheep. Small animals include mink, otter, beaver, badger, raccoon, skunk, squirrel, coyote, and porcupine. Among the frequently seen birds are the ouzel or dipper, canyon wren, golden eagle, raven, vulture, hawks, owls, Steller's and Canada jays, Clark's nutcracker, and chickadee. Game birds include chukar, partridge, grouse, 


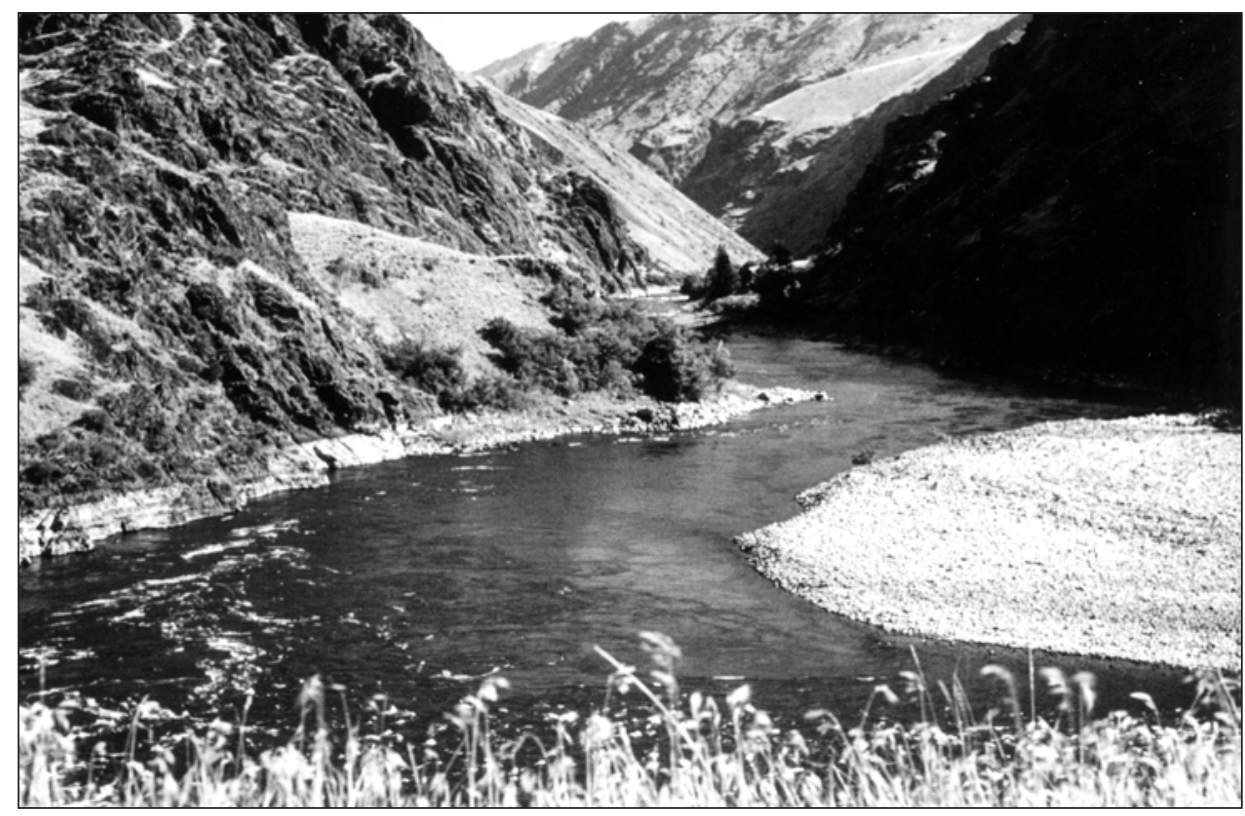

Figure 2. View northeast down Snake River and Hells Canyon from mouth of Saddle Creek, Oreg. (Photograph taken August 21, 1974).

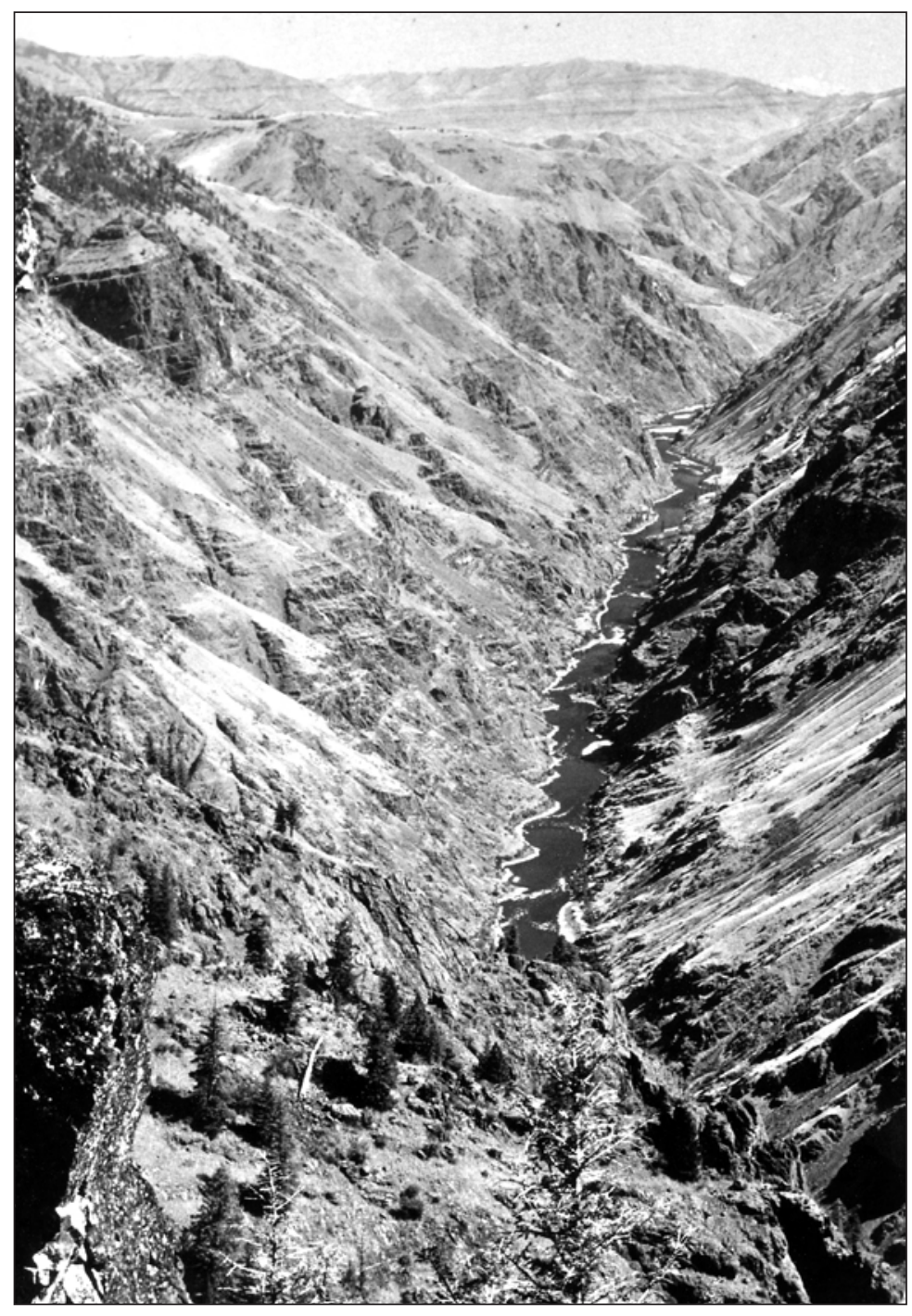

Figure 3. View north down Hells Canyon from cliffs east of Barton Heights, Oreg. (Photograph taken August 11, 1976). 


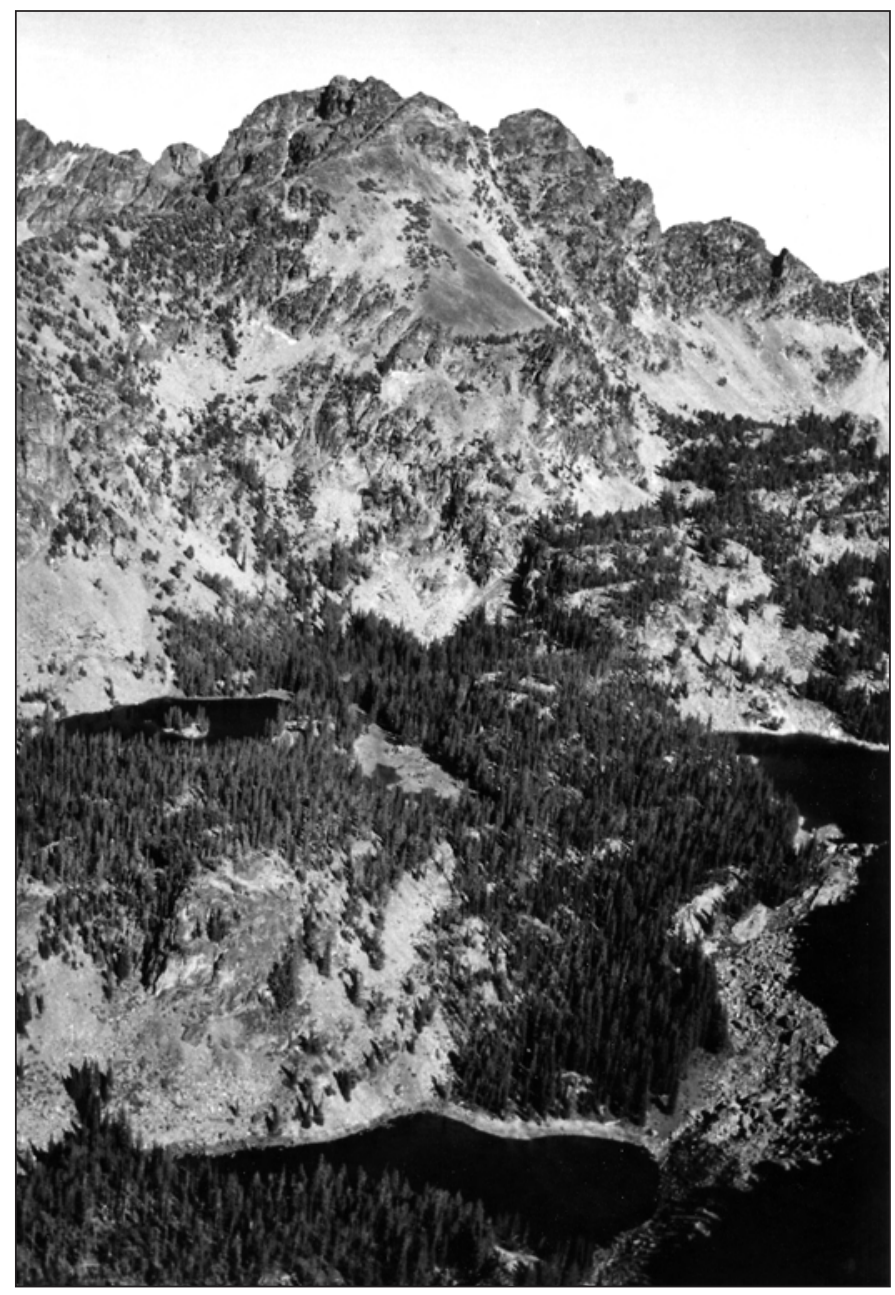

Figure 5. View north down Imnaha River, about $1 \mathrm{mi}$ $(1.6 \mathrm{~km})$ from confluence with Snake River. (Photograph taken September 12, 1974).

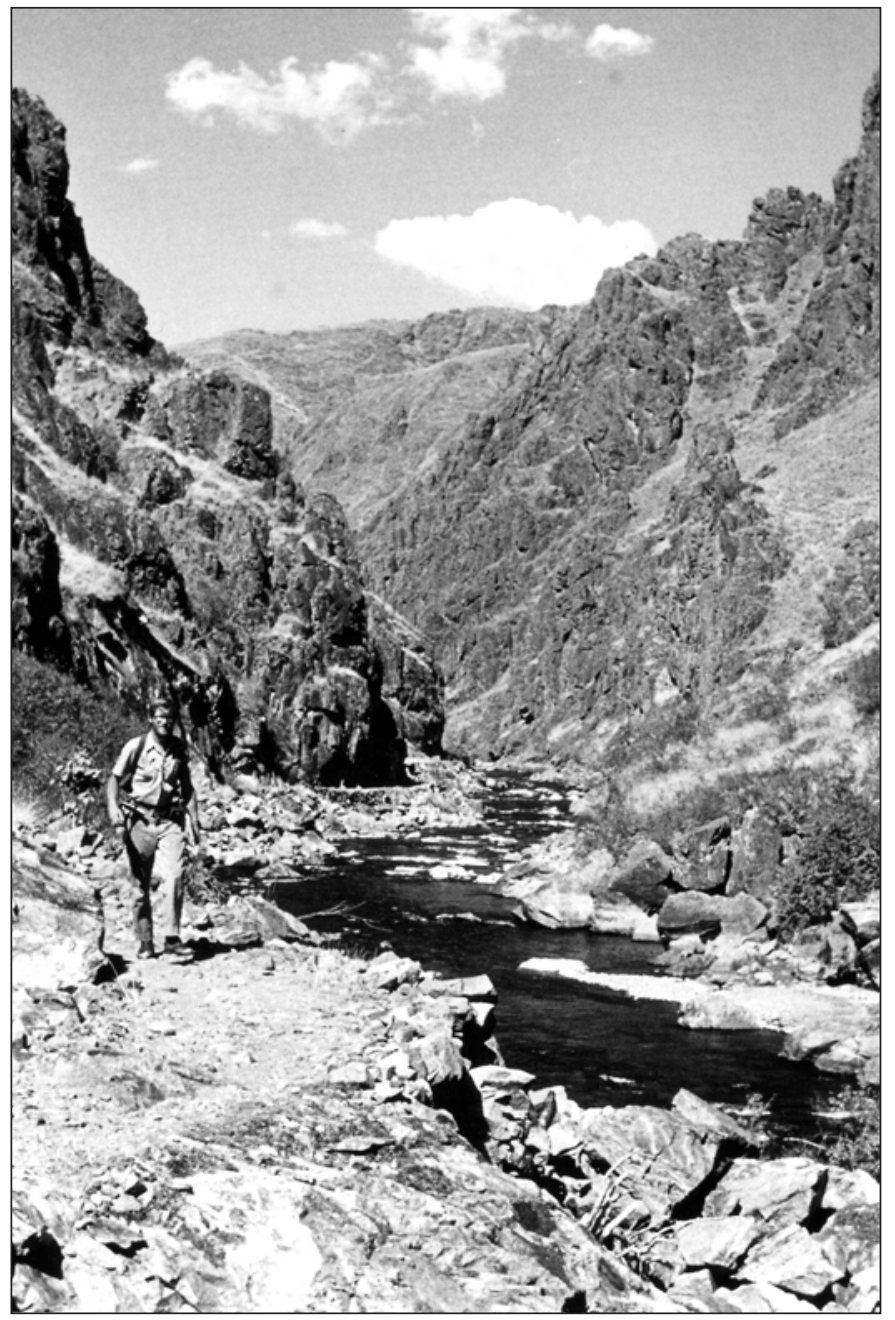

Figure 4. Aerial oblique view of the Seven Devils Mountains from northwest. Echo Lake, foreground; Triangle Lake, right, He Devil Lake, left; He Devil, 9,393 $\mathrm{ft}(2,863 \mathrm{~m})$, highest peak in the Seven Devils Mountains skyline. (Photograph taken August 27, 1976). 

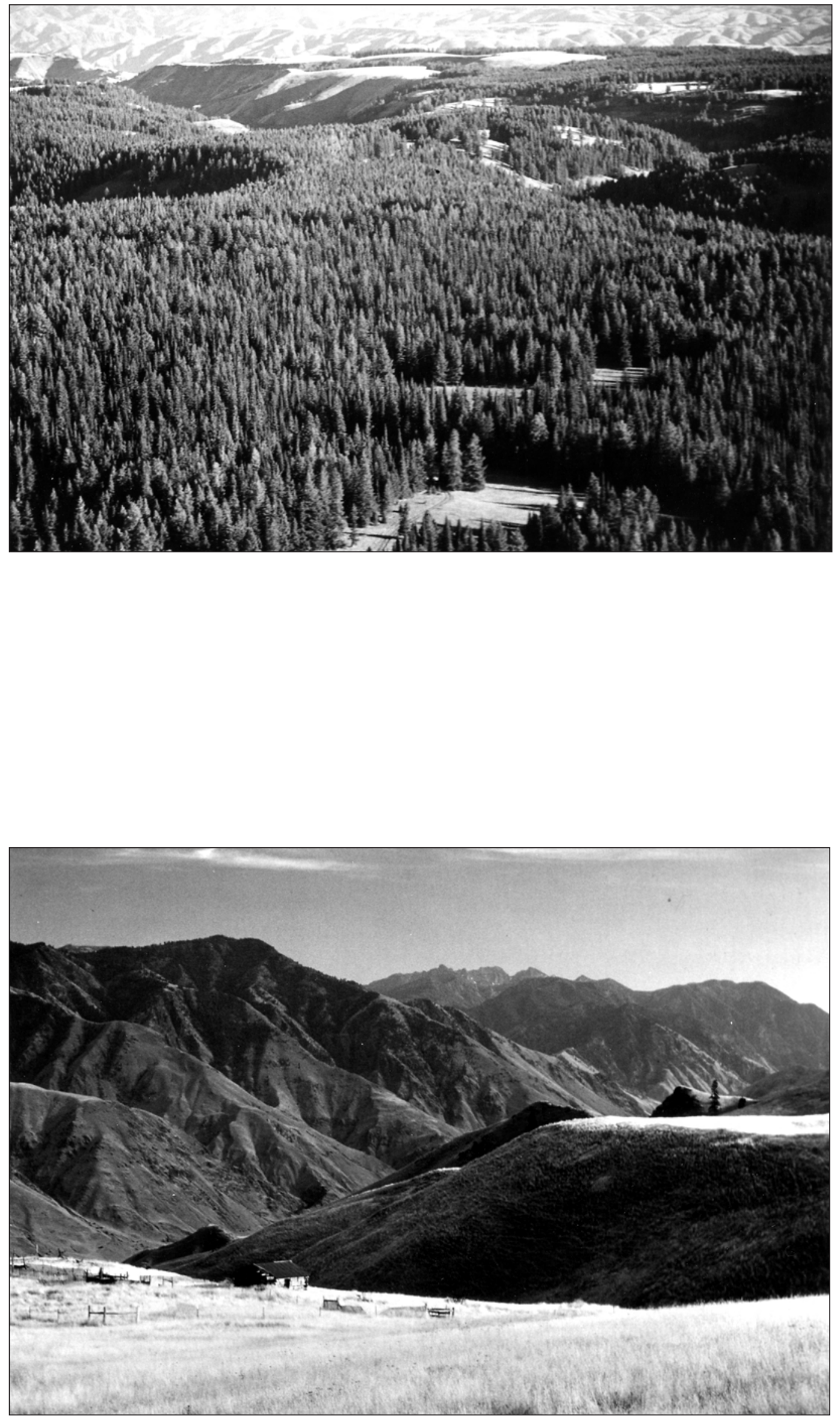

Figure 6. Aerial oblique view of plateau remnants with forests and meadows between Snake and Imnaha Rivers. (Photograph taken August 19, 1976).
Figure 7. Dissected midcanyon bench along Snake River between Two Corral and Sand Creeks, Oreg.; Seven Devils Mountains in background. (Photograph taken August 29, 1976). 


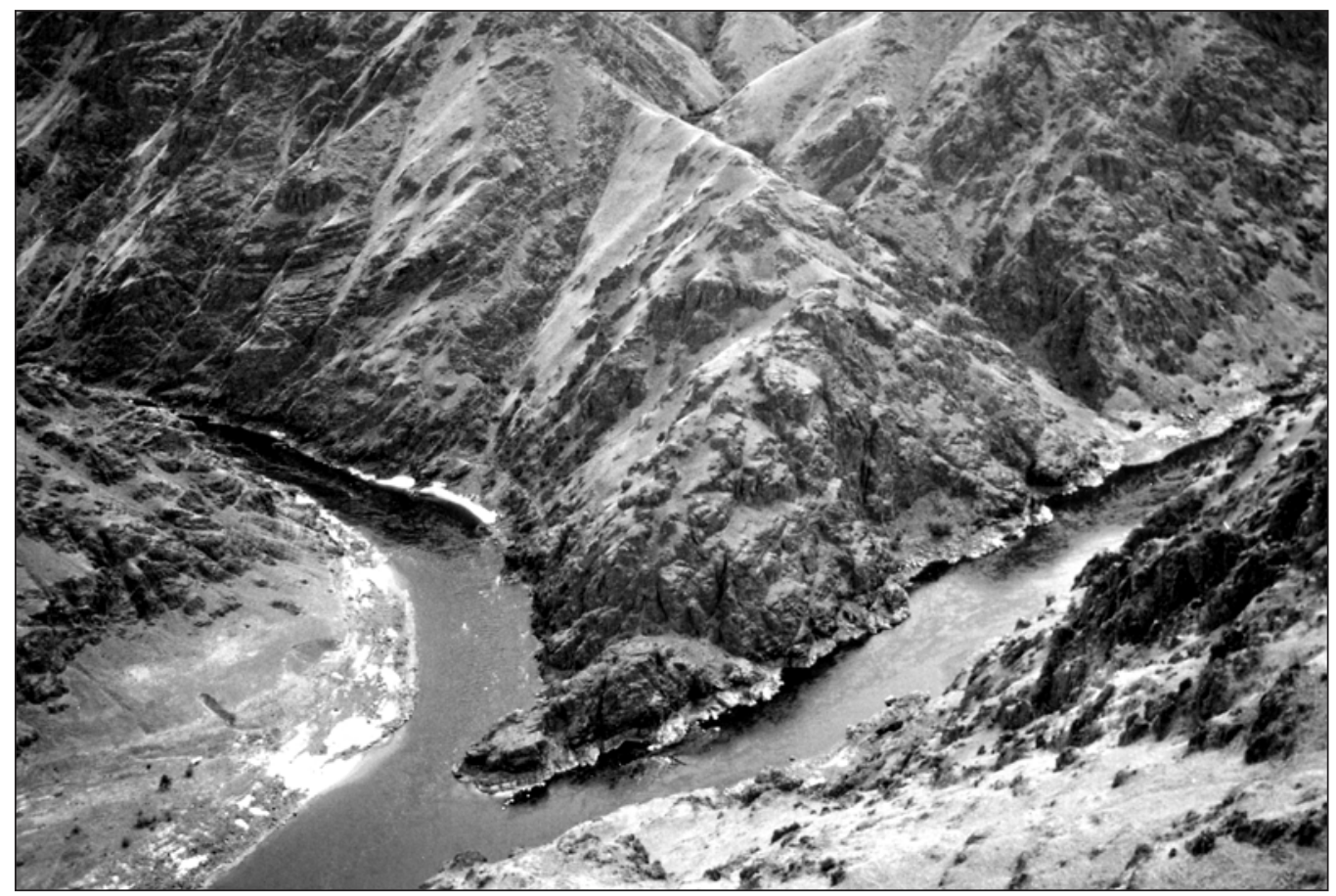

Figure 8. Confluence of Salmon River (left) and Snake River (right); air oblique view from westnorthwest. (Photograph taken August 18, 1976).

quail, and turkey. Anglers have the option of fishing in alpine lakes, a number of streams, Hells Canyon Reservoir, or the Snake and Imnaha Rivers; the most commonly caught fish are brook, cutthroat, and rainbow trout, smallmouth bass, perch, crappie, Dolly Varden, channel catfish, steelhead, Chinook salmon, and white sturgeon.

\section{Previous Investigations}

Hells Canyon has been of interest to geologists and mining engineers for many years, and geologic features of the area are described in many published reports. Lindgren (1900) sketched the geology of a large region that includes part of the study area, and Wagner (1945) made a reconnaissance geologic map of the east-central part of the study area near Pittsburg Landing. Ralph S. Cannon and co-workers studied the metavolcanic and plutonic rocks in the southern part of the study area; their work was summarized by Hamilton (1963b).

Hamilton (1963b, 1969) mapped most of the Riggins 30minute quadrangle, which includes the southeastern part of the study area. These investigations and others by Hamilton (1960, 1965) were concerned chiefly with foliated metamorphic and plutonic rocks that are extensively exposed to the east, and with Miocene basalt and Cenozoic structures (Hamilton, 1962, 1963a).

The geology of the southern part of the area was described in detail by Brooks and Vallier (1967), and the same authors (1978) later discussed the Mesozoic rocks and tectonic evolution of the entire region. Perhaps the most pertinent works from the point of view of this report are the mapping and stratigraphic studies by Vallier $(1973,1974,1977)$. Other papers concerning more specific features include those of Vallier and Fredley
(1972), Vallier and Miller (1974), Holden and Hooper (1976), and Vallier and Batiza (1978).

Early accounts of mineral deposits were published by Packard (1895), Lindgren (1899, 1900), Reed (1907), and Umpleby (1916), but the most comprehensive study was carried out by Livingston and Laney (1920). Cook (1954) made a similar study, and Libbey (1943) investigated the prospects near the confluence of the Snake and Imnaha Rivers.

Many of the more important studies concerning the Hells Canyon study area are unpublished papers, chiefly graduate theses. Among these are Morrison's (1963) study of pre-Tertiary geology between Cache Creek and Dug Bar, Valliers's (1967) investigation, which has been largely superseded by his later published papers, W. H. White's (1968) thesis regarding plutonic rocks in the Seven Devils Mountains, Ozier's (1971) study of the "Tertiary-Pretertiary unconformity," Morganti's (1972) research of ore deposits in the Seven Devils district, D.L. White's (1972) geology of the Pittsburg Landing area, Vallier and Hooper's (1976) guide to Hells Canyon, and Balcer's (1980) study of basement terranes.

\section{Present Investigation and Acknowledgments}

The purpose of this study is to evaluate the mineral potential of the Hells Canyon study area. Fieldwork by the U.S. Geological Survey consisted of reconnaissance mapping and geochemical sampling during August and September 1974 by George C. Simmons, James L. Gualtieri, Harry A. Waldrop, R. James Corken, and John G. Viets; during July, August, and September 1975 by Simmons, Gualtieri, James C. Ashleman, and Ronald J. Stein; during June, July, August, and September 1976 by Simmons, Ashleman, Darrell M. 
Pinckney, and Kim R. Perez; and during August and September 1979 by Simmons, David E. Balcer, Jeffrey J. Carapella, and Burton W. Coxe. In all, slightly more than two manyears were devoted to fieldwork.

The canyon of the Snake River was studied by means of a rubber raft expedition during the first field season. Foot traverses were made in tributary canyons, on some ridges, and along the canyon walls where possible. Access was provided by helicopter during the other field seasons, foot traverses being made between drop off and pick up points. Some of the work in Oregon was assisted by four-wheel-drive vehicles where roads permitted access to the study area.

Geologic observations were made and samples were collected along all traverse lines. Stream-sediment samples were collected from all major and many minor streams. Rock samples were collected along the crests and flanks of most ridges and in canyon bottoms, particularly in areas of altered rock and near mineral deposits. A few soil samples were taken where rocks appeared to have been hydrothermally altered, and a few water samples were taken from hot springs to test for geothermal reservoirs.

Rock, stream-sediment, and soil samples were analyzed in a mobile laboratory in the field and at laboratories in Denver, Colo., by chemists of the U.S. Geological Survey. Semiquantitative spectrochemical analyses were conducted by S.J. Sutley and Carl Forn; atomic absorption analyses by J.G. Viets and C.A. Curtis; colorimetric analyses by Viets, Sutley, D.E. Watford, and Ned Stevenson; and mercury detector tests by D.M. Hopkins, Viets, and Curtis. All samples were scanned for radioactivity, and equivalent uranium was tested by J.C. Negri. Water samples were analyzed at the Menlo Park, Calif., laboratory of the U.S. Geological Survey by J.M. Thompson, and the data were interpreted by R.O. Fournier. Analytical data were edited for computer storage and retrieval by S.K. McDanal, C.M. McDougal, R.J. Smith, W.S. Speckman, and T.M. Billings.

An airborne magnetometer survey was flown in 1974 by Geometrics, Inc., under contract to the U.S. Geological Survey, and a regional gravity survey was made by Dolores M. Kulik in 1976. The interpretation of the geophysical data by Don R. Mabey is a separate part of this report.

The Bureau of Mines examined all mines, prospects, and mineralized areas in the Hells Canyon study area during 1974, 1975, and 1976. The fieldwork was done by Terry J. Close, Francis E. Federspiel, and Andrew M. Leszcykowski, assisted by Eric Zahl, Michael McCulla, Donald Smith, Robin McCulloch, Philip Barrett, William Hudson, Thomas Mattern, Andrew Berg, Karen Sweetman, Jerry Olsen, Dennis Finn, James Rigby, Douglas Harby, Jeffery Wilson, and Ernest Tuchek. About four man-years were spent in the field. During the study, 114 lode prospects, as well as placers, were examined.

County, State, Federal, and private records and reports were used to determine the locations of mineral properties and areas. Claim owners and previous owners of mineral properties provided historical and geological data. Most prospects were mapped, and all were sampled. Two hundred sixty adits with a combined measured and calculated length of about 54,000 ft
$(16,500 \mathrm{~m})$ and more than 300 prospect pits, shafts, and trenches were examined.

About 900-lode and 270-placer samples were taken. Lode samples consisted of rock chips across mineralized structures, wallrock, and country rock, and grab samples from stockpiles and mine dumps. To determine the maximum values present, personnel took select samples from stockpiles or mine dumps. Placer samples were taken from 160 localities along the Snake River, 26 on Rapid River, and 17 on elevated placers; wherever possible, gravel on bedrock was sampled.

All samples were checked for radioactive and fluorescent minerals. Lode samples were fire assayed for gold and silver concentrations. The presence and concentrations of other metallic constituents were determined by atomic absorption, colorimetric, or spectrographic analyses. Selected placer samples and at least one sample from each mineralized structure or zone were analyzed by semiquantitative spectrographic methods. The spectrographic analyses are not shown on the sample tables.

Placer samples were concentrated in the field by panning or washing in a sluice box fitted with an undercurrent. The concentrates were further processed on a laboratory Wilfley table.

The wholehearted cooperation of the U.S. Forest Service greatly facilitated operations. Recognition is due to John L. Rodgers and Albert Oard, Forest Supervisors, Wallowa-Whitman National Forest, William Endt, Forest Supervisor, Payette National Forest, and Donald L. Biddison, Forest Supervisor, Nezperce National Forest. Assistance was rendered in the field by Roland M. Stoleson, District Ranger, Nezperce National Forest, Ray Evans, Don Miller, Ben Cottman, and Frank Olson, District Rangers, and Sander Anderson, Fire Control Officer, Wallowa-Whitman National Forest.

Special thanks are due to Ken Blanchard who piloted a Forest Service patrol boat and transported samples, supplies, and mail during the first field season, and to V. R. Simmons and others who assisted with first aid and an emergency evacuation in 1976.

C. Ronald Willden, consulting geologist, provided geochemical data from the vicinity of the Blue Jacket mine near Kirkwood Creek, and Thomas Gallagher, geologist for Texas Gulf, provided geologic data from the vicinity of the Red Ledge mine.

\section{Geology}

\section{Geologic Setting and History}

The Hells Canyon study area is along the junction of the Columbia Plateau and Northern Rocky Mountains physiographic provinces and contains physiographic and geologic features of both provinces. The area is underlain by rocks that may be divided into six principal lithologic assemblages: (1) foliated metamorphic rocks_-slate, schist, and gneiss, formed from rocks of unknown but possibly Paleozoic age, 
probably during the Cretaceous; (2) volcanic and volcaniclastic rocks of Permian and Triassic ages; (3) limestones of Triassic and possibly other ages; (4) argillic mudstone of Jurassic age; (5) plutonic rocks and related dikes and sills of Triassic to Cretaceous ages; and (6) basalt flows of Miocene age. In addition to these assemblages, there are cataclastic rocks, unconsolidated to slightly indurated gravel that locally underlies the basalt flows of Miocene age, and surficial deposits-moraines, terrace gravels, colluvium, and alluvium of Quaternary age.

Foliated metamorphic rocks - slate, schist, and gneissoccur along the east wall of the canyon of the Rapid River. These rocks are in plates of major thrust faults, and are part of a metamorphic terrane east of the study area, in the drainages of the Little Salmon River, and of the Salmon River north of Riggins, Idaho (Hamilton, 1969). Most of the metamorphic rocks were formed from volcanic or sedimentary rocks of unknown age (Hamilton, 1963b, p. 20, 23, 26, 34-35), and probably were metamorphosed during the Cretaceous (Hamilton, 1963b, p. 83-84).

Slightly metamorphosed volcanic and volcaniclastic rocks of Permian and Triassic ages crop out on the canyon walls of the Snake River, in the Seven Devils Mountains, north and south of the Seven Devils Mountains, on the west side of the upper Rapid River, and in isolated places along the Imnaha River. These rocks are regarded as part of an island arc (Vallier, 1974, p. 3) that is extensively exposed in eastern Oregon, east of the study area along the lower part of the Salmon River in Idaho, and in isolated areas north and northeast of the study area (Morrison, 1963, p. 20; Hamilton, 1963b, p. 6). The rocks are part of a large Jurassic orogen that may include rocks as distant as the Klamath Mountains in southwestern Oregon (Hamilton, 1963b, p. 84). They are probably present everywhere in the subsurface of the study area, whether concealed by rocks deposited on or thrust over them, only being absent where invaded by plutons.

Limestone of Triassic age occurs in large bodies and as layers and minor lenses in several parts of the study area. One large body is exposed in a down-faulted block on the benches and inner walls of Hells Canyon near the south end of the study area. Limestone of Triassic or possibly older age crops out on the west side and the crest of the ridge extending north from the Seven Devils Mountains, on the divide between the Snake and Salmon Rivers. Limestone is also exposed along the Rapid River in a belt that continues northeastward out of the study area at least $20 \mathrm{mi}(32 \mathrm{~km})$ (Hamilton, 1963b). Less extensive bodies of limestone are on Cannon Ball Mountain and on ridges to the north. The occurrences in Hells Canyon, along the Rapid River, and in the area of Cannon Ball Mountain are correlated with the Martin Bridge Limestone (Vallier, 1974, p. 7; Hamilton, 1963b, p. 9-10), which is present in the Wallowa Mountains of northeast Oregon, about $24 \mathrm{mi}(38 \mathrm{~km})$ west of the study area. These limestones may also be correlative with the limestone near the mouth of the Grande Ronde River, a few miles north of the study area in Washington (Vallier, 1974, p. 7), and the limestone on Mission Creek near Slickpoo, Idaho (Morrison, 1963, p. 20). Small lenses of limestone occur at many places in the Triassic volcanic rocks; collectively, they may have regional significance, but they have not been reported outside of the study area.

Argillic mudstone containing siltstone, sandstone, and conglomerate occurs near the north end of the study area and near Pittsburg Landing. The rocks were derived from a nonvolcanic, or at least a nonmafic volcanic source (Morrison, 1963, p. 53), and were deposited in Jurassic seas that inundated the region. Similar rocks of Jurassic age are present in central Oregon (Lupher, 1941, p. 259-265), and near Mineral, Idaho (Livingston, 1932, p. 33). The mudstone near Pittsburg Landing may be of the same age as that in central Oregon, whereas the mudstone near the north end of the study area may be slightly younger (Morrison, 1963, p. 60). In contrast, Jurassic rocks in the Wallowa Mountains, about $45 \mathrm{mi}(72 \mathrm{~km})$ from the study area, are older.

Plutonic rocks ranging in composition from quartz diorite and granodiorite through diorite and gabbro occur throughout the study area. The larger plutonic bodies, and in general the more felsic bodies, are concentrated in the southern part of the area. The rocks are Triassic to Cretaceous age. Their occurrence in Permian and Triassic volcanic rocks is similar to that of granitic plutons in eastern and southwestern Oregon, but with the difference that the plutons in the latter areas are less altered (Hamilton, 1963b, p. 84). Jurassic to Cretaceous plutons in the study area may be related to plutons of the same age that constitute the Wallowa and Idaho batholiths.

Basalt flows of Miocene age cover much of the northwestern part of the study area and form the rim of the canyon of the Snake River along most of its western side and part of its eastern side. The flows occur locally at river level near Dug Bar and as outliers on the east side of the canyon and in the Seven Devils Mountains. The flows are part of a vast province of tholeiitic basalt that extends over southeast and southcentral Washington, northeast, central, and east-central Oregon, and west-central Idaho. The flows are the product of many eruptions, closely spaced in time, and are derived from a common source.

The following summary of the geologic history of the study area is based chiefly on the observations of Vallier $(1967,1974)$ and Hamilton (1963b). The earliest event for which firm evidence exists occurred during the Permian when basalt and andesite flows and volcaniclastic rocks were deposited. While this deposition was taking place, the region to the west and southwest of the study area was uplifted. Prior to the Middle Triassic, the flows and volcaniclastic rocks were deformed and intruded by granitic and gabbroic plutons. Afterwards, flow rocks and volcaniclastic rocks were again deposited in a developing basin; beds of limestone were deposited in places temporarily unaffected by volcanism. Further subsidence and basin fragmentation took place concurrently with the deposition of volcanic and volcaniclastic rocks and the emplacement of gabbro and quartz diorite plutons into the Late Triassic. This was followed by the deposition of limestone, presumably throughout the study area. 
No layered rocks exist recording the span of time following the deposition of limestone until the Middle Jurassic, although such rocks are present a few tens of miles to the west and south near Huntington, Oreg. During this time the area was slightly uplifted and older rocks were eroded. In the Middle and Late Jurassic, black mudstone, preserved only in the northern part of the study area, was deposited on deformed rocks of Triassic age. Then, a major orogeny resulted in folding and faulting of pre-existing rocks, contemporaneous or penecontemporaneous metamorphism of volcanic and volcaniclastic rocks to greenstones, and the emplacement of granitic and gabbroic plutons.

In the Late Jurassic, probably the latest Late Jurassic, limestone and greenstone were thrust northwestward or westward into the eastern part of the study area. This event was followed in the Early Cretaceous by the intrusion of granitic plutons at the south end of the study area and elsewhere. Later in the Early Cretaceous, low- to high-grade metamorphism, most effective east of the study area, transformed volcanic and sedimentary rocks into slate, marble, schist, and gneiss. Shortly thereafter westward thrusting moved the foliated metamorphic rocks into the southeastern part of the study area.

A hiatus marks the period from later Early Cretaceous to middle Miocene time. The region was uplifted and an erosion surface of generally low but mixed relief developed; mountains probably existed in the southeast part of the study area and a few canyons were present in the north. Then, in the middle Miocene, basalt erupted from numerous fissures and spread over the erosion surface, inundating all older rocks with the possible exception of the peaks in the south. During the late Miocene and Pliocene, the region was subjected to warping and block faulting, although these features are not as prominent in the study area as elsewhere. In latest Pliocene or Pleistocene time and prior to Wisconsin glaciation, Hells Canyon was eroded to nearly its present depth.

During the Pleistocene, the mountainous, southern part of the study area was glaciated, producing morainal deposits; some older gravels were probably deposited then also. During the Holocene, alluvium was deposited along the Snake River and its tributaries and colluvium or landslide debris was deposited at a few places.

\section{Metamorphic Rocks (Pzsg)}

Foliated metamorphic rocks crop out in an area of about $25 \mathrm{mi}^{2}\left(65 \mathrm{~km}^{2}\right)$ on the east side of the Rapid River in the southeastern part of the study area (pl. 1). The rocks are in the western fringe of a broad, north-trending belt of low- to highgrade metamorphic rocks along the Little Salmon and Salmon Rivers (Hamilton, 1963b). The terrane of metamorphic rocks is bounded on the west and separated from underlying limestone by a thrust fault. Within the metamorphic terrane, schistose rocks to the west constitute a lower thrust plate that is structurally separated from an upper plate of gneissic and migmatic rocks by another thrust fault that is subparallel to the basal thrust fault.
The rocks in the lower plate consist mostly of schists with minor meta-limestone, gneiss, and phyllite, whereas the rocks in the upper plate consist mostly of gneisses with minor meta-limestone and schist. The schists are composed of quartz, sericite, biotite, and chlorite with or without accessory amphibole, plagioclase, and garnet. The gneisses consist of quartz, plagioclase, amphibole, and biotite with or without accessory muscovite, chlorite, epidote, and garnet.

Quartz-sericite-chlorite and quartz-sericite-biotite schists are the most abundant, but some schists are composed almost entirely of quartz, sericite, or chlorite. Lighter colored quartzsericite and chlorite-bearing schists are concentrated to some extent in the lower part of the lower plate, and darker-colored biotite-bearing schists in the upper part of the lower plate. Amphibole-bearing schists were seen only in the upper part of the lower plate near North Star Butte (pl. 1). Most dark schist in the lower part of the lower plate contains graphite.

The gneissic rocks are fine to coarse grained and strongly to weakly foliated. All contain quartz and plagioclase as well as amphibole or biotite or both minerals. Where foliation is well developed, biotite- or amphibole-rich layers about an inch (several centimeters) thick alternate with quartz-plagioclaserich layers of equal or slightly greater thickness in undulating and locally isoclinally folded bands. Where the folia are greatly deformed, the gneiss shows evidence of mobilization; mafic layers were disrupted and now consist of fragments enveloped in felsic rock. Some coarse-grained gneiss containing sparse but aligned flakes of biotite may be parts of small intrusive bodies of trondhjemite that underwent slight metamorphism (Hamilton, 1963b, p. 67-68).

The thickness of the foliated metamorphic rocks is unknown. Repetition of layers by isoclinal folding, possible repetition by thrust faulting, and the possible equivalence of rocks of different metamorphic grades preclude any accurate determination of thickness without detailed geologic mapping. The rocks are presumed to be Paleozoic in age, but no fossils have been found, and the rocks do not resemble nearby Permian and Triassic rocks to the west or Precambrian rocks some distance to the east. East of the study area the metamorphic rocks are intruded by the Idaho batholith of middle Cretaceous age (Hamilton, 1963b, p. 35); so they could theoretically be of any age from Precambrian to Cretaceous.

\section{Cataclastic Rocks}

\section{Mylonite and Intensely Sheared Rocks (myd)}

A complex zone of sheared rocks crops out in a northeasttrending band $13 \mathrm{mi}$ long $(21 \mathrm{~km})$ and 1 to $3 \mathrm{mi}$ wide (1.6 to 4.8 $\mathrm{km})$, crossing the canyon of the Snake River between Temperance Creek and Kurry and Klopton Creeks (pl. 2). At both ends this zone disappears beneath the Columbia River Basalt Group. More than half of the rocks in this shear zone were derived from basalt flows, breccias, and other rocks in the Seven Devils Group. Most of the volcanic rocks are strongly foliated, but 
some rock, from fist-size pieces to areas covering as much as $0.25 \mathrm{mi}^{2}\left(0.65 \mathrm{~km}^{2}\right)$ are unfoliated or only weakly foliated; volcanic rocks, especially the breccias, can be recognized in complete sequences from unfoliated to schistose rocks.

The sheared rocks were intruded by dikes, sills, and small plutonic bodies of diorite and some gabbro. Most but not all of these rocks are also strongly foliated, and a complete range from unfoliated diorite to diorite gneiss to gneissic mylonite is also present. All these rocks have been intruded by dikes, sills, and plutons of granodiorite and quartz diorite. These granitic rocks too range from unfoliated to strongly foliated, but overall are not nearly so strongly foliated as their host rocks.

In addition, the zone contains amphibole, biotite, and chlorite schists, and mylonite. Some schists and mylonite were undoubtedly derived from the Seven Devils Group and the intrusive rocks, but it is possible, as suggested by Vallier and Hooper (1976, p. 28) and Balcer (1980), that some are basement rocks older than the Seven Devils Group.

A zone of highly sheared rocks crops out for about $2 \mathrm{mi}$ $(3.2 \mathrm{~km})$ along the Snake River between Dug Bar and the mouth of the Imnaha River. The zone is about 2,000 ft (610 m) wide on the Oregon side of the river where its vertical foliation strikes $\mathrm{N} .75^{\circ} \mathrm{W}$; t the part of the zone on the north side of the river in Idaho is outside of the study area and was not mapped. The rocks in this zone were discussed by Morrison (1963, p. 28-29), Vallier and Hooper (1976, p. 5-6), and Balcer (1980), all of whom considered them to be older than the Seven Devils Group. The rocks consist of interlayered light- and darkgray, fine-grained amphibole schist, chlorite-quartz schist, and protomylonite. These rocks were intruded by dikes and sills of diorite, quartz diorite, and gabbro that resemble the plutonic rocks near the mouth of the Imnaha River. Some of the chlorite schist resembles schist derived by shearing of metavolcanic rocks in the Seven Devils Group, but lacks the distorted breccia fragments found in many such rocks. The intrusive diorite ranges in structure from unfoliated to strongly foliated and intensely sheared.

\section{Mylonite and Intensely Sheared Rocks (my)}

Mylonite, protomylonite, and intensely sheared rocks occur near Haley Ridge and near White Mountain (pl. 1), on the east side of Cannon Ball Mountain (pl. 1), along the ridge crest north of Heavens Gate and south of Spring Mountain (pls. 1 and 2), opposite the mouth of Temperance Creek in Hells Canyon (pl. 2), and between Dug Bar and the mouth of the Imnaha River along the Snake River (pl. 2). These rocks were produced by dynamic metamorphism along vertical faults, in shear zones, and along thrust faults, and some of them are similar to the mylonite and other rocks (myd) in Temperance, Kurry, and Klopton Creeks.

The rock at Haley Ridge crops out in a thin lens-shaped area, $600 \mathrm{ft}(183 \mathrm{~m})$ in maximum width and $2 \mathrm{mi}(3.2 \mathrm{~km})$ long, along a vertical fault striking $\mathrm{N} .25^{\circ} \mathrm{E}$. The rock consists almost entirely of chlorite-quartz schist and foliated metabasalt. The interlayering of the schist and the metabasalt and the location of the fault within rocks of the Seven Devils Group leave little doubt that the schists were derived by shearing of metavolcanic rocks in that group.

A zone of weakly to strongly foliated greenstone, greenstone schist, mylonite, protomylonite, and amphibole schist occurs in a shear zone 4 mi long $(6.4 \mathrm{~km})$ and as much as $3,000 \mathrm{ft}$ wide $(914 \mathrm{~m})$ trending N. $36^{\circ}$ E. from the south side of White Mountain through Satan Lake into the valley of Paradise Creek; the mylonite was previously described by W.H. White (1968, p. 11-15). Much of the foliated greenstone and some of the protomylonite, particularly that containing distorted volcanic breccia fragments, are metavolcanic rocks of the Seven Devils Group. The mylonite is banded in alternating light- and dark-gray layers from a few inches to a few feet thick. The rocks are very fine grained and siliceous. The light-gray layers contain a few porphyroblasts of quartz and saussuritized feldspar, and at least some of the dark-gray layers contain streaks of hornblende.

The intensely sheared rocks on the northeast side of Cannon Ball Mountain occur along a thrust fault in a northwest-trending zone $1 \mathrm{mi}$ long $(1.6 \mathrm{~km})$ and as much as $800 \mathrm{ft}$ wide $(244 \mathrm{~m})$. The rocks are siliceous chlorite-sericite schists; because similar rocks have been produced elsewhere in the study area by the shearing of metavolcanic rocks of the Seven Devils Group, it seems likely that such is the case at Cannon Ball Mountain, although no recognizable rocks of the Seven Devils Group were found within the schists.

The sheared rocks along the ridge north of Heavens Gate are in a narrow, 10-mi-long $(16 \mathrm{~km})$ zone that is interrupted at two places by layers of foliated limestone. The rocks consist mostly of chlorite schist and strongly to weakly foliated metavolcanic rocks of the Seven Devils Group with minor amphibole schist. At many places the band contains metavolcanic breccias in which the breccia fragments have been distorted by shearing.

In all but the north part of the band, the zone of shearing is subparallel to and about 1,000 ft (305 m) above an east-dipping thrust fault, but the shear zone is not believed to represent a significant displacement because toward its north end it abuts layers of limestone that although foliated are not offset. At the north end of the band, the surface of the thrust fault approaches the shear zone, and sheared metavolcanic rocks along the thrust fault merge with and become indistinguishable from metavolcanic rocks in the shear zone. The few amphibole schists in the shear zone almost certainly were derived from metavolcanic rocks of the Seven Devils Group, and it seems likely that some amphibole schists in other shear zones could have a similar origin.

The sheared rocks in Hells Canyon opposite the mouth of Temperance Creek consist of chlorite schist and interlayered, foliated metavolcanic rocks of the Seven Devils Group in a 4,000-foot-long $(1,200 \mathrm{~m})$ zone as much as $1,600 \mathrm{ft}(490 \mathrm{~m})$ wide, trending $\mathrm{N} .75^{\circ} \mathrm{E}$. The zone is $1,500 \mathrm{ft}(460 \mathrm{~m})$ south of the large zone of mylonite and foliated and schistose rocks (myd), and may be related to that zone. However, the rocks are less intensely sheared and seem to be entirely derived from rocks of the Seven Devils Group. 


\section{Seven Devils Group ( KPs)}

The metavolcanic rocks in Hells Canyon and the Seven Devils Mountains were named the Seven Devils Volcanics by Anderson (1930) and were redesignated the Seven Devils Group by Vallier (1974). As defined by Vallier, the Seven Devils Group consists of four formations, the upper three (in ascending order, the Hunsaker Creek, Wild Sheep Creek, and Doyle Creek Formations) occur in the study area. Although the authors recognize the general lithologic sequence of the Seven Devils Group as described by Vallier, the mutual contacts of the Hunsaker Creek, Wild Sheep Creek, and the Doyle Creek Formations are not defined, and with the exception of the Upper Triassic Kurry Creek Member of the Doyle Creek Formation, the Seven Devils Group was mapped as an undivided unit.

The Seven Devils Group is the most widely distributed of all of the pre-Miocene rocks. It is extensively exposed along the canyon of the Snake River from the southern part of the study area to Temperance Creek (pls. 1 and 2), from Davis to Lonepine Creeks (pl. 2), and from Knight to Coon Creeks (pl. 2); in the Seven Devils Mountains (pl. 1); and in the drainage of the Rapid River on its west side (pl. 1). The group is locally overlain by the Martin Bridge Limestone in the south (pl. 1), by the Coon Hollow Formation in the north (pl. 2), and by limestone of Triassic age that was thrust over the group near the east margin of the study area (pl. 1). The group is intruded by numerous plutons, but nonetheless is undoubtedly the most abundant rock unit underlying the Columbia River Basalt Group that blankets much of the area.

The Seven Devils Group is composed of a variety of volcanic flow rocks, volcaniclastic (pyroclastic and epiclastic) rocks, and limestone, most of which were deposited in marine environments, and much of which were subsequently metamorphosed to greenstones. Mixed rock types occur locally where volcanic ejecta became imbedded in limey matrices.

The flow rocks are chiefly basalt, basaltic andesite, and andesite, generally the soda-rich varieties, spilite and keratophyre; felsic flows, dacite, latite, trachyte, and rhyolite are rare. Flow structure was observed at only a few places, and pillow structures were not positively identified. Vesicles are uncommon, and where present are usually small and contain amygdules of calcite. Individual flows are from 1 to $200 \mathrm{ft}(0.3$ to $61 \mathrm{~m}$ ) thick.

The pyroclastic rocks are also chiefly basalt, basaltic andesite, and andesite, occurring as breccia, breccia-tuff, and crystal and lapilli tuff, all of which types intergrade. Breccia fragments are angular, blocky, pebble- to cobble-size ejecta that either compose entire units, or more commonly are enclosed in a matrix of fine fragments or crystal tuff. Lapilli are mostly small, rounded, pebble-size ejecta that may also make up entire layers, but are generally embedded in crystal tuff. The crystal tuff is mostly plagioclase and chlorite (metamorphosed pyroxene), contains pumice fragments, lithic fragments, and devitrified glass, and for the most part is poorly sorted. The pyroclastic rocks are interlayered with flow rocks and epiclastic rocks and occur in units from 1 to $100 \mathrm{ft}$ ( 0.3 to 31 m) thick.

Epiclastic rocks include breccia, conglomerate, graywacke, sandstone, siltstone, and argillite. Breccias are poorly sorted and contain pebble- to cobble-size fragments in a matrix of sand and silt. The conglomerates contain rounded cobbles and pebbles, chiefly of volcanic rocks, but also of granitic rocks and limestone. Graywackes contain clasts of feldspar, volcanic rocks, and quartz, and commonly a few pebbles of volcanic rocks in a matrix of clay and silt; the graywackes are poorly graded and gently crossbedded at many places. Siltstone and argillite are interbedded with graywacke and conglomerate, and are undoubtedly similar in origin. The breccia and conglomerate occur in units from 1 to $35 \mathrm{ft}(0.3$ to $11 \mathrm{~m}$ ) thick, whereas the graywacke, siltstone, and argillaceous rocks are seldom in units more than $10 \mathrm{ft}(3 \mathrm{~m})$ thick.

The colors of the flow and volcaniclastic rocks are somewhat indicative of rock compositions, the more basic rocks having darker colors (rock color indexes in parentheses). Surfaces of freshly fractured basalts are greenish black (5GY 2/1, 5G 2/1), brownish black (5YR 2/1), dark greenish gray (5GY 4/1, 5G 4/1), and dusky yellowish green (10GY 3/2); the same rocks weather dark yellowish brown (10YR 4/2), dusky brown (5YR 2/2), moderate yellowish brown (10YR 5/4), and moderate brown (5YR 4/4, 5YR 3/4). Locally, the surfaces of freshly broken basalts are dusky red (5R 3/4) and very dusky red (10R 2/2); these rocks weather pale reddish brown (10R 5/4) and moderate yellowish brown (10YR 5/4).

The colors of andesites are noticeably lighter than those of basalts. Unweathered andesites are grayish green (10GY $5 / 2$ ), pale green ( $5 \mathrm{G} 7 / 2)$, grayish olive (10Y $4 / 2)$, dusky yellow green (5GY 5/2), brownish gray (5YR 4/1), and light green (5G 7/4); the weathered andesites are pale yellowish brown (10YR 6/2), light brown (5YR 5/6, 5YR 6/4), pale brown (5YR 5/2), moderate yellowish brown (10YR 5/4), and light olive brown (5Y 5/6).

The colors of the epiclastic rocks resemble those of the andesites: grayish olive (10Y 4/2), greenish gray (5GY 6/1, 5G $6 / 1$ ), light greenish gray (5GY 8/1, 5G 8/1), and light green (5G 7/4); the epiclastic rocks weather pale yellowish brown (10YR 6/2), light brown (5YR 6/4, 5YR 5/6), light olive brown (5Y 5/6), moderate yellowish brown (10YR 5/4), dark yellowish brown (10YR 4/2), and pale brown (5YR 5/2). A few of the epiclastic rocks are dusky red (5R 3/4) and grayish red (10R 4/2), and weather pale reddish brown (10R 5/4).

The mineralogy of the volcanic rocks indicates that they have been subjected to low-grade metamorphism. Minerals observed in thin sections are albite, oligoclase, chlorite, epidote, calcite, quartz, sphene, leucocene, sericite, actinolite, and prehnite, as well as some of the original calcic plagioclases and pyroxenes. Most of the original plagioclase is saussuritized and partly replaced by albite and oligoclase, and most of the original mafic minerals, chiefly pyroxenes, are replaced by chlorite. Vallier (1974, p. 11) observed that metamorphism is more complete in the older part of the group than in the 
younger, and relates the difference to depths of burial and consequent differences in proximity to heat sources.

Limestone makes up only a small part of the Seven Devils Group, but it is widespread in horizontal and stratigraphic distributions. It commonly occurs in layers that are only a few feet thick, but in places crops out in lenses more than $100 \mathrm{ft}$ $(31 \mathrm{~m})$ thick and $0.5 \mathrm{mi}(0.8 \mathrm{~km})$ long. The rock is usually fine grained to sublithographic. Unweathered limestone is dark gray, or greenish gray where it contains abundant argillaceous material, and weathers to shades of light gray that are locally tinted by traces of iron oxide. Bedding is massive to thin, the latter being particularly apparent where the limestone is interlaminated with argillite. Much of the limestone yields a fetid odor when struck with a pick, and poorly preserved fossils, mostly clams and brachiopods, are present at many places.

Although the Seven Devils Group is not divided in this report, lithologic assemblages assigned to specific formations by Vallier (1977) were recognized. The lowest stratigraphic part of the group within the study area, the Lower Permian Hunsaker Creek Formation of Vallier, is identified by its abundance of tuff and epiclastic rocks: conglomerate, graywacke, siltstone, and breccia. This assemblage is restricted to the southern part of the study area on the ridge east of Hells Canyon Reservoir in Idaho (pl. 1).

By far the greatest part of the Seven Devils Group is assigned to the Middle and Upper Triassic Wild Sheep Creek Formation (Vallier, 1977), which is widespread throughout the pre-Miocene rocks in the study area. The Wild Sheep Creek contains an abundance of lithologic rock types, but is characterized chiefly by thick basalt flows, and at its top by a concentration of clastic rocks and to a lesser extent by limestone.

The upper part of the group, the Upper Triassic Doyle Creek Formation (Vallier, 1977), is identified by its concentration of reddish volcaniclastic rocks. These rocks are most abundant high on the Oregon side of the canyon of the Snake River, just under the Columbia River Basalt Group, from the headwaters of Spring Creek to Black Mountain (pl. 1), and in the upper parts of Downey and Cook Creeks (pl. 2).

The thickness of the Seven Devils Group is unknown; structural complexities within and between formations preclude accurate estimates. Observed cumulative thicknesses (Vallier, 1973) in the study area are near 24,600 ft (7,500 m), and the true thickness is probably considerably greater.

The Seven Devils Group within the study area ranges in age from Early Permian to Late Triassic. Limestones are neither abundantly fossiliferous nor are the faunas well preserved; nevertheless, the faunas are sufficiently diagnostic that parts of the group can be dated. Vallier (1977, p. 26) recorded a brachiopod fauna of Early Permian age from the Hunsaker Creek Formation, and clams and ammonites indicating Middle and Late Triassic ages, respectively, for limestones in the Wild Sheep Creek Formation. Clams and brachiopods of Middle to Late Triassic ages were collected from the Wild Sheep Creek Formation at four places during the present study (table 1) (J.T. Dutro, written commun., 1974; K.M. Nichols and N.J. Silberling, written commun., 1975).

\section{Kurry Creek Member of the Doyle Creek Formation (Rsk)}

The Kurry Creek Member of the Doyle Creek Formation is a distinctive lithologic unit of limited distribution, occurring on both sides of the Snake River in a northeast-trending band, about $3 \mathrm{mi}(5 \mathrm{~km})$ long and $2 \mathrm{mi}(3 \mathrm{~km})$ wide, in the vicinity of Pittsburg Landing (pl. 2). At the northeast and southwest ends of the band, the Kurry Creek Member is covered by the Columbia River Basalt Group; the southeast margin of the belt is a high-angle reverse fault or a thrust fault; and to the northwest the member conformably or perhaps disconformably overlies older rocks in the Seven Devils Group.

The Kurry Creek Member is composed chiefly of clastic rocks, but also contains tuffs, flows, and limestone. The sequence was originally named the Pittsburg Formation by Wagner (1945) who considered it of Carboniferous age. However, a Late Triassic marine fauna was discovered in the limestone beds, and Vallier (1977, p. 45-48) renamed the unit and reduced it to member rank in the upper part of the Doyle Creek Formation.

Conglomerates are dusky brown (5YR 2/2) to grayish green (10GY 5/2, 5G 5/2) and weather pale brown (5YR 5/2) to pale yellowish brown (10YR 6/2), and contain angular to well-rounded pebbles, cobbles, and boulders of volcanic rocks as much as $2 \mathrm{ft}(0.6 \mathrm{~m})$ in diameter. Pebbles of plutonic rocks are sparsely intermingled among the volcanic clasts, and all are imbedded in a matrix of graywacke. Conglomerates grade into graywackes and occur in distinct units from 10 to $100 \mathrm{ft}$ ( 3 to $31 \mathrm{~m}$ ) thick, but layering within the units is rare.

Most sandstones are fine- to medium-grained graywackes containing subangular to subrounded grains of plagioclase, quartz, and lithic fragments, and at places a few pebbles of volcanic rocks and carbonized plant remains. Freshly fractured graywackes are greenish black (5GY 2/1, 5G 2/1) and dusky brown (5YR 2/2), and weather dusky yellow brown (10YR 2/2), pale brown (5YR 5/2), and pale yellowish brown (10YR 6/2). Bedding is poorly developed, but where present is generally $1-2$ in. $(2.5-5 \mathrm{~cm})$ thick. Graywacke grades into siltstones and argillaceous rocks, but the latter two are poorly exposed, being less resistant to weathering than the arenaceous rocks.

Basaltic and andesitic tuffs, flows, and flow breccias, similar to those in other parts of the Seven Devils Group, make up a small part of the Kurry Creek Member. Flows are generally between 10 and $100 \mathrm{ft}$ ( 3 and $31 \mathrm{~m}$ ) thick, and the tuff units are rarely more than $10 \mathrm{ft}(3 \mathrm{~m})$ thick.

Limestone is distributed sparingly in the Kurry Creek Member, commonly in units less than $3 \mathrm{ft}(1 \mathrm{~m})$ thick. The rock is fine grained and thin bedded, in layers that are 0.5 to 2 in. (1 to $5 \mathrm{~cm}$ ) thick. It is also argillaceous and silty, and grades into argillaceous rocks and siltstone. These rocks contain ammonites, pelecypods, and abundant, poorly preserved and carbonized plant remains.

With the exception of some rocks east and northeast of the Circle C Ranch, the Kurry Creek Member is weakly 
metamorphosed, obviously less than older parts of the Seven Devils Group. Albite, chlorite, epidote, and calcite were recognized by Vallier $(1974$, p. 6) as replacements of original minerals. Calcite veinlets occur sparsely to abundantly in some conglomerate and graywacke units.

The preserved thickness of the Kurry Creek Member is only roughly estimated. The member is much deformed by folding and offset by thrust faults along its southeast margin, but at its northwest margin it dips moderately and consistently to the south, and has a mapped thickness of more than $3,300 \mathrm{ft}$ $(1,000 \mathrm{~m})$.

\section{Limestone Inclusions in Granitic Rocks ( $\mathrm{RPIt}$ )}

Small bodies of limestone occur as inclusions in granodiorite and quartz diorite, most notably near White Monument and Pepperbox Hill (pl. 1). The largest of these inclusions, at the southwest end of White Monument near Lockwood Sad$\mathrm{dle}$, is about 2,600 ft (790 m) long and $500 \mathrm{ft}(150 \mathrm{~m})$ wide.
Most of the limestone has been metamorphosed to a very light gray (N8), coarsely crystalline marble, and some, particularly near its contact with the granitic rocks, has been converted into garnet-epidote-pyroxene tactite. Some of the smaller inclusions have been almost completely transformed into tactite. The unmetamorphosed limestone is light gray (N7) to light bluish gray (5B 7/1), fine grained, and contains a few thin argillaceous and sandy laminae. The latter rock is commonly slightly siliceous and at places grades into tactite.

The age of the limestone inclusions is uncertain, but it is suspected that they are Late Triassic, and more likely derived from the Seven Devils Group than from the Martin Bridge Limestone. This supposition is based on the presence of partly metamorphosed volcanic rocks from the Seven Devils Group adjacent to a few of the limestone inclusions, the proximity of the Seven Devils Group to the inclusions, and the probability that tactite is more likely to develop from impure limestones such as occur in the Seven Devils Group than from the more pure limestone of the Martin Bridge Limestone.

Table 1. Fossil collections from limestones in the Seven Devils Group (Wild Sheep Creek Formation).

[Collection numbers, grid coordinates, and plate numbers are from Simmons and others (1984). Faunal identifications by J.T. Dutro, K.M. Nichols, and N.J. Silberling]

\begin{tabular}{|c|c|c|c|}
\hline $\begin{array}{c}\text { Collection no. } \\
\text { (Grid coordinates) }\end{array}$ & Locality & Fauna & Age \\
\hline $\begin{array}{l}\text { HC 0341 } \\
(\mathrm{X} 19-\mathrm{Y} 45) \\
\text { plate } 4 .\end{array}$ & $\begin{array}{l}\text { lat } 45^{\circ} 56^{\prime} 38^{\prime N} \mathrm{~N} ., \\
\text { long } 116^{\circ} 52^{\prime} 55^{\prime \prime E} \text {. } \\
\text { On ridge crest on } \\
\text { north side of Coon } \\
\text { Creek. }\end{array}$ & Spondylospira. & $\begin{array}{l}\text { Most likely Late } \\
\text { Triassic: Norian. }\end{array}$ \\
\hline $\begin{array}{l}\text { HG } 0139 \\
\text { (X25-Y24) } \\
\text { plate } 2 .\end{array}$ & $\begin{array}{l}\text { lat } 45^{\circ} 22^{\prime} 02^{\prime N} \text {., } \\
\text { long } 116^{\circ} 38^{\prime} 45^{\prime \prime} \mathrm{E} . \\
\text { On Snake River } \\
\text { trail, about } 0.6 \mathrm{mi} \\
(1 \mathrm{~km}) \text { north of } \\
\text { Cache Creek. }\end{array}$ & $\begin{array}{l}\text { Traces of halobiid } \\
\text { ribbing? fish teeth. }\end{array}$ & $\begin{array}{l}\text { Late Middle to Late } \\
\text { Triassic. }\end{array}$ \\
\hline $\begin{array}{l}\text { HG } 0142 \\
\text { (X25-Y24) } \\
\text { plate } 2 .\end{array}$ & $\begin{array}{l}\text { lat } 45^{\circ} 23^{\prime} 19^{\prime \prime} \mathrm{N} . \\
\text { long } 116^{\circ} 37^{\prime} 56^{\prime} \mathrm{E} \text {. } \\
\text { On Snake River } \\
\text { trail, } 700 \mathrm{ft}(200 \mathrm{~m}) \\
\text { above bed of Saddle } \\
\text { Creek. }\end{array}$ & $\begin{array}{l}\text { Daonella degeeri or } \\
\text { Halobia cf. } \\
\text { H. halorica. or } \\
\text { middle Norian. }\end{array}$ & $\begin{array}{l}\text { Late Middle Triassic: } \\
\text { late Ladinian or late } \\
\text { Late Triassic: early }\end{array}$ \\
\hline $\begin{array}{l}\text { HS } 0312 \\
\text { (X28-Y37) } \\
\text { plate } 3 .\end{array}$ & $\begin{array}{l}\text { lat } 45^{\circ} 43^{\prime} 29^{\prime \prime} \mathrm{N} ., \\
\text { long } 116^{\circ} 32^{\prime} 31^{\prime \prime E} \text {. } \\
\text { About } 50 \mathrm{ft}(15 \mathrm{~m}) \\
\text { below and on south } \\
\text { side of minor ridge } \\
\text { on north side of } \\
\text { Lonepine Creek. }\end{array}$ & $\begin{array}{l}\text { Halobia of the } H \text {. } \\
\text { ornatis-sima group. }\end{array}$ & $\begin{array}{l}\text { Middle Late Triassic: } \\
\text { late Karnian or } \\
\text { possibly early } \\
\text { Norian. }\end{array}$ \\
\hline
\end{tabular}




\section{Sheared Limestone (KPIs)}

Several bodies of limestone similar to the Martin Bridge Limestone, but which may have different stratigraphic positions, were mapped near the east boundary in the south part of the study area. These limestones crop out in narrow 9-mi-long (14 km) and 2-mi-long (3 km) bands in the drainage of Sheep Creek on the west side of the ridge dividing drainages of the Snake and Salmon Rivers (pl. 2), in an area of about $2 \mathrm{mi}^{2}$ on the east side of Cannon Ball Mountain (pl. 1), and in a 16-milong $(26 \mathrm{~km}$ ) band along the Rapid River (pl. 1). All of these bodies have structurally complex relations with adjacent rocks; they are thrust faulted, and at two places near the Rapid River are intruded by plutonic rocks.

Unweathered limestone is dark gray (N3), and commonly weathers to light gray (N7), but at places weathers very light gray (N8), medium bluish gray (5B 5/1), light bluish gray (5B 7/1), pinkish gray (5YR 8/1), light brown (5YR 6/4), moderate orange pink (10R 7/4), and mottled grays. The limestones are rather uniformly fine to very fine grained and schistose, and are recrystallized as a consequence of intense shearing. Because the rocks lack the typical saccharoidal texture of marble, the term "metalimestone" may be a more accurate lithologic designation.

The limestones are sheared and have a high carbonate content. Shear layers are commonly about 0.1 in. (2 to $3 \mathrm{~mm}$ ) thick, but range in thickness from 0.1 to 0.4 in. ( 2 to $10 \mathrm{~mm}$ ); at only a few places is shearing not apparent. Original bedding has been almost entirely obliterated except at a few places where the distribution of shell fragments indicate the bedding to be parallel or subparallel to shear layering. The limestones are locally cut by veinlets of calcite, but contain little visible noncarbonate material, the only exceptions being a few quartz grains in rock along the Rapid River, and a few minute crystals of pyrite near intrusive rock on Cannon Ball Mountain. The limestones along the Rapid River are calcic; little magnesium was detected by a spectrographic analysis of a composite sample from this area and its northward extension outside of the study area (Hamilton, 1963b, p. 10). Minor quartz, feldspar, muscovite, magnetite, pyrite, and carbonaceous material, constituting less than 1 percent, were found in samples from the same area (Hamilton, 1963b, p. 10).

The maximum thicknesses of the limestones in the drainage of Sheep Creek are about $350 \mathrm{ft}(107 \mathrm{~m})$ for the 9-mi-long band and $175 \mathrm{ft}(53 \mathrm{~m})$ for the 2-mi-long band. These limestones are intercalated with sheared metavolcanic rocks of the Seven Devils Group, which suggests that they are in the upper part of that group. On the other hand, the lateral continuity and thickness, especially of the longer band, suggest that the limestones are thrust wedges of the Martin Bridge Limestone. Either interpretation suggests a Triassic age. It is more remotely possible that the limestones belong to other unrecognized rock units caught in the thrust faults between the Seven Devils Group ( $\mathrm{kPs}$ ) and schist and gneiss ( $\mathrm{Pzg}$ ). Fossils found in these limestones are too fragmented for identification.
The limestone on the east side of Cannon Ball Mountain occurs in two tectonic bodies, both of which are probably the Martin Bridge Limestone. The maximum exposed but incomplete thicknesses of both bodies is estimated at $1,900 \mathrm{ft}$ $(580 \mathrm{~m})$. The body to the north is somewhat less sheared near its west margin than elsewhere, and is there regarded as being either in normal contact with the underlying Seven Devils Group or only slightly displaced on top of that group. To the west, the body to the north is overthrust by the Seven Devils Group, and the original thickness is indeterminable. The body to the south is bounded by thrust faults, and its original thickness is likewise indeterminable. Neither body contains identifiable fossils, although both contain fragments of shells, and a poorly preserved brachiopod was found in the body to the north.

The band of limestone along the Rapid River ranges in thickness according to the distance between the thrust faults that confine it. The absence of a sedimentary top and bottom, and the intense internal shearing, preclude estimates of original thickness. The thickness of the limestone body is several hundred feet throughout much of its length, but is much greater, perhaps $2,000 \mathrm{ft}(610 \mathrm{~m})$, near its north end where it passes out of the study area. The limestone is probably the Martin Bridge Limestone, but the few shell fragments found in the south part of the band were too poorly preserved for identification.

\section{Martin Bridge Limestone ( $\mathrm{kmb}$ )}

The Martin Bridge Limestone (Hamilton, 1963b, p. 9-11) was previously designated the Martin Bridge Formation by Ross (1938, p. 32-36) although Ross's definition was first referred to by Gilluly and others (1933, p. 12). Limestone considered in this report to be part of the Martin Bridge Limestone is chiefly confined to a 5-mi-long $(8 \mathrm{~km})$ and nearly 2-mi-wide $(3 \mathrm{~km})$, northeast-trending band that crosses the Hells Canyon Reservoir in the southern part of the study area (pl. 1). There, the Martin Bridge Limestone is partly bounded by faults, and unconformably or possibly disconformably overlies the Seven Devils Group. The upper part of the formation is eroded, and at the southwest end of the band the limestone is capped by the Columbia River Basalt Group.

The formation consists almost entirely of dark-gray limestone (N3) that weathers to light gray (N7) and yields a fetid, petroliferous odor when freshly broken. The limestone is mostly fine to very fine grained (micrite), but locally contains small concentrations of fragments from fossils. Vallier (1977, p. 49) noted some coarser limestone (sparite and biosparite), and also dolomite, limestone breccia, and a few thin layers of shale in these rocks. The limestone is laminated at some places, but most commonly it occurs in thick beds, from 3 to $30 \mathrm{ft}$ ( 1 to $9 \mathrm{~m}$ ) thick. The beds locally contain veinlets of white, finely crystalline calcite, and pods of calcite as much as 10 in. (25 cm) in diameter. Vallier (1967, p. 123) also noted 
pods and veins of quartz. In places the lowest part of the Martin Bridge Limestone is a greenish-gray (10GY 5/2), calcareous graywacke containing fragments of volcanic rocks derived from the Seven Devils Group. The graywacke is as much as $15 \mathrm{ft}$ (5 m) thick.

Carbonate rocks from the Martin Bridge Limestone in its principal area of outcrop are calcitic, but differ considerably in content of dolomite. Twenty samples analyzed by atomic absorption yielded a range in $\mathrm{CaO}$ from 41.9 to 54.7 percent, averaging 49.8 percent, and a range in $\mathrm{MgO}$ from 0.26 to 18.3 percent, averaging 2.2 percent. Other samples from the same area contained 3-22 percent insoluble residues, and averaged 6.7 percent (Vallier, 1967, p. 123); the residues consisted of quartz, illite, chlorite, and carbonaceous material.

The base of the Martin Bridge Limestone is exposed at several places, but the upper part is eroded; thus no estimate can be made regarding the original thickness. An estimate of $1,340 \mathrm{ft}$ (405 $\mathrm{m}$ ) of exposed thickness was made on the basis of elevation differences on fold axes; this figure is slightly less than the maximum thickness of $1,750 \mathrm{ft}(534 \mathrm{~m})$ measured by Vallier (1967, p. 122) in the same area.

The Martin Bridge Limestone is considered Late Triassic (earliest Norian) on the basis of ammonites and other fossils found by Vallier (1977, p. 49-50). A few brachiopods were found during the present study, but they were too poorly preserved for identification.

\section{Coon Hollow Formation (Jch)}

The type area of the Coon Hollow Formation is along the Snake River near the intersection of the State lines of Idaho, Oregon, and Washington. The formation was named by Morrison (1964) for Coon Hollow, which is in the study area in Oregon, but the type section is across the river on a ridge on the south side of Little Cougar Creek, outside of the study area in Idaho (pl. 2). About $7 \mathrm{mi}^{2}\left(18 \mathrm{~km}^{2}\right)$ of the rock unit are in the northern part of the study area (pl. 2), and the formation also crops out in an area of a little less than $1 \mathrm{mi}^{2}\left(2.6 \mathrm{~km}^{2}\right)$ near Pittsburg Bar (pl. 2). In the north, the formation unconformably overlies the Seven Devils Group and is overlain by the Columbia River Basalt Group. Near Pittsburg Bar, the Coon Hollow Formation occurs in a wedge between thrust faults that converge to the east; to the west this outcrop is overlain by the Columbia River Basalt Group.

The Coon Hollow Formation is composed chiefly of argillite with lesser amounts of siltstone, graywacke, a few beds of conglomerate, and, near Pittsburg Bar, a few pods of limestone. The argillite is grayish black (N2), and weathers olive gray (5Y 4/1), dark greenish gray (5GY 4/1), and brownish gray (5YR 4/1). The argillite is slightly siliceous and brittle, breaking into plates with a hackly fracture; it contains carbonaceous streaks and small cubes of pyrite at many places, and is commonly laminated in layers from 0.1 to 1 in. (3 to $2.5 \mathrm{~mm}$ ) thick. Many layers contain concentrations of silt- and sand-sized particles, and the argillite grades into siltstone and graywacke. The lighter colors of the arenaceous rocks, light brownish gray (5YR 6/1) - weathering light gray (N7) and light greenish gray (5GY 8/1) —emphasize the layering. Beds of graywacke are as much as $10 \mathrm{ft}(3 \mathrm{~m})$ thick, and contain subrounded to rounded clasts of quartz, feldspar, and grains of volcanic rocks in a slightly calcareous matrix.

Conglomerates are rare in the Coon Hollow Formation, and are generally only a few feet thick, although Morrison (1963, p. 63) reported thicknesses of $20 \mathrm{ft}(6 \mathrm{~m})$. They contain well-rounded pebbles of argillite, chert, and felsite. A lithologically different conglomerate, 0-20 ft (0-6 m) thick, locally occurs at the base of the formation in its type area; this conglomerate contains pebbles, cobbles, and small boulders of volcanic rocks derived from the Seven Devils Group, and limestone, presumably derived from either the Seven Devils Group or the Martin Bridge Limestone.

The Coon Hollow Formation is intruded by numerous sills and a few dikes of andesite, andesite porphyry, diorite, and quartz diorite, and is locally cut by veinlets of calcite. The sills, which are as much as $30 \mathrm{ft}(9 \mathrm{~m})$ thick, are believed to be related to an intrusive body of diorite just north of the study area in Washington and Idaho.

The original thickness of the Coon Hollow Formation is unknown because the top of the formation is everywhere eroded, but at least 2,200 ft (690 m) and perhaps much more of the formation are exposed in the type area and the study area. A maximum thickness of $400 \mathrm{ft}(120 \mathrm{~m})$ is estimated for the section near Pittsburg Bar.

The age of the Coon Hollow Formation is not well known; fossils are rare, and none were found during the present study. Morrison (1963, p. 58-59) reported an ammonite fauna about $300 \mathrm{ft}(90 \mathrm{~m})$ above the base of the formation in its type area, indicating a Late Jurassic (early Oxfordian) age, and Vallier (1977, p. 51) reported an ammonite fauna near Pittsburg Bar indicating a Middle Jurassic (Callovian) age.

\section{Intrusive Rocks}

Stocks and plugs of granodiorite, quartz diorite, diorite, and gabbro, ranging in size from $300 \mathrm{ft}(90 \mathrm{~m})$ in diameter to bodies covering $20 \mathrm{mi}^{2}\left(52 \mathrm{~km}^{2}\right)$, intrude the Seven Devils Group and other pre-Miocene rock units. Dikes and sills are numerous; many are clearly related to plutons, but others show no such relation. Although not numerous, feeder dikes to flows in the Columbia River Basalt Group are widespread and conspicuous. Several of the plutons have been subjects of detailed studies; these include the diorite-gabbro stock near the mouth of the Imnaha River (Morrison, 1963), and the stocks in the southern part of the Seven Devils Mountains (White, 1968). More general works concerned with plutonic rocks in the study area are those of Hamilton (1963b) and Vallier (1974).

Many plutons seem randomly located, as neither their shapes nor their orientations suggest structural control. However, in the southern part of the Seven Devils Mountains (pl. 1), 
the tabular shapes and northeast elongation of the older plutons suggest that they were emplaced along parallel fractures. The shear zone extending from Temperance Creek to Pittsburg Saddle and the zone east of the mouth of the Imnaha River influenced the emplacement of plutons, but many of the relations are obscured by the overlying Columbia River Basalt Group.

The plutons have been classed as being of Late TriassicMiddle Jurassic age and Late Jurassic-Early(?) Cretaceous age or Cretaceous(?) age (White, 1968; Vallier, 1974). The distinction is a general one and is based on whether the plutons pre-date or postdate Jurassic metamorphism that affected the area. Of critical importance are the presence or absence of metamorphic alteration minerals and the presence or absence of hornfels aureoles overprinted on intruded rocks adjacent to the plutons. Further judgment of age is based on similarities to plutons of known or surmised ages in surrounding regions (White, 1968, p. 164-167).

\section{Diorite of Triassic-Jurassic Age (Jkd)}

Rocks in this unit crop out in two small plugs on the ridge north of Doyle Creek (pl. 1); in a cluster of elongated tabular stocks and plugs near White Mountain, Emerald Lake, Monument Peak, Crystal Lake, Pactolian Gulch, and Black Lake (pl. 1), and Ruth Lake and Jackley Mountain (pl. 1); in a small plug on Bull Creek (pl. 1); in a plug at Stormy Point (pls. 1 and 2); in a plug on the nose of Camel Ridge (pl. 2); in three thick sills and a connecting dike in Jones Creek (pl. 2); and in a plug in the bottom of the canyon of the Snake River near the mouths of Copper and Getta Creeks (pl. 2). In the area of most extensive distribution, such as near White Mountain and Emerald Lake, the diorite grades into gabbro and quartz diorite, but elsewhere the unit is exclusively diorite.

The diorite is medium to fine grained and equigranular. A typical sample contains plagioclase (60 percent), hornblende (20 percent), and small amounts of quartz, biotite, chlorite, epidote, and opaque minerals. At several places, most notably near Black Lake, the diorite grades into gabbro containing plagioclase (55 percent), hornblende (30 percent), and small amounts of quartz, biotite, chlorite, epidote, and opaque minerals. In the northern part of its major area of distribution, the diorite grades into quartz diorite, and near Ruth Lake, Crystal Lake, and Jackley Mountain, the unit contains more quartz diorite than diorite. A typical quartz diorite contains plagioclase (50 percent), quartz (25 percent), biotite (10 percent), and small amounts of hornblende, potassium feldspar, chlorite, and opaque minerals.

The diorite and associated gabbro and quartz diorite intrude volcanic rocks of the Seven Devils Group, and are intruded by the quartz diorite (KJgd) of the White MonumentPepperbox Hill stock in Deep Creek (pl. 1). The relation to the sheared rocks (unit my) near White Mountain and Satan Lake (pl. 1) is uncertain; they are overlain by the Columbia River Basalt Group at Jones Creek (pl. 2) and in the bottom of the canyon of the Snake River near Copper and Getta Creeks (pl. 2). The contacts with the Seven Devils Group are sharp, and with the exception of the sills on Jones Creek, steep. A few inclusions of the Seven Devils Group occur in the plutonic rocks, and a few protrusions of the plutonic rocks extend into the Seven Devils Group, but in general the boundaries between the two units are well defined. Epidote veins and veinlets are common along and near the contacts, and silicification and alteration of the volcanic rocks adjacent to the contact is nearly everywhere limited to a thickness of less than $3 \mathrm{ft}(1 \mathrm{~m})$ and commonly less than $1 \mathrm{ft}(0.3 \mathrm{~m})$.

The age relation to the sheared rocks (unit my) is uncertain. Protuberances of plutonic rocks extend into the shear zone, and the outcrop pattern of the plutonic rocks crosses the foliation of the shear zone, indicating that intrusion took place after shearing. Nevertheless, some plutonic rock was shattered and brecciated adjacent to the contact, indicating that some shearing occurred after the plutonic rocks were emplaced. Possibly, the intrusions occurred toward the end of the period of shearing.

The south end of the stock at Black Lake is truncated by quartz diorite (KJgd). The contact is not exposed, but metamorphism accompanying the intrusion of the quartz diorite produced actinolite and biotite in the older diorite. A difference in age is also suggested by a difference in regional metamorphism indicated by the cloudy saussuritized plagioclase in the diorite as opposed to the nearly fresh plagioclase in the quartz diorite.

\section{Diorite and Gabbro of Triassic-Jurassic Age (Jkdg)}

Diorite and gabbro occur in a stock at and near the confluence of the canyons of the Snake and Imnaha Rivers (pl. 2), in three plugs within $1 \mathrm{mi}(0.6 \mathrm{~km})$ northwest of the stock (pl. 2), and in several erosional windows through the Columbia River Basalt Group in the bottoms of the canyons of the Imnaha River and Cow Creek (pl. 2); all appear to be parts of one pluton. The three outlying plugs and the large part of the stock are diorite, but in the most deeply exposed part of the stock, near the bottoms of the canyons, the rock is gabbro. From there the unit grades outward and upward into diorite; in the upstream part of the Imnaha River the diorite grades into quartz diorite, which is also present in the windows along the Imnaha River and Cow Creek.

The gabbro is coarse to medium grained and equigranular, and contains plagioclase (65 percent), pyroxene, mostly augite (30 percent), and minor amounts of hornblende, quartz magnetite, and other accessory minerals. With a reduction in plagioclase and augite and an increase in hornblende, the gabbro grades into a diorite containing plagioclase (55 percent), hornblende (40 percent), and minor amounts of magnetite, chlorite, pyroxenes, and other minerals. With a reduction in plagioclase and hornblende and an increase in quartz, the diorite grades into quartz diorite containing plagioclase (45 percent), quartz (35 percent), hornblende (15 percent), and accessory biotite, chlorite, and epidote. 
Diorite and gabbro intrude the Seven Devils Group and sheared rocks (unit my), which in turn are overlain by the Columbia River Basalt Group. Contacts with the Seven Devils Group are steep and sharp around the outlying plugs, and contact effects resemble those along contacts of diorite $(\mathrm{J} k \mathrm{~d})$ and granodiorite and quartz diorite (J kgd) with the Seven Devils Group, being limited to a concentration of epidote veinlets and a slightly greater abundance of chlorite in the volcanic rocks near contacts. On the northwest side of the main stock, however, many protuberances and dikes from the stock extend into the Seven Devils Group and many inclusions of the Seven Devils Group occur in the plutonic rocks; as a result, contacts between the units are difficult to delineate. In the quartz-rich part of the stock, to the south, are many hornblende-rich xenoliths that may be incompletely digested inclusions of Seven Devils Group. That group crops out farther south along the Imnaha River in an erosional window through the overlying basalt, and a probable contact between the plutonic rock and Seven Devils Group is covered by the basalt.

The stock of diorite and gabbro intrudes and truncates a zone of sheared rocks in the bottom of the canyon of the Snake River about $2 \mathrm{mi}(3 \mathrm{~km})$ east of the mouth of the Imnaha River (pl. 2). Diorite and gabbro dikes, which are presumably related to the pluton, occur in the shear zone and range from unfoliated to intensely sheared. Diorite and gabbro in the stock are not sheared parallel to the shear zone, but do have a parallel, primary foliation. The pluton is, however, broken by numerous faults and shears that are discordant to and probably younger than the shear zone. Foliation in the stock is well developed in its quartz-rich part, which is $3 \mathrm{mi}(5 \mathrm{~km})$ south of the shear zone and its trend, but there seems to be no reason to associate the foliation of the two units.

\section{Granodiorite and Quartz Diorite of Triassic- Jurassic Age (JKgd)}

Granodiorite and quartz diorite occur in a plug on the west side of the Rapid River (pl. 1); in a stock on Little Granite Creek and the headwaters of Devils Farm Creek (pl. 1); in a stock extending from Waterspout Creek (pl. 1) across the canyon of the Snake River to Sheep Creek (pl. 1), and northward to Cold Springs Cow Camp (pl. 2); in several stocks and plugs along and in the shear zone extending across the canyon of the Snake River from Temperance Creek to near Pittsburg Saddle (pl. 2); in a stock in the canyons of the Snake River and Deep Creek (pl. 2); and in a plug in the bottom of the canyon of the Snake River near Wolf, Roland, and Thorn Creeks (pl. 2).

The granodiorite and quartz diorite are medium grained and equigranular, and although they grade into each other, their compositions differ considerably from place to place. Plagioclase is everywhere the most abundant mineral (33-67 percent), and quartz is almost everywhere the next most common (20-33 percent); the content of potassium feldspar is variable (0-20 percent). The mafic minerals (1-25 percent) are chiefly hornblende and biotite, and either or both may be present; where both are present, hornblende is generally more abundant than biotite, but where the overall content of mafic minerals is high, biotite is much more abundant than hornblende. Opaque minerals (1-3 percent) are present in all samples.

The granodiorite and quartz diorite intrude the Seven Devils Group at many places, limestone ( $\mathrm{k} P \mathrm{Pl}$ ) on the west side of the Rapid River, and sheared rocks (myd) at numerous localities in the shear zone extending from Temperance Creek to Pittsburg Saddle. The rocks are overlain by the Columbia River Basalt Group. The stock on Deep Creek and the plug in the bottom of the canyon of the Snake River near Wolf Creek crop out in erosional windows through the basalt and are not known to be in contact with other rock units.

Contacts with the Seven Devils Group are for the most part sharp and steep. Inclusions of volcanic rocks occur in the plutonic rocks, and protrusions of the plutonic rocks, dikes of granodiorite and quartz diorite, and dikes of granite, aplite, and dacite that may be related to the plutonic rocks extend into the Seven Devils Group. Contact metamorphic effects are minimal, being limited to local silicification and a slight increase in the abundance of chlorite and veinlets of epidote near the contact. Hydrothermally altered rocks of the Seven Devils Group are present both near to and at some distance from the intrusive bodies, but with the exception of one small area on the ridge between Rough Creek and Hat Creek (pl. 1), where both plutonic and volcanic rocks are altered along and near their mutual contact, the alteration seems unrelated to the intrusions.

On the west side of the Rapid River, the contact of limestone ( $\mathrm{RPIs}$ ) with quartz diorite is not exposed, but the rocks crop out within a few feet of each other, and neither appears to be altered.

The relation of the granodiorite and the quartz diorite to the sheared rocks (myd) is more complicated than the pattern on the map indicates (pl. 2). The sheared rocks are not only intruded by stocks and plugs of granodiorite and quartz diorite, but are also laced with a network of anastomosing dikes of the same rocks, and by other dikes, mostly diorite and gabbro, which may or may not be related to the plutons. The stocks and plugs cross the foliation of the shear zone, but are somewhat elongated with the strike of the foliation, and the dikes have a strong preferential orientation with the foliation, indicating structural control of the intrusions. Nevertheless, many of the dikes are themselves foliated, and some of the plutons are weakly to moderately foliated parallel with foliation in the shear zone, and slickensides on chlorite- and epidote-coated contacts indicate some post-intrusive, horizontal offset. Contact metamorphism in the shear zone is negligible, being restricted to the formation of quartz-epidote veins near plutons. Chlorite is abundant throughout the shear zone, but is not concentrated near plutonic rocks, and may have been present prior to the intrusions. No hydrothermal alteration can be definitely associated with the intrusions. Of the three small altered areas mapped along contacts of plutonic and sheared rocks, all in the drainage of Temperance Creek, two are on the 
major fault that limits the northwest side of the shear zone, and the other is on the north side of a small plug of quartz diorite in the shear zone; the alteration may have resulted from hydrothermal solutions that permeated the fractures at a later date and have no relation to the exposed plutonic rocks.

\section{Granodiorite and Quartz Diorite of Jurassic- Cretaceous Age (KJgd)}

Granodiorite and quartz diorite crop out in a stock at White Monument and Pepperbox Hill, and similar quartz diorite is present in two plugs, north and northeast of Lynes Saddle and in a stock at Echols Mountain (pl. 1). From the proximity and similarity of rocks in these plutons, it seems likely that they are parts of one body at depth.

The granodiorite and quartz diorite are medium grained and equigranular. The quartz diorite is composed of plagioclase, 55-60 percent; quartz, 15-25 percent; hornblende, 5-15 percent; biotite, 5-10 percent; potassium feldspar, 1-5 percent; and minor amounts of chlorite, epidote, and opaque minerals. The granodiorite contains plagioclase, 45-60 percent; quartz, 10-30 percent; potassium feldspar, 10-15 percent; hornblende, 1-15 percent; biotite, $0-5$ percent; and minor amounts of chlorite, epidote, and opaque minerals. The granodiorite is younger than the quartz diorite because dikes of the former cut the latter, but both are considered phases of one plutonic event.

The stock at White Monument and Pepperbox Hill contains many hornblende- and biotite-rich xenoliths, and inclusions of hornfels, volcanic rocks of the Seven Devils Group, skarn, and limestone. Sparse, small hornblende-rich xenoliths are disseminated in the central part of the stock and become more numerous and larger, up to boulder-size, toward the margin of the stock; they are believed to be metamorphosed fragments of volcanic rocks from the Seven Devils Group. Biotite-rich xenoliths are limited in distribution to the margins of the stock and are considered to have the same origin. Inclusions of volcanic rocks are restricted chiefly to the outer part of the stock, and all are partly converted to hornfels; some hornfels have no relic textures or minerals by which their parent rock can be identified. Inclusions of garnet-epidote skarn are undoubtedly remnants of limestone inclusions; large limestone inclusions are rimmed and to different extents replaced by garnet, epidote, and other minerals; the larger limestone inclusions were mapped as a separate unit (₹Plt), and are discussed under another heading.

The granodiorite and quartz diorite plutons intrude the Seven Devils Group, and the larger stock, as described previously, truncates diorite ( $\mathrm{J} \mathrm{kd}$ ). Contacts with the Seven Devils Group dip steeply and at many places are sharp; at other places the granitic rocks pervasively intrude rocks of the Seven Devils Group across zones that are as much as $1,000 \mathrm{ft}(305 \mathrm{~m})$ wide. A metamorphic aureole containing biotite surrounds the plutons, extending outward as much as $0.5 \mathrm{mi}(0.8 \mathrm{~km})$ or more.
Actinolite is present in the volcanic rocks within $3 \mathrm{ft}$ (1 $\mathrm{m}$ ) of the contact at some places, and hornfels and silicified rocks occur sporadically along the contact.

\section{Diorite of Cretaceous Age (Kd)}

Diorite crops out in small plugs in the drainage of Cook Creek (pl. 2); similar rock occurs in unmapped sills in the Coon Hollow Formation in the northern part of the study area (pl. 2), and in nearby plutonic bodies outside of the study area in the drainages of Cottonwood Creek, Big Cougar Creek, Little Cougar Creek, Cave Gulch, China Garden Creek, and Corral Creek, Idaho, and Bear Creek, Wash. (pl. 2).

The diorite at Cook Creek is medium grained, equigranular, and composed of plagioclase (55 percent), hornblende (40 percent), and minor amounts of quartz, epidote, and magnetite. The diorite is unfoliated and unmetamorphosed. The plugs intrude the Seven Devils Group, and contacts are steep, sharp, and chilled. Wall rocks are contact metamorphosed, locally converted to hornfels, and at places contain an abundance of fine-grained hornblende.

The sills in the Coon Hollow Formation contain more quartz than the plugs at Cook Creek, and many of them are quartz diorite rather than diorite; the sills also contain biotite and chlorite and more epidote than the Cook Creek rocks.

\section{Tertiary Fluvial Deposits}

Tertiary fluvial deposits (unmapped) occur sparsely throughout the study area on the unconformity that separates the pre-Tertiary rocks from the overlying Columbia River Basalt Group. These deposits are unconsolidated to very weakly consolidated and disaggregate readily, so they crop out at only a few places and generally are covered by colluvium from the overlying basalt. The presence of the deposits can nonetheless be recognized by the well-rounded pebbles, cobbles, and, at a few places, boulders of light-colored quartzite that weather out of the gravels and contrast with the other colluvial material on the slopes below the unconformity.

Tertiary fluvial deposits containing pebbles of quartzite were found at eight localities: (1) on the ridge between Hillman and Squirrel Creeks near the southeast corner of the study area (pl. 1); (2) on ridges on both sides of McGraw Creek near the south extremity of the study area in Oregon (pl. 1); (3) on Dry Diggins Ridge near the north end of the Seven Devils Mountains (pl. 1); (4) on the ridge on the north side of Quartz Creek, about $1 \mathrm{mi}(1.6 \mathrm{~km}$ ) west of the Snake River (pl. 2); (5) on both sides of Temperance Creek (pl. 2); (6) on the ridge between Kirby and Kirkwood Creeks (pl. 2); (7) at the head of Corral Creek (pl. 2); and (8) along the south side of Wild Horse Ridge in the headwaters of Kurry and West Creeks (pl. 2).

The fluvial deposits differ from place to place. The deposit between Kirby and Kirkwood Creeks is composed 
almost entirely of unindurated, limonite-stained, wellrounded white quartz and quartzite clasts ranging in size from small boulders to pebbles; other clasts include limestone and amphibolite. The gravel in part of the deposit is well sorted with boulders at the base, grading through cobbles to pebbles at the top. The deposit is about $65 \mathrm{ft}(20 \mathrm{~m})$ thick.

The gravels near Temperance Creek and north of Gold Creek are weakly indurated and poorly sorted silt- to pebblesize clasts composed mostly of angular detritus from underlying greenstone and granitic rocks, but they contain some well-rounded pebbles of quartz, quartzite, and amphibolite as much as 7 in. $(18 \mathrm{~cm})$ long. The maximum thickness of these deposits is about $33 \mathrm{ft}(10 \mathrm{~m})$ near Temperance Creek and $15 \mathrm{ft}(5 \mathrm{~m})$ north of Quartz Creek.

The string of deposits on the south side of Wild Horse Ridge may be connected, but most are not exposed. They are recognized by the quantities of white sand concentrated just below the base of the Columbia River Basalt Group and becoming unnoticeable as it becomes more and more diluted by other colluvium downslope. Where exposed, the gravels are very weakly indurated, poorly sorted, and poorly bedded, but they are concordant with the overlying basalt. In addition to the extrinsic sand and the quartz and quartzite pebbles, these deposits contain numerous small clasts derived from the underlying Kurry Creek Member of the Doyle Formation. The greatest thickness of these deposits is about $33 \mathrm{ft}(10 \mathrm{~m})$.

The occurrence at Dry Diggins Ridge is unique in that the deposits are on a ridge from which the basalt cover was eroded, but from which the gravel is incompletely stripped. The thickness and distribution of the deposit are difficult to determine because it is poorly exposed, and merges with colluvial weathering products of adjacent rocks, and because it is partly reworked by Holocene streamlets. The deposit contains silt- to boulder-sized clasts of quartzite, quartz, amphibolite, and granitic rocks mixed with volcanic rocks derived from the underlying Seven Devils Group. This deposit is auriferous, and several flakes of gold were recovered by panning during the present study.

\section{Columbia River Basalt Group (Tcb)}

The Columbia River Basalt Group covers about 60 percent of the study area and is particularly extensive on the Oregon side of the Snake River. The group consists of two principal formations in the study area, but because the rocks lack economic interest, no attempt was made to separate them in the field, and the group was mapped as an undivided unit (pls. 1 and 2).

The local relief on the pre-basalt surface, which is indicative of the original relief, is commonly 200-400 ft (60$120 \mathrm{~m}$ ), but at places, particularly near Deep Creek (pl. 2), it is as much as 2,000 $\mathrm{ft}(610 \mathrm{~m})$. The base of the basalt ranges in elevation from less than 1,000 ft (305 m) near Lower Dug Bar Rapids (pl. 1), where it is below the level of the Snake River, to $7,900 \mathrm{ft}(2,410 \mathrm{~m})$ at Horse Heaven in the Seven Devils
Mountains (pl. 1), and 8,000 ft (2,440 m) at Pollock Mountain (pl. 1). Thus, the present relief of the unconformity is more than 7,000 $\mathrm{ft}(2,130 \mathrm{~m})$, although it is difficult to determine how much of this results from original topography and how much from post-basalt orogenic movements. As Vallier (1977, p. 53) has noted, the earlier flows accumulated in the lower areas, leaving steptoes of older rocks. The later flows covered the entire area with the possible exception of the high parts of the Seven Devils Mountains.

The Columbia River Basalt Group is composed almost entirely of basalt flows and a few flow breccias. Flows commonly range from 33 to $82 \mathrm{ft}$ ( 10 to $25 \mathrm{~m}$ ) in thickness. Columnar jointing is common and is particularly well developed in the younger flows. Most flows are vesicular in their upper parts, having vesicles from minute sizes to more than 1 in. $(2.5 \mathrm{~cm})$ in diameter. Flow banding is rare. In the few flow breccias, fragments occur as rounded bodies as much as $1 \mathrm{ft}(30 \mathrm{~cm})$ in diameter.

Most basalt is dark gray (N3), but the weathered outer part of the rock, which may be a thin coating or as much as $1 \mathrm{ft}(30 \mathrm{~cm})$ thick, is moderate brown (5YR 3/4) or some similar hue and value; red hues are present at places, especially in scoriaceous rock along flow contacts. The older flows are commonly porphyritic, containing tabular phenocrysts of glassy, amber-colored andesine from 0.15 to $1.0 \mathrm{in}$. (4 to $25 \mathrm{~mm}$ ) long. Secondary minerals locally form amygdular fillings; these include a green clay mineral that is silicified at many places, chalcedony, agate, and a white zeolite. The younger flows are similar in composition to the older flows, but are uniformly very fine to fine grained, and the only minerals usually seen in hand specimens are sparse needle-like laths of plagioclase and specks of magnetite. Pyroxene is abundant, but is seldom large enough that it can be identified with a hand lens. Olivine occurs sporadically, but is likewise seldom visible. Magnetite is usually sufficiently abundant that it attracts a pencil magnet.

The thickness of the Columbia River Basalt Group differs considerably from place to place. The thickest exposed section is near the north end of the Summit Ridge (pl. 2) where the group is about 4,000 $\mathrm{ft}(1,200 \mathrm{~m})$ thick, but the group may be thicker to the west where its base is not exposed.

The group is regarded as Miocene in age on the basis of radiometric dates and fossil flora in adjacent areas (Baski and Watkin, 1973; Hamilton, 1963a, p. 13-15).

\section{Surficial Deposits}

Surficial deposits, all presumably of Pleistocene or Holocene age, include alluvial deposits (Qal), landslide deposits (Q1s), terrace gravels (Qtg), and morainal deposits (Qm).

Alluvium is present along all streams and rivers, but only the larger deposits are shown on the geologic maps (pls. 1 and 2); some deposits were omitted where their depiction would clutter the presentation of bedrock geology. The thickest deposits are on the banks of the Snake River and in fans 
at the mouths of large side streams discharging into Hells Canyon. The large deposit shown near Pittsburg Landing (pl. 2) includes much colluvium and landslide debris that was difficult to map separately from the alluvial deposits.

The steep slopes in the canyons are conducive to slumping and landsliding wherever weathering softens the bedrock sufficiently. Large landslides were mapped at Paradise Flat (pl. 1); on the east side of Twobuck Creek, between Marks and Waterspout Creeks, and at the northeast end of Johnson Bar (pl. 1); and south of Hutton Gulch and near Pittsburg Landing (pl. 2). The landslides between Marks and Waterspout Creeks seem to have occurred because of the ease with which hydrothermally altered rocks of the Seven Devils Group were weathered. At Pittsburg Landing, the Kurry Creek Member of the Doyle Formation was weathered beneath a thrust fault, reducing support for and finally causing the collapse of structurally overlying granitic and sheared rocks.

Terrace gravels — remnants of older alluvial deposits - are scattered along the Snake River and other streams, but are particularly prominent along the Snake River at Johnson Bar (pl. 1), south of Big Bar and at Pittsburg Landing (pl. 2), and at Roland Rapids and Dug Bar (pl. 2). Some deposits form a veneer on bedrock terraces; others are either fill terraces or cut-and-fill terraces. The deposits at Johnson Bar and south of Big Bar are $80 \mathrm{ft}$ (24 m) or more in thickness.

Morainal deposits are restricted to drainages from the Seven Devils Mountains, and to Pollock Mountain, east of the Rapid River (pl. 1). The deposits were not studied with adequate detail to determine if more than one period of glaciation is represented. The largest deposit is on the east side of the higher peaks in the Seven Devils Mountains, where a number of valley glaciers coalesced to form a piedmont glacier that deposited a thick moraine more than $6 \mathrm{mi}(10 \mathrm{~km})$ long.

The moraine in the canyon of Little Granite Creek on the west side of the Seven Devils Mountains is of particular interest. The main body of the deposit, its distal remnants, and terrace gravels, which are probably glacial outwash, are on gradient that intersects Hells Canyon a little above the present level of the Snake River. This indicates that the Snake River had eroded the canyon to near its present depth prior to the glaciation.

\section{Structural Geology}

Most structural features in the Hells Canyon study area are related to or affect rocks of a Jurassic (Nevadan) orogen, the most eastern bulge of which underlies most of the study area, or are related to or affect rocks of a Cretaceous orogen, the western edge of which underlies the southeast fringe of the study area (pl. 1). Rocks of the Cretaceous orogen are displaced westward over rocks of the Jurassic orogen by a belt of thrust faults. Structural features in the Jurassic orogen consist of folds, faults, foliation, and zones of sheared and mylonitized rocks with associated, aligned plutons. Most of these structures trend northeast; a few trend northwest.
In contrast, the Cretaceous orogen contains north-trending thrust faults and strongly foliated rocks that trend principally north but also northeast and east. Over both orogens is the sequence of gently warped and faulted basalt flows that form the Columbia Plateau. Despite their differences, the distinction between the structural features of the two orogens is not everywhere obvious; Cretaceous fabrics or structures related to the Cretaceous orogen are impressed upon rocks of the Jurassic orogen (Hamilton, 1963b, p. 16); and folds and faults, apparently characteristic of the Jurassic orogen but postdate Jurassic metamorphism, may instead be related to structural developments associated with Cretaceous plutons. Similarly, the youngest structures - faults formed during the post-Miocene-are impressed on both the Jurassic and Cretaceous orogens. The post-Miocene faults are mostly north-trending, high angle, normal faults, but some post-Miocene faulting may have occurred along pre-existing structures related to the Jurassic orogen (Nolf, 1966, p. 124-125).

The geologic structures mapped during the course of this work are mostly those that are clearly evident or are inferred from convincing evidence. Many of the faults shown on the geologic maps of Morrison (1963) and Vallier (1974) were not seen, although they cover substantial parts of the study area; however, they may exist even though they were not mapped. Certainly, the structural geology in the Hells Canyon study area is much more complex than is depicted on our maps.

\section{Jurassic Orogen}

\section{Shear Zones}

Major vertical shear zones containing mylonite, protomylonite, and foliated rocks with associated dikes and plutonic bodies are located (1) near White Mountain and Satan Lake (pl. 1), (2) from Temperance Creek to Klopton and Kurry Creeks (pl. 2), and (3) between Dug Bar and the mouth of the Imnaha River (pl. 2).

The zone near White Mountain and Satan Lake consists of two en echelon bodies with a narrow connecting neck. The shear zone occurs within rocks of the Seven Devils Group, and that group and the shear zone are intruded by diorite and quartz diorite (JKd). Much of the rock in the shear zone can be recognized as volcanic rock of the Seven Devils Group, but the mylonite, protomylonite, and amphibole schist could have been derived from older rocks. Although shattering of plutonic rocks adjacent to the shear zone suggests that some shearing took place after the plutonic rocks were emplaced, the intrusive relations indicate that the major tectonic activity along the shear zone occurred prior to the intrusions. Indeed, the tabular shapes and parallelism of the plutonic bodies of diorite $(\mathrm{J} \mathrm{kd}$ ) in this vicinity and northward to Crystal Lake and Jackley Mountain (pl. 1) suggest similarity in structural control by a set of fractures parallel to the shear zone. The same pattern also exists to the south, outside of the study area, in the Oxbow-Cuprum shear zone of Vallier (1974, p. 12).

The shear zone extending from Temperance Creek across the canyon of the Snake River to Klopton and Kurry Creeks 
originally may have been in rocks of the Seven Devils Group, which now borders the zone on its southeast side. The northwest side is bounded by faults and by granitic rocks that were intruded into the shear zone and the Seven Devils Group. As previously mentioned, the sheared rocks were intruded by dikes of diorite and gabbro, and later by dikes and plutons of granodiorite and quartz diorite. The basic intrusives are more strongly foliated than the acidic intrusives; all of these intrusives are aligned in the shear zone with the foliation. Several periods of tectonic activity seem necessary to explain these features, and the following is a possible sequence of events. During or after an early period of shearing, the zone was intruded by dikes of diorite and gabbro. Then, during or following a second period of shearing, the zone was intruded by dikes and plutons of granodiorite and quartz diorite. A third period of less intensive shearing may have caused the horizontal slickensides that are present on the contacts of the later granitic rocks. The shear zone presumably controlled the location of the dikes and must have existed first. At least two periods of shearing are necessary to explain the difference in the intensity of shearing in the intrusive rocks.

The shear zone between Dug Bar and the mouth of the Imnaha River contains amphibole schist, chlorite-quartz schist, and protomylonite resembling similar rocks in other shear zones. Some of the chlorite-quartz schist resembles schist derived from the Seven Devils Group, but as previously mentioned, lacks the distorted breccia fragments that elsewhere help identify the volcanic rocks. The zone is intruded by small plutons of diorite and gabbro and by many dikes of these rocks and of quartz diorite, and the zone is truncated at its west end by a large pluton. The dikes in the shear zone have a complete structural range from unfoliated to intensely sheared varieties, suggesting that they were emplaced during the last and perhaps only period of tectonic activity.

\section{Thrust Faults and Related Folds}

A group of thrust faults with associated folds is located near Cannon Ball Mountain (pl. 1) and near Pittsburg Landing (pl. 2). Two thrust faults, one overriding the other, are present near Cannon Ball Mountain. The trace of the lower fault is $2 \mathrm{mi}$ ( $3 \mathrm{~km}$ ) long and trends northward along Cottonwood Creek from its confluence with West Fork Rapid River and then hooks at right angles to the east, to the north side of Mount Sampson; the lower fault is overridden at both ends by the upper fault. The upper fault has an irregular trace, $7 \mathrm{mi}$ (11 km) long; it trends eastward along the lower part of Bridge Creek and part of the West Fork Rapid River and then meanders northward. The lower fault displaces Permian(?) and Triassic limestone ( $\mathrm{RPIs}$ ) westward over the Seven Devils Group, but the horizontal displacement is only about 1,000 ft (305 m). The upper fault displaces the Seven Devils Group westward or northwestward over Triassic limestone and rocks of the Seven Devils Group and has a much greater but unknown amount of horizontal movement. It is possible to distinguish these thrust faults of the Jurassic orogen from the nearby thrust faults of the
Cretaceous orogen along the Rapid River because the pluton of quartz diorite ( $\mathrm{J} \mathrm{kgd}$ ) intrudes the overriding plates of the older faults, but does not intrude and is overridden by the lowest thrust fault related to the Cretaceous orogen.

A major thrust fault or high-angle reverse fault with anastomosing thrust fault splinters and associated parallel folds and minor thrust faults crosses the Snake River near Pittsburg Landing (pl. 2). The principal fault, which strikes N. $50^{\circ}$ E., was mapped for a length of $7 \mathrm{mi}(11 \mathrm{~km})$ between the covering Columbia River Basalt Group on opposite sides of the canyon. Along the fault, mylonite, foliated, and schistose rocks (myd) and granodiorite and quartz diorite (J Kgd) were thrust northwestward an unknown distance over the Seven Devils Group, the Kurry Creek Member of the Doyle Formation, and the Coon Hollow Formation; the horizontal displacement is not great because of the high angle of the fault. Along the splinter faults, the Seven Devils Group was thrust over the Kurry Creek Member and the Coon Hollow Formation, and the Coon Hollow Formation was thrust over the Kurry Creek Member. Along the minor outlying faults, the Kurry Creek Member was thrust over itself. The intensity of folding in the Kurry Creek Member diminishes northwestward from the major fault. The folds nearest to the fault are overturned to the northwest; the more distant folds are broad and open, but asymmetric in accord with the direction of compression.

\section{Northeast-Trending Folds}

In addition to the northeast-trending folds near Pittsburg Landing, a second set of northeast-trending folds occur in the Jurassic orogen at the north end of the study area (pl. 2). This set of folds includes five synclines and four intervening anticlines with moderately to gently dipping limbs. The folding is localized chiefly in the Coon Hollow Formation although rocks of the Seven Devils Group just south of their contact with the Coon Hollow Formation are affected. Farther south, the structures in the Seven Devils Group have a northwest trend and any effect of the folding to the north is obscure.

A third set of northeast-trending folds is near Hells Canyon Reservoir in the southern part of the study area (pl. 1). The folds are prominent in the Martin Bridge Limestone, and are also present but not so well developed in the more competent and massive Seven Devils Group adjacent to the limestone. The folded limestone occurs in a graben, the faults of which truncate limbs of folds in the limestone, indicating that the compression that caused the folding took place before the faulting.

\section{Northeast-Trending Faults}

Several northeast-trending faults in the southern part of the study area (pl. 1) displace the Martin Bridge Limestone and the Seven Devils Group. Two branching normal faults define a graben, and a third fault is a shear or strike-slip fault with right lateral motion. Slivers of Martin Bridge Limestone occur along several fault branches, but the base of the Martin Bridge Limestone, which would be a reliable marker for measuring the 
amount of vertical displacement, is nowhere present outside of the graben, and no accurate estimate can be made regarding the displacement. Nevertheless, the minimum separation along the margins of the graben must be at least equal to the uneroded thickness of the Martin Bridge Limestone-estimated to be $1,340 \mathrm{ft}$ (405 m). The shear fault, which at Haley Ridge passes into a shear zone $600 \mathrm{ft}$ (180 m) wide, occurs in the Seven Devils Group and may be related to the parallel shear zone near White Mountain and Satan Lake. The south end of this fault terminates the faults that merge to form the northwest side of the graben, but is itself truncated by the fault forming the southeast side of the graben. This suggests a contemporaneity of the faults despite their different types of displacement.

A normal fault $6 \mathrm{mi}(9 \mathrm{~km})$ long strikes N. $50^{\circ}$ E. along and through the northwest margin of the shear zone at Temperance Creek (pl. 2). The fault is downthrown on its northwest side, as indicated by slickensides, but despite its length, vertical displacement is believed to be small; where the fault passes from granodiorite and quartz diorite ( $\mathrm{J} \mathrm{kgd}$ ) into sheared rocks (myd), contacts on opposite sides of the fault are scarcely offset. The position and orientation of the fault were probably determined by pre-existing structures, the original contact between the granitic and sheared rocks, and the foliation of the sheared rocks.

The normal fault that crosses Hells Canyon at Saddle and Bernard Creeks strikes N. $80^{\circ}$ E., a trend unknown elsewhere in either the Jurassic or Cretaceous orogens within the study area. The fault is $8 \mathrm{mi}(13 \mathrm{~km})$ long, and it is confined to the Seven Devils Group; the amount of vertical displacement is unknown.

\section{Northwest-Trending Folds and Faults}

Northwest-trending structures in the Jurassic orogen are restricted to the northern part of the study area. Besides the shear zone already mentioned, these include several folds in the Seven Devils Group along the Imnaha River between Horse and Fence Creeks (pl. 2), folds in the Seven Devils Group in the drainage of Cook Creek (pl. 2), and faults along the Snake River from near the mouth of the Salmon River to north of Jim Creek (pl. 2).

The folds along the Imnaha River are open folds striking N. $30^{\circ} \mathrm{W}$. and have moderately dipping limbs. The folds are exposed in a narrow erosional window through the Columbia River Basalt Group, and it is impossible to trace them northward to the nearest exposures of the Seven Devils Group near the Snake River, $9 \mathrm{mi}(14 \mathrm{~km})$ away. The folds near Cook Creek strike from N. $30^{\circ}$ W. to N. $60^{\circ}$ W. and resemble the folds along the Imnaha River, and it is possible that a continuous zone of folding exists from one area to the other even though no folds were mapped in the narrow intervening drainages where pre-basalt rocks are exposed.

The northwest-trending faults along the Snake River are in the Seven Devils Group. These include a 4-mi-long $(6.4 \mathrm{~km})$ fault at the confluence of the Snake and Salmon Rivers and others of shorter length. Many small faults of minor displacement were not mapped. Several limestone beds in the Seven Devils Group were useful markers in determining the throw of the faults, and because the limestone beds were involved in northwest-trending folds, it is clear that the faulting postdated the folding. The northern limit of the northwest-trending faults is at the northern limit of the Seven Devils Group, where one fault terminates at the unconformable contact with the overlying Coon Hollow Formation; no northwest trending faults were found to the north in the Coon Hollow Formation. Because the contact and the Coon Hollow Formation are involved in a group of northeast-trending folds, the northwest-trending faults are older than those folds. Thus, the faults are considered intermediate in age between the older, northeast-trending folds in the Seven Devils Group and the younger, northeast-trending folds in the Coon Hollow Formation.

\section{Cretaceous Orogen}

Thrust faults related to the west margin of the Cretaceous orogen are prominent structural features in the southeastern part of the study area. Movement on these faults has affected rocks of both Jurassic and Cretaceous orogens, and overthrusting along all of the faults is westward.

Three north-trending thrust faults are near the Rapid River. The east fault extends from the north side of North Star Butte to north of Lockwood Point, a distance of $6 \mathrm{mi}(10 \mathrm{~km})$ (pl. 1), and occurs within the Cretaceous orogen; rocks consisting mostly of gneisses were thrust over rocks consisting mostly of schists. The middle and west faults extend from the headwaters of the Rapid River, approximately parallel to the river, for $16 \mathrm{mi}(25 \mathrm{~km})(\mathrm{pl} .1)$. The middle fault forms the boundary between schists of the Cretaceous orogen in the upper plate and Triassic limestone of the Jurassic orogen in the lower plate. The trace of the west fault is very close to that of the middle fault, but the west fault is in the Jurassic orogen where Triassic limestone is thrust over volcanic rocks of the Seven Devils Group and Triassic-Jurassic quartz diorite.

Another north-trending thrust fault within the Jurassic orogen, which is probably related to the Cretaceous orogen, extends from the headwaters of East Fork Sheep Creek (pl. 1) for $12 \mathrm{mi}(19 \mathrm{~km})$ to Buckhorn Spring (pl. 2). Along this fault, Triassic limestone and rocks of the Seven Devils Group are thrust over other rocks of the Seven Devils Group. A shear zone subparallel to the east side of the trace of the thrust fault probably also is related to the Cretaceous orogen.

The details of folding in the Cretaceous orogen were not mapped, but slight differences were noted between the lower plate of schists and the upper plate of gneisses on the east side of the Rapid River (pl. 1). Most schist is strongly foliated and isoclinally folded, at least on a small scale. The strike of the foliation is generally northward and the dip moderate to steep toward the east, orientations that are subparallel to the thrust faults.

The gneisses are locally isoclinally folded, but foliation is not everywhere well developed, and its rather general 
strike toward the north is much less persistent than that of the schists.

The Cretaceous foliation impressed on rocks in the Jurassic orogen is strong, but restricted to the vicinity of the thrust faults and shear zone. The foliation in all of these rocks strikes parallel to the north trend of the major structures and dips toward the east. As a result of the perfect cleavage of calcite, the Triassic limestones were particularly susceptible to shearing, and the strong foliation in the limestones undoubtedly resulted from considerable internal gliding within the limestone units. Foliation is quite pronounced in the Seven Devils Group too, both in the shear zone and between it and the thrust fault in the East Fork Sheep Creek-Buckhorn Spring area; however, shearing was not so intense as to obliterate the distended breccia fragments in the volcanic rocks.

\section{Post-Miocene Faults}

Two post-Miocene normal faults with significant displacement were mapped, one in the Cretaceous orogen and one in the Jurassic orogen. The fault in the Cretaceous orogen extends for only $0.5 \mathrm{mi}(0.8 \mathrm{~km})$ into the eastern part of the study area, where Hillman Creek flows into Boulder Creek (pl. 1), but has a mapped length of more than $30 \mathrm{mi}(48 \mathrm{~km})$ (Hamilton, 1969) and a throw of at least 1,000 ft (305 m) at Boulder Creek. The fault strikes north and displacement is down on the east side, bringing Columbia River Basalt Group against schist and gneiss ( $\mathrm{P}_{\mathbf{z g}}$ ) of the Cretaceous orogen to the west.

The fault in the Jurassic orogen is on the west side of the canyon of the Snake River and crosses Lonepine, Tryon, Camp, and Hog Creeks (pl. 2). This north-trending fault is $6 \mathrm{mi}(10 \mathrm{~km})$ long, and it brings the lower part of the Columbia River Basalt Group against the Seven Devils Group; its throw, at Tryon Creek, is about $300 \mathrm{ft}(100 \mathrm{~m})$, down on the west side.

A few other north-striking, post-Miocene, normal faults offset the Columbia River Basalt Group, and although not numerous, they are characteristic of the Columbia Plateau near the west margin of the Cretaceous orogen (Hamilton, 1963a, p. 16).

\section{Aeromagnetic and Gravity Surveys}

\author{
By Don R. Mabey
}

\section{Introduction}

Aeromagnetic and gravity data were obtained as part of the survey of the Hells Canyon study area. The purpose of the aeromagnetic survey was to define the magnetic field in detail adequate to interpret the magnetic anomalies in terms of the location and geometry of the major rock units. The gravity survey was less detailed and was designed to define only the regional gravity anomalies. To help interpret the geophysical data, the density and magnetic susceptibility of representative rock samples were measured.

\section{Physical Properties}

Density and magnetic susceptibility of 35 rock samples representing the major rock types of the area were measured by Gordon R. Johnson. The measurements are summarized in table 2. Rocks in the Hells Canyon study area are denser and have a higher magnetic susceptibility than the average for rocks in the upper continental crust. The average density of the 35 rocks measured was $2.82 \mathrm{~g} / \mathrm{cm}^{3}$, and the susceptibility of 23 of the rocks was greater than $4 \times 10^{-4} \mathrm{emu} / \mathrm{cm}^{3}$. The densest rocks are gabbro, Tertiary basalt flows, and some of the greenstones. These rocks, along with diorite and quartz diorite, also have the highest magnetic susceptibility. The lowest densities measured were for one of the greenstones and a silicic tuff. The low-density greenstone and a limestone had susceptibilities too low to be measured with the techniques used (less than $\left.1 \times 10^{-6} \mathrm{emu} / \mathrm{cm}^{3}\right)$.

\section{Aeromagnetic Data}

The aeromagnetic survey was made by Geometrics, Inc. using a proton precession magnetometer flown along east-west flight lines $1 \mathrm{mi}(1.6 \mathrm{~km})$ apart and 9,000 ft (2,800 m) above sea level (U.S. Geological Survey, 1980). Processing of the magnetic data and preparation of a residual total intensity map was done by digital computer. A contour map of the total magnetic intensity at the 9,000-ft flight level with the IGRE field removed is shown on figure 9. The automatic contour program used in preparing the detailed maps occasionally generates closures between flight lines that may not be supported by the data along the flight lines; hence, the location of the flight lines should be considered when examining the contours. The Hells Canyon study area is one of extreme topographic relief, and the separation between the level of the aeromagnetic survey and the land surface ranges from less than $500 \mathrm{ft}(150 \mathrm{~m})$ in the vicinity of the higher peaks in the Seven Devils Mountains to more than $8,000 \mathrm{ft}(2,400 \mathrm{~m})$ over the Snake River at the north edge of the survey. The surface rocks over much of the study area are strongly magnetized, and the magnetic field at the flight level is affected by surface relief. To minimize the effect of topography, the magnetic data, which were obtained at a constant elevation, were projected onto a surface parallel to and 8,000 ft $(2,440 \mathrm{~m})$ above the land surface by B. K. Bhattacharyya using a technique he developed (Bhattacharyya and Chan, 1977). The resulting magnetic contour map (fig. 10) is less affected by the surface topography than the contour map at the flight level, but the amplitudes of the anomalies are reduced and the short wavelength anomalies are deemphasized.

Over the study area, the magnetic field is complex, reflecting both the strongly magnetized rock and the high 
Table 2. Density and magnetic susceptibility of major rock types in the Hells Canyon study area.

\begin{tabular}{|c|c|c|c|}
\hline Rock type & $\begin{array}{l}\text { Number of } \\
\text { samples }\end{array}$ & $\begin{array}{c}\text { Density range } \\
\left(\mathbf{g} / \mathrm{cm}^{3}\right)\end{array}$ & $\begin{array}{c}\text { Susceptibility range } \\
\left(\text { emu/cm } \mathbf{c m}^{3}\right)\end{array}$ \\
\hline $\begin{array}{l}\text { Basalt flow, Columbia River } \\
\text { Basalt Group }\end{array}$ & 7 & $2.89-2.95$ & $7.0 \times 10^{-4}-2.2 \times 10^{-3}$ \\
\hline Gabbro & 6 & $2.86-2.97$ & $2.4 \times 10^{-3}-7.5 \times 10^{-3}$ \\
\hline $\begin{array}{l}\text { Greenstone, Seven Devils } \\
\text { Group }\end{array}$ & 1 & 2.65 & $1 \times 10^{-6}$ \\
\hline $\begin{array}{l}\text { Greenstone, Seven Devils } \\
\text { Group }\end{array}$ & 6 & $2.71-2.93$ & $1.7 \times 10^{-5}-3.5 \times 10^{-3}$ \\
\hline Diorite and quartz diorite & 4 & $2.73-2.87$ & $2.2 \times 10^{-3}-4.6 \times 10^{-3}$ \\
\hline Gneiss and schist & 3 & $2.71-2.87$ & $2.0 \times 10^{-5}-4.2 \times 10^{-4}$ \\
\hline $\begin{array}{l}\text { Volcanic rock, Kurry Creek } \\
\text { Member }\end{array}$ & 3 & $2.70-2.79$ & $3.4 \times 10^{-5}-7.2 \times 10^{-5}$ \\
\hline Slaty mudstone & 3 & $2.73-2.78$ & $1.8 \times 10^{-5}-3.3 \times 10^{-5}$ \\
\hline Limestone & 1 & 2.70 & $1 \times 10^{-6}$ \\
\hline Silicic tuff & 1 & 2.68 & $4.2 \times 10^{-4}$ \\
\hline
\end{tabular}

surface relief. At the level of the survey, the residual magnetic intensity ranges from +612 gammas to -424 gammas. The magnetic intensity is generally high in the area west of the Snake River that is blanketed by basalt of the Columbia River Basalt Group and lower east of the river. Magnetic highs occur over many of the plutons and lows occur over altered rocks of the Seven Devils Group in the Oxbow Creek area (pl. 1). East of the Snake River the magnetic anomalies have a northeast grain apparently related to the northeast-trending shear zones and related diorite plutons.

Some magnetic features are best illustrated on the constant terrain clearance map (fig. 10). On this map, the magnetic effect of variations in distance between the flight level and the ground surface has been largely eliminated, but if the thickness of strongly magnetic units varies because of surface relief, the resulting magnetic anomaly will resemble the anomaly on the constant-altitude map; for instance, if the basalt underlying a canyon is thinner than in adjoining areas, this canyon will also be expressed as a magnetic anomaly (low) on the constant terrain clearance map.

The high magnetic intensity shown in the western part of the study area is due to the basalt of the Columbia River Group. These rocks are strongly magnetized, thick, and at a generally high elevation. Their remnant magnetization was not measured as part of this study, but Watkins (1965) reports from his studies of the remnant magnetization of a $2,780-\mathrm{ft}$ (850-m) section of the basalts near Imnaha, Oreg., that five successive pairs of zones of normal and reverse magnetization are present and that normal and reversed flows occur in about equal numbers. Although the primary source of the magnetic high in this area is obviously the basalt, the causes of the local variations within the broad anomaly are uncertain.

Variations in the thickness of the basalt resulting from relief on its base are a likely cause of part of the magnetic relief. The basalt was extruded over an irregular surface with local relief of up to $2,000 \mathrm{ft}(610 \mathrm{~m})$. The maximum known thickness of the basalt is about 4,000 $\mathrm{ft}(1,200 \mathrm{~m})$; thus, the relief on the base could produce large variations in the thickness and consequent large variations in the magnetic anomaly produced by the basalt. Although the presence of both normal and reverse remnant magnetization in the basalt makes any quantitative interpretation of the magnetic anomalies associated with the basalt of questionable value, a correlation between magnetic intensity and thickness of the basalt appears to exist. The magnetic low near the mouth of Summit Creek (pl. 1), for example, coincides with a window in the basalt. The magnetic data also suggest that a prism of thicker basalt extends south from the basalt low in the Snake River Canyon east of the mouth of Deep Creek (pl. 1).

Not all of the magnetic anomalies over the basalt reflect the thickness of the basalt; some may reflect source areas of the basalt flows. The rocks underlying the basalt of the Columbia River Group west of the Snake River are probably magnetically similar to the pre-basalt rocks exposed to the 
east that produce large magnetic anomalies. Thus, some of the magnetic relief in the area covered by the basalt probably is produced by the older rocks, as is apparent in several places where magnetic anomalies can be traced under the basalt.

East of the area covered by the Miocene basalt flows, most of the magnetic anomalies are caused by large bodies of Mesozoic intrusive rocks. However, in several areas, anomalies produced by units of the Seven Devils Group are apparent. More detailed geologic mapping of the Seven Devils Group would likely define units with considerably higher magnetization than the average for the group.

The highest magnetic intensity outside of the area covered by the Columbia River Basalt Group is over the northeast end of the quartz diorite pluton of Sheep Creek (pl. 1). With slightly less amplitude, the anomaly extends southwest along the exposed part of the pluton. At the south end, the magnetic data indicate that the pluton underlies rocks of the Seven Devils Group in an embayment in the pluton. The anomaly is interrupted where Sheep Creek cuts into and thins the pluton. A lower amplitude high is produced by the quartz diorite outcropping in a zone trending southwest from Grave Point (pl. 2). On the northeast and southwest, this anomaly merges with larger highs produced by basalt of the Columbia River Basalt Group.

A magnetic high also occurs in the area of the quartz diorite pluton of Little Granite Creek (pl. 1). However, the two closed magnetic highs lie east and south of the exposed parts of the pluton, and the pluton itself is an area of low magnetic intensity relative to these adjacent areas; therefore, this magnetic high is not produced by the exposed rocks of the pluton. Three erosional remnants of basalt of the Columbia River Group occur to the southeast and northeast of the Granite Creek pluton, but they are not a significant cause of the anomaly. The areas of highest magnetic intensity associated with this anomaly are over rocks of the Seven Devils Group and in the Granite Mountain area (pl. 1). A correlation between magnetic intensity and topography is apparent. Elsewhere, a shallow source for the anomaly is indicated. Clearly, part of the anomaly is produced by rocks of the Seven Devils Group. On the constant terrain clearance map (fig. 10), where the effect of topography is minimal, the anomaly is a prominent feature with the highest intensity south of the outcrop of the pluton. A mass of considerable volume is required to produce the measured anomaly. The anomaly may reflect a large unit in the Seven Devils Group with substantially higher magnetism than normal for this group. The anomaly could also reflect a highly magnetized phase of the pluton along the south and east margins that is now largely covered by the Seven Devils Group. Because the source of the anomaly is not deeply buried, a more detailed examination of the surface geology might reveal the source of the anomaly.

Diorite and quartz diorite of Triassic-Jurassic age crop out in a large area extending south and southwest from Ruth Lake (pl. 1). A complex magnetic high overlies this area and extends southwest to near the southwest corner of the study area. The magnetic data suggest that this area is underlain by a continuous or nearly continuous mass of these intrusive rocks.

A magnetic high of low amplitude is associated with the zone of granodiorite and quartz diorite extending northeast from Temperance Creek (pl. 2). The modest magnetic expression of the intrusive rocks in this zone can be explained if the thrust fault that has been mapped along the northwest side of this zone flattens at depth and extends at relatively shallow depths under the zone. Alternatively, the magnetization or volume of the rock may be small.

Gabbro of Triassic-Jurassic age crops out in the Snake River Canyon near the mouth of the Imnaha River and in Cook Creek Canyon (pl. 2). In both areas, basalt of the Columbia River Group overlaps onto the gabbro from the south. A complex magnetic high with three closures occurs near the north edge of the basalt and extends over the outcropping gabbro. The magnetic data suggest that the gabbro may be part of a much larger mass of gabbro extending for several miles under the cover of basalt. A similar high between Deep Creek and the Snake River (pl. 2) is also south of outcropping gabbro in the Snake River Canyon and may also, in part, reflect a large mass of gabbro under the basalt.

A magnetic low of possible resource interest occurs over rocks of the Seven Devils Group in the area of Oxbow Creek and Deep Creek (pl. 1). The magnetic intensity here is the lowest measured in the study area. Rocks of the Seven Devils Group occupy all of the area of the magnetic low, and zones of hydrothermal alteration and silicification occur at several locations within the low. Most of the greenstones of the Seven Devils Group are strongly magnetized but alteration resulting in the destruction of the magnetic minerals could destroy the magnetization. The magnetic low in the Oxbow-Deep Creek area may reflect an extensive area where alteration has greatly reduced the magnetization of rocks of the Seven Devils Group or rocks that were originally less strongly magnetized. A zone of relatively low magnetic intensity extends northeast from this low to Heavens Gate. The entire length of this low is apparently underlain by less strongly magnetized rocks of the Seven Devils Group. The low trend also extends southwest to the border of the study area where Triassic limestone underlies the zone of low magnetic intensity.

Another zone about $12 \mathrm{mi}(19 \mathrm{~km})$ long containing hydrothermally altered rocks of the Seven Devils Group trends northeast from Johnson Bar (pl. 1). A magnetic low is also associated with this zone, indicating that the magnetization of the rocks in this zone has also been reduced. Finally, a magnetic low is centered over sedimentary rocks at Pittsburg Bar.

\section{Gravity Data}

Gravity stations were established by Dolores M. Kulik at 72 points in the study area where the elevation could be determined from topographic maps. In addition, data for 13 stations were obtained from the files of the Department of Defense. The observed gravity values were referenced to ACIC 


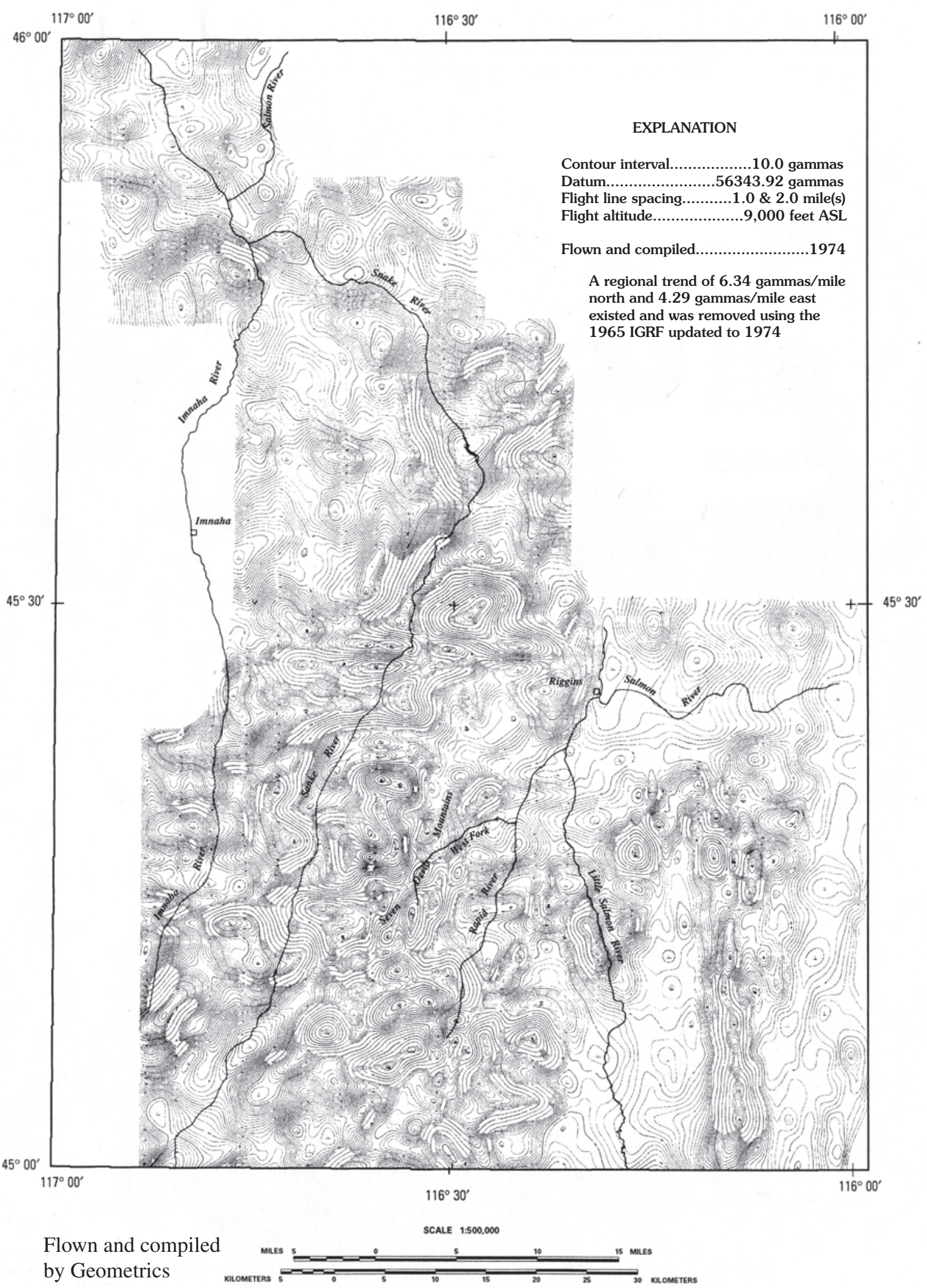

Figure 9. Residual magnetic intensity map of Hells Canyon study area and vicinity. Contour interval, 20 gammas. 


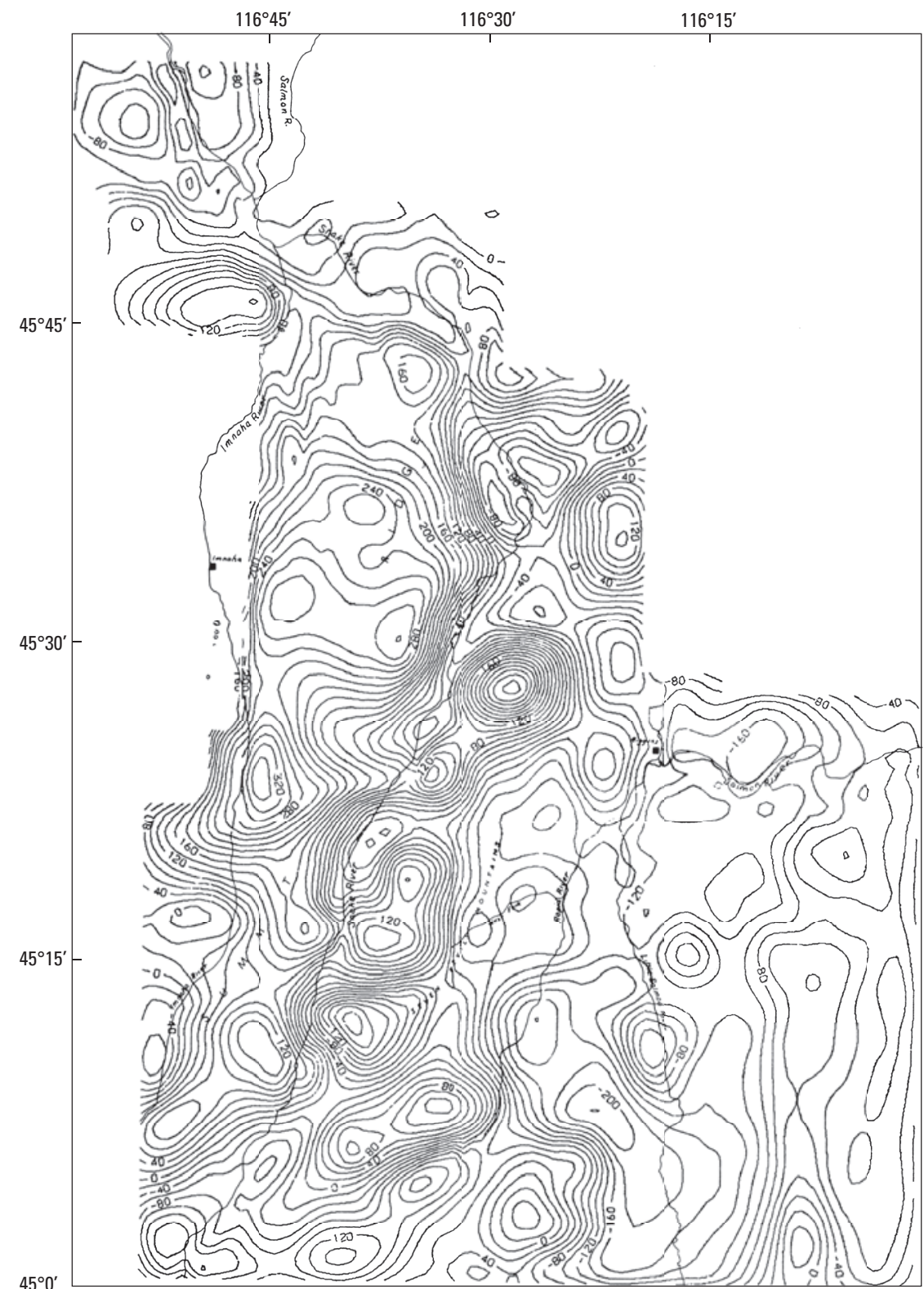

Figure 10. Constant terrain clearance residual aeromagnetic map of Hells Canyon study area and vicinity. Terrain clearance, 8,000 ft (2,440 m). Contour interval, 20 gammas. (For more a more detailed aeromagnetic map, see U.S. Geological Survey, 1980.) 
base station 4606-1 at Enterprise, Oreg. (observed gravity value $980299.59 \mathrm{mGal}$ ) and reduced to the complete Bouguer anomaly assuming densities of both 2.67 and $2.85 \mathrm{~g} / \mathrm{cm}^{3}$ for material above sea level. Corrections were applied for topography to a distance of $100 \mathrm{mi}(160 \mathrm{~km})$. The standard density used in the reduction of gravity data in most regional surveys is $2.67 \mathrm{~g} / \mathrm{cm}^{3}$; however, the average measured density of the 35 surface rocks in the Hells Canyon study area is $2.82 \mathrm{~g} / \mathrm{cm}^{3}$. Large volumes of rock in the study area have a density of more than $2.9 \mathrm{~g} / \mathrm{cm}^{3}$, so increasing the density factor in the Bouguer anomaly reduction by $0.15 \mathrm{~g} / \mathrm{cm}^{3}$ would produce a change in the Bouguer anomaly of $2 \mathrm{mGals}$ per $1,000 \mathrm{ft}$ (305 m) of elevation. With over 8,000 ft $(2,400 \mathrm{~m})$ of relief in the study area, anomalies reflecting topography might be over 7,610 mGals. The major anomaly related to topography resulting from an assumed density lower than the actual density is low Bouguer anomaly values for stations in the bottom of Hells Canyon relative to stations in the topographically high adjoining areas. Therefore, in addition to the standard Bouguer anomaly, a second Bouguer anomaly was computed assuming a density of $2.85 \mathrm{~g} / \mathrm{cm}^{3}$. Contours of both anomalies are shown on figure 11. South from Hat Point, the $2.67-\mathrm{g} / \mathrm{cm}^{3}$ Bouguer anomalies for stations in the canyon are generally lower than those outside of the canyon, but this relationship is largely gone if a density of $2.85 \mathrm{~g} / \mathrm{cm}^{3}$ is used. North from Hat Point, the relation between the Bouguer anomaly and topography is more complex. Anomalies that are defined by both sets of contours probably reflect subsurface mass anomalies, but those that are defined by only one may reflect topography.

The rocks in the Hells Canyon study area can be grouped into two density sets. The higher density set consists of gabbro, basalt, diorite, magnetic units in the Seven Devils Group, and a gneiss; the density of these rocks ranges from 2.84 to $2.98 \mathrm{~g} / \mathrm{cm}^{3}$. The lower density set includes several volcanic units and related mud flows, limestone, gneiss, schist, quartz diorite, and a nonmagnetic rock of the Seven Devils Group; the density of this set ranges from 2.65 to $2.79 \mathrm{~g} / \mathrm{cm}^{3}$. Density contrasts in this large and complex structure indicate that local Bouguer gravity anomalies of several milligals amplitude undoubtedly occur throughout the study area, but the spacing of the gravity observations is not adequate to define these local anomalies, although adequate to define broad regional features.

The Bouguer anomaly values decrease southeastward across the study area. This regional gradient reflects a regional mass anomaly related to the isostatic compensation for the higher average surface elevation toward the southeast.

Two coincident areas of high gravity closure occur on both sets of Bouguer gravity contours in areas covered by basalt of the Columbia River Group. The southern high is in the area of Morgan Ridge with the highest Bouguer anomaly value in a window of Mesozoic rocks surrounded by basalt. Clearly, the primary source of the gravity anomaly is in the pre-basalt rocks. The high gravity is approximately coextensive with the area of highest magnetic intensity on the constant terrain clearance map, which also appears to reflect a body underlying the basalt. Another gravity high is centered near the mouth of Temperance Creek. Although much of the area of this anomaly is covered by basalt of the Columbia River Group, the highest Bouguer anomaly is in the Snake River Canyon below the basalt in a zone of sheared rocks of the Seven Devils Group of Early Permian-Late Triassic age and granodiorite and quartz diorite intrusives. The highest gravity value is in an area of relatively low magnetic intensity. No correlation between either of these gravity highs and any geologic units is apparent. Both probably reflect large positive mass anomalies in the subsurface. A subtle gravity low at Granite Creek is suggested by both sets of contours. It may reflect a small density contrast between the Granite Creek pluton and the enclosing rocks. The gravity low in the area of Pittsburg Landing is probably caused by sedimentary rocks in the Kurry Creek Member of the Doyle Creek Formation. A gravity low in the Deep Creek area appears to correlate with the magnetic low in this area.

\section{Conclusions}

The magnetic field in the Hells Canyon area is complex with the most prominent highs related to basalt of the Columbia River Group and Mesozoic igneous rocks. Two magnetic anomalies indicate rocks with anomalous magnetization or geometry. The first is in the area of Sheep Creek (pl. 1) where a large magnetic high in the area of a quartz diorite pluton is produced by a strongly magnetized mass of considerable depth and extent. The second area is at Granite Creek (pl. 1) where a large magnetic high indicates strongly magnetized rock surrounding three sides of a quartz diorite pluton that is less strongly magnetized. An extensive mass of intrusive rock is indicated near the southern edge of the study area. Large masses of gabbro of Triassic-Jurassic age appear to extend under the basalt in the northern part of the study area. Magnetic lows near Deep Creek-Oxbow Creek and Johnson Bar (pl. 1) may indicate areas where extensive alteration has reduced the magnetization of rocks of the Seven Devils Group.

Only the regional features of the gravity field are defined by the sparse gravity data available. Two gravity highs reflect positive mass anomalies in the pre-Tertiary rocks but cannot be correlated with mapped geology. One of these gravity highs, in the Morgan Ridge area, is associated with a large magnetic high.

\section{Geothermal Energy}

\section{By George C. Simmons and Don R. Mabey}

The most common indicators of geothermal systems of potential economic significance are (1) late Tertiary or Quaternary volcanism - particularly silicic volcanism, (2) thermal springs and wells, and (3) above-normal geothermal gradient or heat flow. The Hells Canyon study area contains no upper Tertiary or Quaternary volcanic rocks, the youngest volcanic rocks being the Columbia River Basalt Group of Miocene 


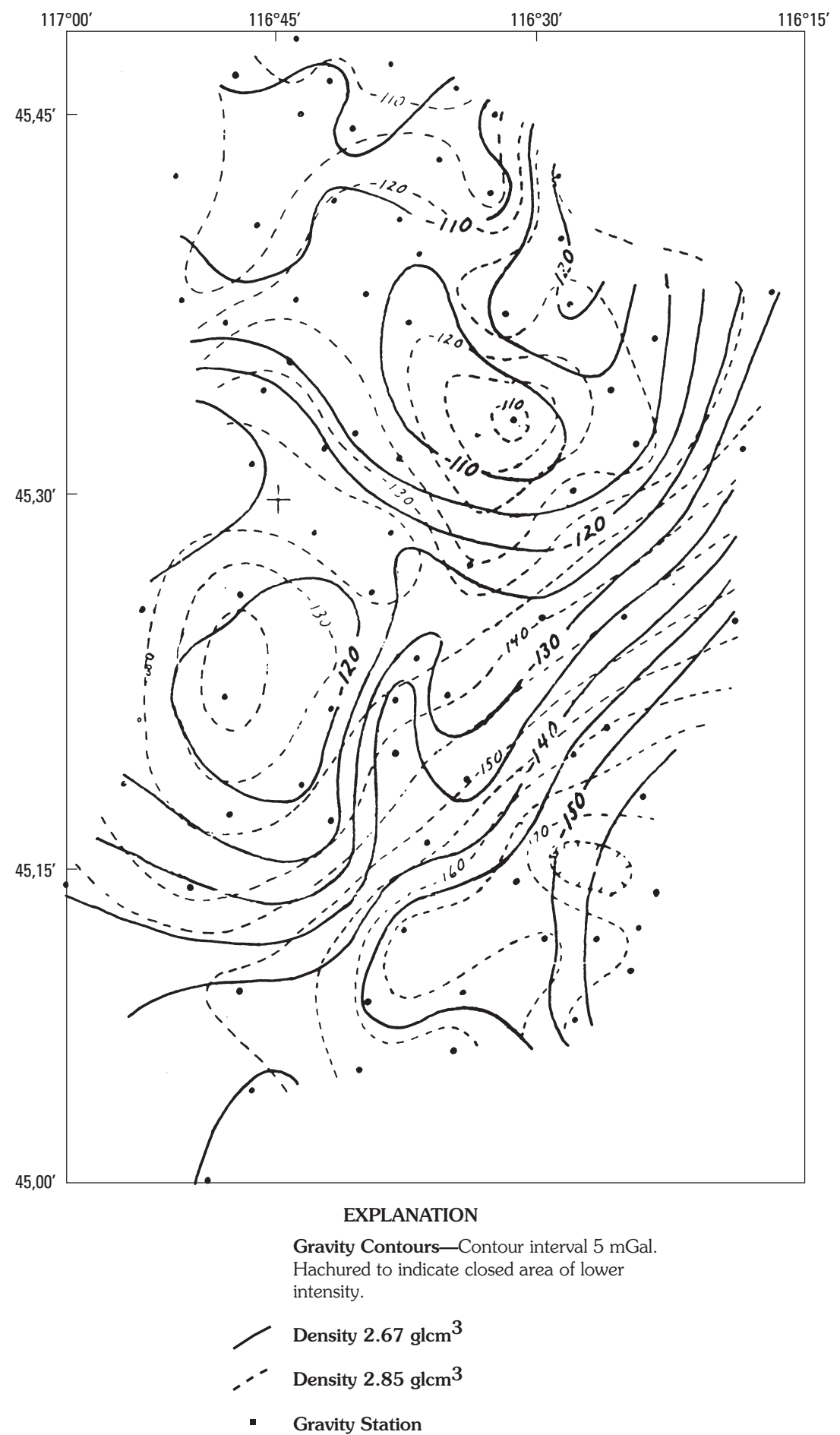

Figure 11. Complete Bouguer gravity anomaly map of Hells Canyon study area. 
(mid-Tertiary) age; only two thermal springs were found; and the measured heat flow in the south part of the study area is below the regional average.

Waters from the two springs were analyzed to determine reservoir temperatures using a sodium-potassium-calcium geothermometer. Sample localities are given in Simmons and others (1984). Sample HS 0079 was collected from a spring in alluvium, in a gully draining southwest toward the Snake River. The spring is about $100 \mathrm{ft}(30 \mathrm{~m})$ above and $500 \mathrm{ft}$ $(150 \mathrm{~m})$ east of the river, and is above the flood plain of the river. The temperature of the water was $29^{\circ} \mathrm{C}\left(84.2^{\circ} \mathrm{F}\right)$, and analyses indicate a reservoir temperature of $53.4^{\circ} \mathrm{C}\left(128.1^{\circ} \mathrm{F}\right)$. Sample HS 0430 was collected from a spring in alluvium about $50 \mathrm{ft}(15 \mathrm{~m})$ east and $3 \mathrm{ft}(1 \mathrm{~m})$ above Cook Creek. The temperature of the water was $38.2^{\circ} \mathrm{C}\left(100.8^{\circ} \mathrm{F}\right)$, and analyses indicate a reservoir temperature of $46.1^{\circ} \mathrm{C}\left(115^{\circ} \mathrm{F}\right)$.

The thermal gradient was measured in a drill hole in the southern part of the study area (Brott and others, 1976). The gradient in the interval between 49 to $95 \mathrm{~m}$ (161 to $312 \mathrm{ft})$ below the surface was $21^{\circ} \mathrm{C} / \mathrm{km}$, and the computed heat flow is 1.3 HFU. These values are much lower than in areas to the south and east where geothermal systems are known to exist.

The lack of young volcanic rocks, the scant number of thermal springs, the low temperatures of the reservoirs for the two springs that were found, and the low heat flow measured near the south boundary of the study area indicate that the potential for geothermal energy resources is low.

\section{Geochemistry}

A geochemical survey of the study area was made concurrently with the geological reconnaissance. A total of 5,268 samples were collected of which 4,757 were chemically analyzed and 135 were cut for thin sections to facilitate microscopic studies. The analyzed samples include 3,834 rock samples, 898 stream-sediment samples, 1 panned concentrate, 22 soil samples, and 2 water samples. The analytical data for all samples except the water samples are stored on a computer tape that can be obtained from U.S. Department of Commerce, National Technical Information Service, Springfield, VA, 22161, as catalog number PD83-255-059.

All samples except the water samples were analyzed by a 6-step, semiquantitative, spectrographic method (Grimes and Marranzino, 1968) for 20 elements: iron, calcium, titanium, manganese, silver, boron, beryllium, cadmium, cobalt, chromium, copper, molybdenum, nickel, lead, tin, strontium, vanadium, tungsten, zinc, and zirconium; 2,130 samples were analyzed by the same method for these 20 and an additional 10 elements: magnesium, arsenic, gold, barium, bismuth, lanthium, niobium, antimony, scandium, and yttrium; and 530 samples were analyzed in this manner for thorium.

Atomic absorption analyses were made of 77 samples of limestone to test their magnesium and calcium contents; of 502 stream-sediment and rock samples, and the panned concentrate, to test for gold; of 52 stream-sediment samples to test for silver, cadmium, and zinc; and of 54 stream-sediment samples to test for bismuth.

Mercury was tested in 1,534 rock samples by the instrument method.

All soil samples and 743 stream-sediment samples were analyzed by a colorimetric method for citrate-soluble combined cobalt, copper, lead, and zinc (Ward and others, 1963).

All rock samples were scanned for radioactivity with a scintillation counter, and 128 rock samples were checked radiometrically for equivalent $\mathrm{U}_{3} \mathrm{O}_{8}$.

The water samples were analyzed by wet methods for sodium, potassium, calcium, and silica to determine subsurface temperatures of the springs.

The localities of all samples for which chemical data exist appear in Simmons and others (1984, pls. 1-4). The types of samples are indicated by symbols, and each is identified by a number. Where two or more samples were collected from the same site, the additional samples are indicated by additional numbers or at some sites by letter suffixes.

Rock samples were collected throughout the study area to establish the normal background amounts of metals in different types of rocks, and to test for possible anomalies or anomalous trends. Samples were taken from hydrothermally altered rocks that might contain mineral deposits. Samples were collected from mines and prospect pits, not only to determine the quantity of metals in the visible ore minerals, but to discover what other elements occur in trace amounts and which might serve as indicators of undiscovered mineral occurrences.

Most stream-sediment samples were collected near the mouths of streams, just above the confluence with the streams into which they flow, and from the same position in some beds of nonflowing, intermittent streams. Many stream beds have steep gradients and occur in steep-sided canyons; on intermittent streams, the alluvium is mixed with colluvium from the stream banks - with the result that the sediments in those stream bottoms are not proportionally representative of the source rocks in the drainage basin.

The metal content of stream sediments has two sources: metal-bearing minerals can be intrinsic constituents of stream sediments, and metallic ions can be adsorbed from stream waters by iron and manganese precipitates on the surfaces of alluvial particles. Because small particles have greater surface areas per unit volume than do large particles, and consequently greater capacity to adsorb metal ions, stream-sediment samples were taken from the finest sediment available. Stream-sediment samples with anomalous metal contents are indicative of mineralized rock in the drainage basin of the stream bed in which they occur.

The determinations of anomalous values are based upon statistical comparisons of the variations of metal contents in similar lithologic units. Because the normal amounts of elements differ in different types of rocks, the analytical value at which the amount of any particular element is considered anomalous is not a single figure, and a value that is normal in one rock type may be 
anomalous in another. Slightly more than 15 percent of the geochemical samples are anomalous in the 5 elements of particular interest: silver, copper, molybdenum, lead, and zinc. Most values are near the threshold values - the lower limits at which each element is designated as being anomalous. These 5 elements, as well as 27 others of more limited interest because of their sparsity, are listed in table 3 together with their lower limits of detection and threshold values according to lithology.

Analyses of all samples containing anomalous amounts of silver, arsenic, gold, boron, barium, beryllium, bismuth, cadmium, cobalt, chromium, copper, lanthanum, molybdenum, niobium, nickel, lead, antimony, scandium, tin, strontium, vanadium, tungsten, yttrium, zinc, zirconium, thorium, mercury, or uranium are in Simmons and others (1984).

\section{Geochemical Occurrences of Elements}

Many trace elements are known to be concentrated in certain rock types in preference to others, and many generalities exist, such as copper being more abundant in basalt than in granite, or strontium being more abundant in limestone than in graywacke; high values of strontium may therefore only indicate the presence of limestone rather than a deposit of strontium. Furthermore, not only must high values of any particular element be considered according to the type of sample in which it occurs, but it must also be compared with other samples of its kind from the region in which it occurs. For example, copper is abundant in a wide variety of rock types throughout the region near Hells Canyon, and 100 ppm of copper is not considered to be anomalous in the granitic rocks there; however, this amount of copper would be anomalous in the granitic rocks of many regions. For this reason, anomalies were determined by comparing analyses of similar samples within the Hells Canyon study area (table 3).

An anomalous amount of a trace element is not necessarily evidence of an ore body. Many anomalous values simply represent normal variations of a rock's common chemical constituents; the Columbia River Basalt Group contains a number of such anomalies of copper, lead, and even silver near their threshold values of 300,15 , and $0.5 \mathrm{ppm}$, respectively, but none of these anomalies are indicative of mineralization. Also, anomalies may indicate mineral deposits that do not represent a resource.

On the other hand, anomalies or a combination of anomalies may indicate the presence of ore bodies, and any area where anomalies are concentrated is significant in this regard. Also, some minerals that often occur together in mineral deposits have different solubilities; zinc, for example, can migrate more readily from an ore deposit than lead. Thus, an anomaly of zinc may lead to the discovery of an ore body containing lead. Therefore, in determining the importance of an anomaly it is necessary to consider its relation to other anomalies, its level in regard to the rock type in which it occurs, and its relation to the geologic environment.
The only consistent pattern of associated trace elements in the Hells Canyon study area are those of silver, copper, molybdenum, lead, and zinc. Other associations are erratic, of too sparse occurrence, or involve anomalies of such low magnitude that they have no economic interest.

\section{Silver, Copper, Molybdenum, Lead, and Zinc}

Anomalies of silver, copper, molybdenum, lead, and zinc occur in stream sediments and a wide variety of rocks, and are sufficiently concentrated at many places to merit special interest. Wherever one of these metals is present in a highly anomalous amount, one or more of the other four are commonly anomalous also, and at a number of places anomalous amounts of all five elements occur together. For this reason it seems likely that if undiscovered ore bodies do exist, then more than one element might be commercially recoverable. Being thus linked, economically and by occurrence, silver, copper, molybdenum, lead, and zinc are discussed as a unit. Because the anomalies of the five metals are too numerous to discuss individually, only their general occurrence is considered here; the more significant groups of anomalies are described in the section on assessment of mineral resource potential.

Most areas containing groups of samples having anomalous amounts of silver, copper, molybdenum, lead, or zinc are underlain by volcanic rocks of the Seven Devils Group. These areas may overlie volcanogenic deposits, whether or not they are adjacent to intrusive plutons, which may have partly mobilized and redistributed the original metal concentrations.

Three areas with groups of samples containing anomalous amounts of metals are underlain by rocks other than the Seven Devils Group. One area is east of Rapid River (area 4, fig. 1) in schist and gneiss. The anomalies are mostly low values of zinc with a few low values of silver, lead, and molybdenum; copper is notably absent. Most of the samples are also anomalous in only one metal, and being of low values, would not be considered unusual were it not for their abundance. What type of mineral deposits these anomalies might represent is unknown.

The group of samples around White Monument (area 3, fig. 1) defines a second area along and near the contact of a granitic pluton with the Seven Devils Group, where limestone inclusions are present in the granitic rocks. Anomalies having high values in copper, silver, and molybdenum, and low values in zinc and tungsten, are associated with known tactite deposits. Other anomalies of copper, silver, molybdenum, and a few of lead and zinc may indicate other kinds of deposits-volcanogenic or disseminated deposits of granitic origin in the Seven Devils Group or disseminated or vein deposits in the granitic rocks.

The third area, near the mouth of the Imnaha River (area 20, fig. 1), is underlain by a pluton of gabbro, diorite, and quartz diorite. Most of the anomalous values are of copper; a few are of silver, molybdenum, and zinc. Most values are low and are indicative of the many small mineralized fissures in the pluton. 
Table 3. Threshold values for geochemical anomalies in samples from the Hells Canyon study area (partial list).

[Values given in parts per million. Lower limits of detection (in parentheses) determined by sensitivity of semiquantitative spectrographic analyses, except for gold—by atomic absorption; mercury — by mercury detector; and uranium (eU3O8) by radiometry; n.d., not determined. Sample descriptions: (1) stream sediments; (2) soil; (3) Miocene alluvium; (4) poorly indurated Miocene gravel (conglomerate); (5) arenaceous: graywacke, sandstone, conglomerate, and arkose; (6) argillaceous: mudstone, shale, argillite, and siltstone; (7) calcareous: limestone; (8) tuff; (9) acid: rhyolite; felsite; (10) intermediate: andesite, dacite, diorite, greenstone, tuff, breccia, agglomerate; (11) basic: basalt, greenstone, diabase, breccia, agglomerate; (12) basic: basalt, Columbia River Basalt Group; (13) quartz rich: alaskite, felsite, granodiorite, granite, quartz diorite; (14) intermediate, quartz-poor: diorite, latite, monzonite; (15) basic: gabbro, diabase; (16) quartz-rich: alaskite, felsite, aplite, rhyolite, granodiorite; (17) acid and intermediate, quartz-poor: andesite, diorite, epidiorite, monzonite, trachyte; (18) gneiss, migmatite; (19) schist; (20) amphibolite; (21) tactite; (22) hornfels, epidotite; (23) cataclastic rocks; (24) hydrothermally altered rocks; (25) gossan; (26) quartz veins, quartz lenses, and other veins]

\begin{tabular}{|c|c|c|c|c|c|c|c|c|}
\hline \multirow[b]{2}{*}{ Element } & \multicolumn{4}{|c|}{ Sediments } & \multicolumn{4}{|c|}{ Sedimentary rocks } \\
\hline & 1 & 2 & 3 & 4 & 5 & 6 & 7 & 8 \\
\hline Silver $(0.50)$ & 0.70 & 0.50 & 0.50 & 0.50 & 0.50 & 0.70 & 0.50 & 0.50 \\
\hline Arsenic (200) & 200 & n.d. & n.d. & 200 & 200 & 200 & 200 & 200 \\
\hline Gold (10) & 10 & n.d. & n.d. & 10 & 10 & 10 & 10 & 10 \\
\hline Boron (10) & 70 & 500 & 50 & 100 & 70 & 150 & 10 & 70 \\
\hline Barium (20) & 1,500 & n.d. & n.d. & 1,000 & 700 & 2,000 & 500 & 500 \\
\hline Beryllium (1.0) & 1.5 & 5.0 & 1.0 & 1.0 & 1.0 & 1.0 & 1.0 & 1.0 \\
\hline Bismuth (10) & 10 & n.d. & n.d. & 10 & 10 & 10 & 10 & 10 \\
\hline Cadmium (20) & 20 & 20 & 20 & 20 & 20 & 20 & 20 & 20 \\
\hline Cobalt (5.0) & 100 & 70 & 100 & 70 & 100 & 70 & 30 & 70 \\
\hline Chromium (10) & 200 & 100 & 200 & 200 & 200 & 200 & 50 & 150 \\
\hline Copper (5.0) & 200 & 200 & 200 & 200 & 200 & 200 & 70 & 200 \\
\hline Lanthanum (20) & 70 & n.d. & n.d. & 30 & 30 & 50 & 30 & 30 \\
\hline $\begin{array}{l}\text { Molybdenum } \\
\text { (5.0) }\end{array}$ & 5.0 & 10 & 5.0 & 5.0 & 5.0 & 7.0 & 5.0 & 5.0 \\
\hline Niobium (20) & 20 & n.d. & n.d. & 20 & 20 & 20 & 20 & 20 \\
\hline Nickel (5.0) & 150 & 70 & 150 & 100 & 100 & 100 & 50 & 100 \\
\hline Lead (10) & 50 & 50 & 50 & 20 & 15 & 20 & 10 & 15 \\
\hline Antimony (100) & 100 & n.d. & n.d. & 100 & 100 & 100 & 100 & 100 \\
\hline Scandium (5.0) & 100 & n.d. & n.d. & 50 & 70 & 70 & 50 & 70 \\
\hline $\operatorname{Tin}(10)$ & 10 & 10 & 10 & 10 & 10 & 10 & 10 & 10 \\
\hline Strontium (100) & 700 & 700 & 700 & 700 & 1,000 & 1,500 & 5,000 & 1,000 \\
\hline Vanadium (10) & 700 & 1,000 & 700 & 700 & 700 & 1,000 & 200 & 700 \\
\hline Tungsten (50) & 50 & 50 & 50 & 50 & 50 & 50 & 50 & 50 \\
\hline Yttrium (10) & 100 & n.d. & n.d. & 70 & 70 & 100 & 50 & 70 \\
\hline Zinc (200) & 200 & 300 & 200 & 200 & 200 & 200 & 200 & 200 \\
\hline Zirconium (10) & 500 & 500 & 500 & 300 & 200 & 300 & 50 & 300 \\
\hline Thorium (100) & 100 & n.d. & n.d. & n.d. & 100 & n.d & 100 & n.d. \\
\hline Gold (.05) & .05 & n.d. & .05 & .05 & .05 & n.d. & .05 & n.d. \\
\hline Mercury (.02) & .75 & .70 & n.d. & n.d. & .10 & .10 & .10 & n.d. \\
\hline Uranium (30) & n.d & n.d. & n.d. & n.d. & 30 & 30 & n.d. & n.d. \\
\hline
\end{tabular}


Table 3. Threshold values for geochemical anomalies in samples from the Hells Canyon study area (partial list)—Continued.

\begin{tabular}{|c|c|c|c|c|c|c|c|c|c|}
\hline \multirow[b]{4}{*}{ Element } & \multicolumn{9}{|c|}{ Igneous rocks } \\
\hline & \multicolumn{4}{|c|}{ Extrusive } & \multicolumn{5}{|c|}{ Intrusive } \\
\hline & \multirow[b]{2}{*}{9} & \multirow[b]{2}{*}{10} & \multirow[b]{2}{*}{11} & \multirow[b]{2}{*}{12} & \multicolumn{3}{|c|}{ Plutons } & \multicolumn{2}{|c|}{ Dikes and sills } \\
\hline & & & & & 13 & 14 & 15 & 16 & 17 \\
\hline Silver & 1.5 & 0.50 & 0.50 & 0.50 & 0.50 & 0.50 & 0.50 & 0.50 & 0.50 \\
\hline Arsenic & 200 & 200 & 200 & 200 & 200 & 200 & 200 & 200 & 200 \\
\hline Gold & 10 & 10 & 10 & 10 & 10 & 10 & 10 & 10 & 10 \\
\hline Boron & 100 & 50 & 50 & 15 & 30 & 50 & 30 & 50 & 50 \\
\hline Barium & 1,000 & 1,000 & 700 & 1,500 & 700 & 500 & 500 & 700 & 1,000 \\
\hline Beryllium & 2.0 & 1.5 & 1.0 & 1.0 & 1.0 & 1.0 & 1.0 & 2.0 & 1.0 \\
\hline Bismuth & 10 & 10 & 10 & 10 & 10 & 10 & 10 & 10 & 10 \\
\hline Cadmium & 20 & 20 & 20 & 20 & 20 & 20 & 20 & 20 & 20 \\
\hline Cobalt & 50 & 100 & 100 & 100 & 50 & 70 & 100 & 100 & 70 \\
\hline Chromium & 200 & 300 & 300 & 150 & 200 & 300 & 500 & 200 & 300 \\
\hline Copper & 200 & 300 & 300 & 300 & 150 & 200 & 200 & 150 & 300 \\
\hline Lanthanum & 50 & 50 & 50 & 50 & 30 & 30 & 30 & 50 & 50 \\
\hline Molybdenum & 5.0 & 5.0 & 5.0 & 5.0 & 5.0 & 5.0 & 5.0 & 5.0 & 5.0 \\
\hline Niobium & 20 & 20 & 20 & 20 & 20 & 20 & 20 & 20 & 20 \\
\hline Nickel & 70 & 150 & 150 & 150 & 100 & 150 & 200 & 100 & 150 \\
\hline Lead & 30 & 15 & 15 & 15 & 10 & 10 & 10 & 15 & 15 \\
\hline Antimony & 100 & 100 & 100 & 100 & 100 & 100 & 100 & 100 & 100 \\
\hline Scandium & 50 & 70 & 100 & 70 & 70 & 70 & 50 & 100 & 70 \\
\hline Tin & 10 & 10 & 10 & 10 & 10 & 10 & 10 & 10 & 10 \\
\hline Strontium & 500 & 1,000 & 700 & 700 & 1,500 & 1,000 & 700 & 1,000 & 2,000 \\
\hline Vanadium & 700 & 700 & 700 & 700 & 500 & 700 & 700 & 500 & 700 \\
\hline Tungsten & 50 & 50 & 50 & 50 & 50 & 50 & 50 & 50 & 50 \\
\hline Yttrium & 50 & 100 & 100 & 100 & 70 & 70 & 70 & 70 & 70 \\
\hline Zinc & 200 & 200 & 200 & 200 & 200 & 200 & 200 & 200 & 200 \\
\hline Zirconium & 1000 & 300 & 300 & 500 & 300 & 300 & 300 & 500 & 200 \\
\hline Thorium & n.d. & 100 & 100 & 100 & 100 & 100 & 10 & 100 & 100 \\
\hline Gold & .05 & .05 & .05 & .05 & .05 & .05 & n.d. & n.d. & n.d. \\
\hline Mercury & .10 & .10 & .10 & .20 & .10 & .10 & .10 & .10 & .10 \\
\hline Uranium & n.d. & 30 & 30 & n.d. & 30 & 30 & n.d. & 30 & 30 \\
\hline
\end{tabular}


Table 3. Threshold values for geochemical anomalies in samples from the Hells Canyon study area (partial list) — Continued.

\begin{tabular}{|c|c|c|c|c|c|c|c|c|c|}
\hline \multirow[b]{2}{*}{ Element } & \multicolumn{9}{|c|}{ Metamorphic rocks } \\
\hline & 18 & 19 & 20 & 21 & 22 & 23 & 24 & 25 & 26 \\
\hline Silver & 0.70 & 0.70 & 0.50 & 0.50 & 0.50 & 0.50 & 1.5 & 5.0 & 0.50 \\
\hline Arsenic & 200 & 200 & 200 & n.d. & 200 & n.d. & 200 & n.d. & 200 \\
\hline Gold & 10 & 10 & 10 & n.d. & 10 & 10 & 10 & n.d. & 10 \\
\hline Boron & 30 & 200 & 20 & 20 & 150 & 30 & 30 & 50 & 150 \\
\hline Barium & 500 & 1,000 & 300 & n.d. & 150 & n.d. & 1,000 & n.d. & 300 \\
\hline Beryllium & 1.5 & 1.5 & 1.0 & 1.0 & 1.0 & 1.0 & 1.5 & 1.0 & 1.0 \\
\hline Bismuth & 10 & 10 & 10 & 10 & 10 & n.d. & 10 & 10 & 10 \\
\hline Cadmium & 20 & 20 & 20 & 20 & 20 & 20 & 20 & 20 & 20 \\
\hline Cobalt & 50 & 70 & 100 & 50 & 70 & 100 & 70 & 70 & 50 \\
\hline Chromium & 150 & 500 & 300 & 70 & 300 & 700 & 200 & 100 & 50 \\
\hline Copper & 150 & 300 & 200 & 500 & 500 & 300 & 300 & 2,000 & 3,000 \\
\hline Lanthanum & 30 & 30 & 30 & n.d. & 30 & n.d. & 50 & n.d. & 30 \\
\hline Molybdenum & 5.0 & 15 & 5.0 & 5.0 & 5.0 & 5.0 & 15 & 50 & 5.0 \\
\hline Niobium & 20 & 20 & 20 & n.d. & 20 & n.d. & 20 & n.d. & 20 \\
\hline Nickel & 50 & 200 & 100 & 70 & 200 & 200 & 100 & 100 & 70 \\
\hline Lead & 15 & 30 & 10 & 15 & 30 & 10 & 30 & 100 & 10 \\
\hline Antimony & 100 & 100 & 100 & n.d. & 100 & n.d. & 100 & n.d. & 100 \\
\hline Scandium & 100 & 70 & 50 & n.d. & 50 & n.d. & 70 & n.d. & 30 \\
\hline Tin & 10 & 10 & 10 & 10 & 10 & 10 & 10 & 10 & 10 \\
\hline Strontium & 1,500 & 1,500 & 1,500 & 500 & 2,000 & 1,000 & 1,000 & 150 & 500 \\
\hline Vanadium & 700 & 1,000 & 1,000 & 1,000 & 1,000 & 700 & 700 & 300 & 700 \\
\hline Tungsten & 50 & 50 & 50 & 50 & 50 & 50 & 50 & 50 & 50 \\
\hline Yttrium & 100 & 70 & 70 & n.d. & 70 & n.d. & 70 & n.d. & 50 \\
\hline Zinc & 200 & 200 & 200 & 200 & 200 & 200 & 200 & 500 & 200 \\
\hline Zirconium & 300 & 300 & 200 & 200 & 200 & 300 & 500 & 200 & 200 \\
\hline Thorium & n.d. & n.d. & n.d. & n.d. & n.d. & n.d. & 100 & n.d. & n.d. \\
\hline Gold & n.d. & .05 & n.d. & n.d. & n.d. & n.d. & .05 & .05 & n.d. \\
\hline Mercury & .10 & .10 & .10 & .10 & .10 & n.d. & .10 & .10 & n.d. \\
\hline Uranium & n.d. & n.d. & n.d. & n.d. & n.d. & n.d. & 30 & n.d. & n.d \\
\hline
\end{tabular}




\section{Gold}

Gold was detected in only nine samples (table 4). Three of these are rock samples from quartz veins that were prospected for gold, one is a panned-concentrate sample from an area long known to contain placer gold, and four are streamsediment samples. In the rock samples, the gold occurs with trace amounts of silver, and although little gold was found during the sampling program, production records from mines in the area indicate that wherever gold was present in vein deposits, some silver was present also.

Sample HS 0090 is a stream-sediment sample from near the mouth of Bull Creek (pl. 1). Besides gold, the sample also contains an anomalous amount of barium (5,000 ppm), but has no other anomalous values of metals. A few low anomalous values of metals were found in nearby rocks of the Seven Devils Group, but no gold was detected in them. The streamsediment sample is considered an odd occurrence of no particular significance.

Sample HW 0030 is a stream-sediment sample from Deep Creek, collected just above its confluence with Oxbow Creek (pl. 1). In addition to gold, the sample contains anomalous amounts of silver (1 ppm) and copper (300 ppm). This association of metals is common at the Red Ledge mine, a volcanogenic deposit about $1 \mathrm{mi}(1.6 \mathrm{~km})$ from the sample site in the drainage of Deep Creek. However, the same three metals occur together in other types of deposits in the study area.

Samples HP 0137, HP 0138, and HP 0139 are streamsediment samples collected near the mouths of small tributaries to Somers Creek (pl. 2). In addition to gold, HP 0137 and HP 0138 contain anomalous amounts of silver, copper, lead, and zinc. This suite of metals is common in volcanogenic deposits in the Hells Canyon area, although gold is rarely detected in geochemical stream-sediment samples.

\section{Arsenic, Bismuth, and Antimony}

Arsenic, bismuth, and antimony are geochemically similar elements that are sometimes useful indicators because of their association with gold, silver, copper, molybdenum, lead, and zinc. Arsenic is commercially produced as a byproduct of smoke during smelting of ores; most bismuth is obtained during the refining of ores of other metals, few deposits being mined for bismuth alone; most antimony is produced from lead and stibnite (antimony sulfide) ores. Arsenic, bismuth, and antimony in the Hells Canyon study area are much more restricted in distribution than the noble and base metals whose presence they might indicate elsewhere, and their concentrations are too low to suggest that they are commercially recoverable. Only two samples contained arsenic and antimony at or above threshold values, and 11 samples contained bismuth at or above the threshold value. With two exceptions, all of these samples are from mines, prospect pits, and previously known tactite zones and mineralized areas. The two exceptions, HG 1020 and HG 1026 contain bismuth at its threshold value (10 ppm); HG 1020 also contains zinc at its threshold value (200 ppm), and HG 1026 has a low, anomalous value of molybdenum (10 ppm). Both samples are from quartz-amphibole schist in the drainage of North Star Creek.

\section{Barium}

The mineral barite (barium sulfate, $\mathrm{BaSO}_{4}$ ) is the only major source of barium. This mineral is mined from fissure and breccia fillings, replacement deposits, bedded deposits of probable sedimentary origin, and from residual deposits derived from the weathering of other kinds of deposits. Barium is more abundant in argillaceous sedimentary rocks in the Seven Devils Group than in other rocks in the Hells Canyon study area, but the miniscule amounts - the maximum concentration was $3,000 \mathrm{ppm}$ in one sample-do not suggest the presence of mineral resources.

Barite commonly occurs as a gangue mineral in veins bearing metallic minerals, and is therefore of potential use as a guide to mineral deposits. However, the barium content of veins in the study area is very low: the maximum found was $200 \mathrm{ppm}$ in one sample. Because the ordinary amounts of barium in many rock types exceed this quantity, the element was useless as a guide.

\section{Beryllium}

The presence of beryllium is at some places indicative of pneumatolytic activity near the margins of plutons; hence, this element can serve as a guide to mineralized areas. Metallic beryllium is produced from beryl (beryllium-aluminum silicate $\left(\mathrm{Be}_{3} \mathrm{Al}_{2}\left(\mathrm{SiO}_{3}\right)_{6}\right)$, whose principal occurrence is in granite pegmatites. Beryl is rare in pegmatites near Hells Canyon and the beryllium content of all rocks is low throughout the study area. The highest concentration of beryllium, $5 \mathrm{ppm}$, was found in a few stream-sediment and soil samples. The element is slightly concentrated in altered rocks, but the concentration is weak: a maximum of $3 \mathrm{ppm}$ being found in one sample. Hence, beryllium was of little use as a guide to mineralized areas.

\section{Boron}

Boron is commercially obtained from brines and evaporite deposits associated with saline lakes and from thermal springs and fumaroles associated with recent volcanic activity. Because these conditions do not exist in the study area, the possibility of resources of boron is nonexistent. Trace amounts of this element occur in most rocks in the region of Hells Canyon; that is of some interest because boron can indicate areas that may contain other metallic deposits. Concentrations of boron can indicate pneumatolytic activity near the margins of plutons or the presence of mineralizing solutions in volcanic rocks. In this regard, boron was more useful than beryllium as a consequence of its greater distribution and slight tendency to be concentrated near or with anomalous amounts of silver and copper, particularly in areas containing hydrothermally altered rocks. 
Table 4. Samples containing anomalous amounts of gold from the Hells Canyon study area.

[Grid coordinates are from Simmons and others (1984)]

\begin{tabular}{llcc}
\hline \multicolumn{1}{c}{ Sample no. } & \multicolumn{1}{c}{ Sample type } & Grid coordinates & Gold (ppm) \\
\hline HA 0147 & $\begin{array}{l}\text { Quartz vein in Seven Devils Group, from } \\
\text { prospect pit }\end{array}$ & X28-Y20 & 1.7 \\
HA 0643 & $\begin{array}{l}\text { Panned concentrate of Miocene gravel. } \\
\text { Quartz vein in Seven Devils Group, from } \\
\text { prospect pit. }\end{array}$ & X28-Y24 & X27-Y20 \\
HG 0837 & $\begin{array}{l}\text { Quartz from vein in Seven Devils Group, } \\
\text { from stockpile at prospect pit. }\end{array}$ & X27-Y20 & 9 \\
HP 0137 & Stream sediment & & .9 \\
HP 0138 & do & & .25 \\
HP 0139 & do & & .10 \\
HS 009 & do & & .7 \\
HW 0030 & do & & .15 \\
\end{tabular}

\section{Cadmium}

Cadmium is a secondary product, produced almost entirely from the smelting of zinc ores, and nowhere occurs in sufficient concentrations to be mined for itself alone. The chief use of cadmium as a trace element is to indicate the presence of high concentrations of zinc, but in the Hells Canyon study area it was found in only nine samples, all at low values (20-300 ppm); the highest of these values were in samples collected at the Blue Jacket mine and prospect pits. With one exception, all samples containing cadmium also contained much larger amounts of zinc and other metals, and these eight samples are discussed under other headings. The exception, HS 0851 (pl. 2 of Simmons and others, 1984), is from a diorite dike in the Seven Devils Group on the ridge between Granite Creek and the Snake River; the sample contains cadmium at its threshold value (20 ppm), but contains no anomalous values of other metals and does not indicate any mineral concentration.

\section{Chromium}

All known deposits of chromium are magmatic segregations in ultrabasic plutonic rocks, and because such rocks have not been recognized in the study area, the possibility of chromium deposits being present is very low. Within the study area, chromium is most abundant in intermediate and basic extrusive rocks of the Seven Devils Group, but among 4,755 samples tested for chromium, including 1,596 samples of intermediate and basic extrusive rocks of the Seven Devils Group, the highest value determined was only 1,000 ppm; this small quantity was found in only five samples and, in conjunction with the lack of ultrabasic rocks, suggests a lack of chromium deposits.

\section{Cobalt and Nickel}

The small amounts of cobalt and nickel, even where most highly concentrated, and the lack of favorable geologic conditions suggest little likelihood of deposits of these metals. Cobalt is obtained as a byproduct from copper and silver ores and from weathered residuum associated with copper deposits; nickel is produced from replacement and magmatic injection deposits of nickel-copper sulfide and from residual concentrations in weathered ultrabasic rocks. The few parts per million of cobalt and nickel associated with copper and nickel and the absence of ultrabasic rocks, combined with the lack of deep weathering necessary to produce residual deposits, indicate that cobalt and nickel do not constitute a resource in the study area.

\section{Lanthanum, Scandium, and Yttrium}

The rare earth metals, lanthanum, scandium, and yttrium, occur in trace amounts with little variation in different lithologies, although they are slightly more abundant in alluvium and arenaceous rocks than in other sediments and rocks. The restricted distribution of anomalous amounts of these elements and the erratic association of anomalous amounts of them with concentrations of other elements preclude their usefulness as guides to mineralized areas, and they do not occur in sufficient concentration to constitute a resource.

\section{Mercury}

Mercury deposits are formed by hydrothermal solutions at low temperatures in any kind of rocks that have been fractured and are associated with Cenozoic volcanism. Although the pre-Tertiary rocks in the study area are thoroughly fractured, and the area was almost entirely inundated by basalt flows of Cenozoic (Miocene) age, little 
hydrothermal activity accompanied the volcanism, and little likelihood of mercury deposits exists.

The great sensitivity of the mercury detector records amounts well below the average quantity of that element in the Earth's crust. It is therefore not surprising that mercury was detected in all but one of the 1,325 samples tested, and measurable amounts (that is, at threshold value $0.02 \mathrm{ppm}$ and above) were found in 733 samples. Although a number of the samples contain statistically anomalous amounts of mercury, the general values are too low to be considered geologically anomalous. With the exception of two rock samples from mine dumps, the highest value detected was $3 \mathrm{ppm}$ in a stream-sediment sample.

\section{Niobium}

Measurable amounts of niobium were found in only five samples, and these contained niobium at the threshold value of $20 \mathrm{ppm}$. Hence, niobium does not constitute a resource in the study area, nor was it useful in locating mineral deposits.

\section{Strontium}

Strontium is commercially obtained from celestite (strontium sulfate, $\mathrm{SrSO}_{4}$ ) and strontianite (strontium carbonate, $\mathrm{SrCO}_{3}$ ). Celestite occurs in sedimentary beds containing gypsum, disseminated in limestone, and in limestone cavities; celestite also occurs as gangue in veins containing metallic minerals, particularly galena, and hence can indicate the presence of lead. Strontianite occurs as replacements in limestone and as an alteration product of celestite.

Strontium was found in most samples analyzed during the present study, but apparently is not present in sufficient concentration to form visible minerals, and its mineralogy is unknown. The element is concentrated in limestones, and nine of the 130 limestone samples analyzed contained 5,000 ppm or more. Like barium, the amounts of strontium found in samples from veins were less than the ordinary amounts found in many rock types, and the element was useless as a guide to metallic deposits.

\section{Tin}

Tin is mined from stockwork and fissure vein deposits, disseminated replacement deposits, and placer deposits derived from the lode deposits. The lode deposits are formed by pneumatolytic action in association with silicic plutons, mostly granites. Exclusive of mineral deposits, tin is more abundant in granite than in any other rock.

The general abundance of tin in the Hells Canyon study area is very low, and measurable amounts of tin were found in only 14 samples (table 5). The spatial and geologic distribution of the samples and the low values (10-20 ppm) of 11 of the samples indicate little likelihood for the presence of any deposits. Five of the samples, HA 0252, HA 0387, HC 0087,
HG 0828, and HR 0237, contain anomalous amounts of copper, molybdenum, or lead, and all except HR 0237 occur in areas having a moderate potential for volcanogenic deposits of the latter metals, an unlikely environment for tin deposits.

\section{Tungsten}

Tungsten resembles tin in that it is found in or near granitic rocks and is concentrated in lode deposits formed by pneumatolytic or hydrothermal emanations. Tungsten was mined from small lode deposits of this kind in the Hells Canyon study area; traces of tungsten were found in three samples near the old mines - the only ones found to contain measurable amounts of tungsten. Samples HG 1134, HS 0856, and HS 0897 contain 500, 100, and 500 ppm of tungsten, respectively (pl. 3 of Simmons and others, 1984), and also contain anomalous amounts of silver, bismuth, and molybdenum.

\section{Uranium and Thorium}

The uranium and thorium content of rocks in the study area is very low. All samples were scanned for radioactivity with a scintillation counter, and none was detected above the background count. Of the 128 rock samples radiometrically checked for equivalent $\mathrm{U}_{3} \mathrm{O}_{8}$, only five were recorded at the threshold value $(30 \mathrm{ppm})$; all others were below that amount. The five samples are from the same area (pl. 4 of Simmons and others, 1984), and include HC 0364, a carbonaceous mudstone, and HG 0580, a carbonaceous siltstone, both from the Coon Hollow Formation. Samples HC 0366 and HG 0596 are from diorite sills in the Coon Hollow Formation; HW 0401 is from an andesite sill in the same formation. No detectable thorium was found in any of the 581 samples that were spectrographically analyzed.

\section{Vanadium}

Minable vanadium occurs in a variety of geologic environments, including magnetite deposits, hydrothermal veins, epigenetic deposits in sandstone and in the oxidized parts of base metal deposits, in asphaltite, and in altered rocks adjacent to alkalic intrusive bodies. Of these, hydrothermal veins and magnetite deposits are present in the study area.

Vanadium-bearing magnetite deposits occur in layered and complex intrusives of basic rocks. The plutonic body of gabbro near the mouth of the Imnaha River contains disseminated magnetite and magnetite along numerous small fissures. However, not only do the modes of occurrence differ from known vanadium-bearing magnetite deposits, but the vanadium content is low-a maximum of $500 \mathrm{ppm}$ was found in one sample. Hydrothermal veins in the study area also have a low content of vanadium-a maximum of $1,000 \mathrm{ppm}$ was found in only one sample. 


\section{Zirconium}

Commercial zirconium is obtained from two minerals, zircon (zirconium silicate, $\mathrm{ZrSiO}_{4}$ ) and baddeleyite (zirconium dioxide, $\mathrm{ZrO}_{2}$ ). Zircon is a common accessory mineral in igneous rocks, whereas baddeleyite is rare. With the exception of the Pocos de Caldas region in Brazil where zircon and baddeleyite are obtained from lode deposits in nepheline-bearing rocks and from placer deposits, all zirconium is obtained from zircon-bearing placer deposits. Neither nepheline-bearing rocks nor baddeleyite have been found in the study area, and zircon, although ubiquitous, is too scarce to constitute a resource. The highest concentration of zirconium was found in three stream-sediment samples, which contain more than $1,000 \mathrm{ppm}$; several samples of rhyolite and of hydrothermally altered rocks contain $700 \mathrm{ppm}$ of zirconium.

\section{Mineral Resources}

\section{Regional Setting}

Parts of the Hells Canyon study area are in several previously described mineral belts. The southwest part of the area is just within the Blue Mountains gold belt of Lindgren (1901) and the Snake River copper district of Swartley (1914). All of the study area in Idaho is in the Snake River copper belt of Livingston and Laney (1920), an area they show to extend from near the latitude of Huntington, Oreg., to north of the confluence of the Grande Ronde River with the Snake River; their belt is more or less co-extensive with exposures of the Seven Devils Group. Lindgren also cited the presence of copper deposits in greenstone and metavolcanic rocks in the
Blue Mountain gold belt, and noted that the deposits were more abundant in the east part of the belt where he described a few deposits. The consensus of previous observations would suggest that the region of northeast Oregon and extreme westcentral Idaho, which includes the Hells Canyon study area, is one of overlapping copper and gold provinces. However, the deposits of the two metals are spatially separate, and the characteristics of the deposits are so dissimilar that they are regarded as being genetically distinct (Lindgren, 1901, p. 632). A distinction is likewise made among copper deposits, some being confined to or intimately associated with plutonic rocks, whereas others occur in metavolcanic rocks (Lindgren, 1900, p. 49-253; Livingston and Laney, 1920, p. 57-82; Cook, 1954, p. 12-14; Libbey, 1943).

Regionally, copper and gold deposits are sparsely disseminated in the mineral belt; in the Hells Canyon study area, most occur toward the south. With the exception of the plutonrelated occurrences near the mouth of the Imnaha River (pl. 2), only minor occurrences of copper are known north of the shear zone near Temperance Creek (pl. 2). The gold occurrences are concentrated near Black Lake and Carbonate Hill (pl. 1).

\section{Copper Lode Deposits}

Copper deposits in and near the study area have been categorized in various ways by Lindgren (1901), Livingston and Laney (1920), and Cook (1954), but in general they distinguished between occurrences in metavolcanic rocks-either associated with structural features or with favorable lithologies-and those in tactite zones, formed at contacts of limestone inclusions in granitic rocks. Other types of copper deposits in the study area include copper-bearing veins (Livingston and

Table 5. Samples containing anomalous amounts of tin from the Hells Canyon study area.

[Plate numbers and grid coordinates from Simmons and others (1984)]

\begin{tabular}{llll}
\hline Sample no. & \multicolumn{1}{c}{ Sample type } & $\begin{array}{c}\text { Plate no. and grid } \\
\text { coordinates }\end{array}$ & Tin (ppm) \\
\hline HA 0082 & Limestone in Seven Devils Group & pl. 2; X29-Y26 & 10 \\
HA 0086 & Greenstone in Seven Devils Group & pl. 2; X29-Y26 & 15 \\
HA 0137 & Diorite pluton & pl. 2; X26-Y22 & 15 \\
HA 0252 & Stream sediment & pl. 1; X28-Y17 & 50 \\
HA 0387 & Meta-andesite in Seven Devils Group & pl. 1; X22-Y13 & 150 \\
HC 0087 & Silicified volcanic rock in Seven Devils Group & pl. 2; X26-Y26 & 15 \\
HG 0203 & Altered volcanic rock in Seven Devils Group & pl. 2; X26-Y27 & 10 \\
HG 0221 & Altered volcanic rock in Seven Devils Group & pl. 2; X27-Y27 & 10 \\
HG 0654 & Quartz vein & pl. 3; X31-Y35 & 20 \\
HG 0675 & Alaskite pluton & pl. 3; X31-Y32 & 15 \\
HG 0828 & Stream sediment & pl. 2; X27-Y20 & 20 \\
HG 0908 & Stream sediment & pl. 2; X30-Y22 & 15 \\
HR 0237 & Greenstone in Seven Devils Group & pl. 1; X28-Y16 & 200 \\
HS 0036 & Metavolcanic rock in Seven Devils Group & pl. 1; X23-Y17 & 20 \\
\hline
\end{tabular}


Laney, 1920, p. 37-38), and copper-bearing shear zones in plutonic rocks (Libbey, 1943).

Most copper deposits in and near the study area are in metavolcanic rocks and are in or closely associated with sheared, fractured, or faulted rock (Livingston and Laney, 1920, p. 28; Vallier and Brooks, 1970, p. 45-46). These deposits, which are morphologically distinct from the massive or large disseminated copper deposits of the region, have been categorized as mineralized shear zones by Livingston and Laney (1920, p. 28-41). However, they also (p. 40) included in this class of deposits certain gold veins and a vein-like body of disseminated copper. Ore minerals in these deposits are irregularly distributed and commonly are associated with some quartz. The mineralized material either fills open fractures or replaces wall rock. Primary ore minerals include chalcopyrite, bornite, galena, sphalerite, and tetrahedrite; chalcocite in most deposits probably also belongs in this group. Pyrite occurs in many deposits and in some may be auriferous. In deposits where supergene enrichment has taken place, covellite, cuprite, malachite, and azurite have formed (Livingston and Laney, 1920, p. 40-41). Native copper is reported associated with chalcocite in some of these deposits (Lindgren, 1901, p. 630), but none was observed during this study. Little alteration occurs in adjacent rocks. Gangue minerals, in addition to quartz, include calcite and barite. Most of the structures with which these deposits are associated strike northeast.

A massive copper sulfide deposit occurs near Homestead, Oreg., about $3 \mathrm{mi}(4.8 \mathrm{~km})$ southwest of the study area, and a large disseminated deposit occurs near Cuprum, Idaho, about $1 \mathrm{mi}(1.6 \mathrm{~km})$ south of the study area. Another large disseminated deposit, the Red Ledge, is on Deep Creek, near its confluence with Oxbow Creek (pl. 1). These deposits differ from the vein-like deposits in size and distribution of ore minerals, although fault-related structures-fractures, shear planes, and crushed zones-are also reported to have controlled or localized mineralization in the massive and disseminated deposits (Livingston and Laney, 1920, p. 53; Vallier and Brooks, 1970, p. 47-51). Furthermore, the suite of ore minerals in all the deposits is similar. Rock alteration, however, is different in the two types of deposits. Parts of the rocks adjoining the massive chalcopyrite and pyrite in the Homestead deposit have undergone silicic alteration (Swartley, 1914, p. 109). Argillic, sericitic, and potassic alteration are reported in the Red Ledge deposit (Livingston and Laney, 1920, p. 47-48); sericite as coarse as 0.5 in. $(1.3 \mathrm{~cm})$, orthoclase, and quartz have developed in host rock surrounding the deposit. Pervasive silicic alteration was observed up-canyon from the deposit during this study. The Red Ledge may differ from other deposits in that it is mostly in or associated with rhyolite, and may be loosely regarded as stratabound. The disseminated body near Cuprum may be similarly situated, but in andesite rather than rhyolite.

All copper deposits of the Snake River region studied by Lindgren (1901, p. 632), with the exception of the contact metamorphic type, were considered by him to have formed metasomatically, from the effect of regional metamorphism. He considered the copper to have come from the adjacent metavolcanic rocks. Livingston and Laney (1920) did not propose a mode of formation or source for the many shear zone deposits. They considered the Red Ledge to be a hypogenetic deposit derived from the granitic pluton at the head of Deep Creek, and recognized two episodes of mineralization, an earlier one during which pyrite was deposited, and a later one during which copper and other metals were deposited. Swartley (1914, p. 109) likewise believed that the Homestead deposit was derived from a plutonic source, but only in part. He believed that the original deposit contained gold and silver, and possibly some copper. According to Swartley, subsequent shearing permitted the introduction of thermal solutions, which concentrated any copper that had been deposited during the first period of mineralization and brought additional copper from the wall rocks to form a massive sulfide deposit. The massive and disseminated copper sulfide deposits are now generally regarded as volcanogenic, and hence essentially syngenetic with the host rocks. Structural associations and some (but not all) epigenetic characteristics are attributed to remobilization, which most likely took place when the region underwent low-grade metamorphism. The shear zone deposits may have formed by partial mobilization of copper and other metals in disseminated and massive sulfide deposits, the metals migrating along accessible structures to the sites in which they are now found. Deposits of copper and other metals in tactite, formed at the contact of limestone and granitic rock, were recognized as distinct from other types of copper deposits by Lindgren (1901, p. 629), who had previously seen and reported the contact deposits in the south part of the study area (1900, p. 251). The deposits were subsequently studied by Livingston and Laney (1920, p. 57-82) and Cook (1954, p. 12-19). The deposits, originally worked for copper, were later mined for tungsten.

All of the contact deposits are associated with the Jurassic and Cretaceous granitic pluton (KJgd) between Indian and Deep Creeks (pl. 1). The ore bodies are scattered in tactite, which has totally replaced or formed complete or partial envelopes around limestone. The ore bodies are irregular masses, typical of this type of ore body. Original minerals include bornite, chalcopyrite, galena, molybdenite, and tetrahedrite (Livingston and Laney, 1920, p. 66). Where supergene alteration took place, azurite, malachite, chalcanthite, anglesite, cerussite, and molybdite developed in the oxidized zone, and bornite, covellite, and chalcocite developed in the enriched zone (Livingston and Laney, 1920, p. 66-67). In deposits containing tungsten, the ore minerals include scheelite and powellite, and Cook (1954) believed that tungsten mineralization occurred prior to copper mineralization.

Sparse quartz-copper veins associated with pegmatite or aplite occur in the granitic pluton between Deep and Indian Creeks (Livingston and Laney, 1920, p. 37-39; W.H. White, 1968, p. 89). The veins range from a few inches to $2 \mathrm{ft}$ $(0.6 \mathrm{~m})$ in width and are in joints. Sulfide minerals including chalcopyrite, bornite, a little pyrite, and a silver-bearing 
mineral occur sporadically in irregular masses along the veins. Original ore minerals are altered to chalcocite and covellite in places. The wall rock is little altered. The veins are reported to strike northwest with low dips to the southwest (Livingston and Laney, 1920, p. 38); their attitude reflects that of the joints in which they occur. According to W. H. White (1968, p 8889 ), the joints developed parallel to the platy flow structure in the pluton.

Copper-bearing magnetite-hematite veins occur in shear zones in a diorite-gabbro pluton near the mouth of the Imnaha River (pl. 2). The veins were studied by Libbey (1943) whose observations are paraphrased here. The veins contain magnetite, specular hematite, and small amounts of quartz, pyrite, and chalcopyrite. They are commonly only a few inches in width, but in places are as much as $3 \mathrm{ft}(0.9 \mathrm{~m})$ wide. Locally, multiple veins occur separated by narrow widths of country rock. Chalcopyrite is scattered in the veins as irregular masses of little extent. Oxidized copper minerals, chalcanthite and malachite, have developed where chalcopyrite occurs near the surface or has been exposed in workings. Wall rock is intensely altered locally. Libbey (1943, p. 6) observed that the veins occur in two steeply dipping sets, one striking northeast and the other striking northwest. He considered the northeaststriking set to contain more numerous and persistent veins, whereas the northwest-striking set he thought to contain a higher percentage of copper.

The presence of magnetite in the veins and altered plutonic rock (Morrison, 1963, p. 171) is clearly evident on the aeromagnetic map (U.S. Geological Survey, 1980) where the contours indicate a magnetic high with steep relief.

Altered greenstone occurs discontinuously in a northeasttrending belt between the Triassic-Jurassic granitic pluton on Sheep Creek and the shear zone near Temperance Creek. The altered rock is argillized or silicified in places, and most of it is conspicuously bleached and stained by limonite. Minor occurrences of copper have been prospected or mined at several places in this belt where the metavolcanic rocks have been sheared. In some places, copper minerals are associated with quartz veins. Pyrite, and very rarely secondary copper minerals, occur sporadically in altered rock outside of strongly sheared areas. The overall trend of the belt and of many of the altered areas within the belt are parallel to the regional strike of the layered volcanic rocks. The relationship may indicate the existence of stratabound copper deposits. Those deposits associated with sheared rock may be mobilized derivatives of such stratabound deposits.

Other copper occurrences are scattered throughout the study area and commonly are associated with shears in metavolcanic rocks, rarely in plutonic rock.

\section{Gold Lode Deposits}

Gold-bearing quartz veins are the only known gold lode deposits in the study area. The veins were emplaced on fractures or shear structures in metavolcanic rock and range from a few inches to several feet in width. According to
Livingston and Laney (1920, p. 33-37), the vein material is mostly quartz, but in places contains pyrite, copper, and rarely other sulfide minerals. They consider the gold to be free, and in some deposits, for example those near Black Lake, mostly concentrated in or associated with pyrite that occurs as shoots along the vein. Cook (1954, p. 19) observed that one of the gold-bearing quartz veins is one of a set of otherwise barren veins and differs from them in that it has undergone recurrent fracturing. Little if any alteration is associated with the goldbearing veins. The veins strike northeast and northwest.

\section{Gold Placer Deposits}

Three kinds of placer deposits are found in the study area: (1) residual deposits derived from the weathering of tactite near White Monument (pl. 1), (2) high-level gravels on the pre-Columbia River Basalt Group erosion surface at Dry Diggins and Crooks Corral (pl. 2), and (3) terrace gravels and alluvial deposits along the Snake River.

Some of the high-level gravels are composed mostly of pebbles derived from rocks within the study area, but others contain large quantities of extrinsic pebbles - chiefly quartz, quartzite, and amphibolite - and it is in these deposits that gold has been found. The source of the extrinsic pebbles and the gold is unknown, but it is presumed that both are from the same terrane, presumably east of the study area.

Gold occurs in fine particles in terrace gravels along the Snake River and in alluvium in the present bed of the river. Most of this gold is probably derived from sources upstream, outside of the study area.

\section{Mining Districts and Mineralized Areas}

\section{By Terry J. Close, Francis E. Federspiel, and Andrew M. Leszcykowski, U.S. Bureau of Mines}

This section of the report summarizes a much larger report containing detailed descriptions of all of the many mining properties in the Hells Canyon study area. The larger report, by the same authors, may appear in a different series of publications prepared by the U.S. Bureau of Mines.

\section{Setting}

The Hells Canyon study area includes all or parts of the Crooks Corral, Mountain View, and Seven Devils unorganized mining districts in Idaho, and the Homestead district in Oregon. In this section of the report, the Crooks Corral district is described under the heading of Kirkwood Creek, the Mountain View district under the heading of Jackley Mountain, and the Seven Devils and Homestead districts under the heading of Windy Ridge.

Mining was initially concentrated near Windy Ridge where residual placer claims were staked in the 1870 s. Soon thereafter, 
lode deposits at the Peacock and South Peacock mines were discovered beneath the placer deposits, but the lack of transportation to this remote region prevented their development. Surveying of rail lines to Windy Ridge and along the Snake River in the 1890s stimulated mining activities (Hoyt, 1925), but work on most prospects ceased in 1906 when plans for the railroad were abandoned. Later, a railroad was built to the town of Homestead, Oreg., and this spurred exploration that resulted in the discovery of the Iron Dyke mine. The mine, which is just south of the study area, operated from 1914 until 1928, and is presently (1980) being redeveloped.

After 1928, mining was sporadic around Windy Ridge until the discovery of the Copper Cliff mine in 1965. The mine, about $1 \mathrm{mi}(1.6 \mathrm{~km})$ outside of the study area, is the only active mine in the region. Finding the deposit stimulated exploration for others, resulting in renewed activity at the Red Ledge mine, the Nix group, and the Blue Jacket mine.

Placer mining was attempted at a number of locations along the Snake River but was largely unsuccessful due to small sizes of the deposits and the lack of transportation.

Recorded production from six lode deposits near the study area total about 304,000 tons $(276,000$ t) of ore containing gold, silver, copper, lead, zinc, and tungsten trioxide, worth about $\$ 5$ million at the time of production. Currently, ore is being mined and milled at the Copper Cliff mine at the rate of about 300 tons per day $(270 \mathrm{t} / \mathrm{d})$.

Recorded production from 17 lode deposits within the study area total 55,785 tons $(50,607 \mathrm{t})$. The ore, predominately from tactites near Windy Ridge, contained 9,355 troy oz $(291 \mathrm{~kg})$ gold, 225,530 troy oz $(7,015 \mathrm{~kg})$ silver, 6,109 tons $(5,542 \mathrm{t})$ copper, 1 ton $(0.9 \mathrm{t})$ lead, 40 tons $(36 \mathrm{t}) \mathrm{zinc}$, and $180 \mathrm{lbs}(82 \mathrm{~kg})$ of tungsten trioxide, all worth about $\$ 2$ million. Recorded production from placer deposits along the Snake River is 605 troy oz $(18.8 \mathrm{~kg})$ gold.

Mining claim records for Adams, Idaho, and Nez Perce Counties, Idaho, and Wallowa County, Oreg., show that approximately 4,100 claims have been located within the study area since 1870 . About 1,290 lode and 110 placer claims are in Oregon, and about 2,510 lode and 190 placer claims are in Idaho. Most claims in Oregon are near the mouth of the Imnaha River and along the Snake River. Most claims in Idaho are along two northeast-trending zones; one extends from Sluice Creek to Kirkwood Creek, and the other from Windy Ridge to Rapid River. Within the study area, about 300 unpatented claims are currently held. U.S. Bureau of Land Management records show 186 mining claims covering 3,230 acres $(1,307 \mathrm{~h})$ are patented. There are also many homesteads, some of which have been prospected for placer gold.

Lode deposits in the study area, in order of historic importance, include four main types: (1) contact replacement zones (tactites) containing copper and silver; (2) volcanogenic occurrences bearing copper, silver, zinc, gold, and lead; (3) copperbearing, magnetite-hematite veins and lenses; and (4) siliceous fissure veins and mineralized shear zones containing gold, silver, and copper.
The more important tactite deposits are near Windy Ridge where metal-bearing solutions replaced limestone during intrusion of granodiorite.

Volcanogenic deposits, probably formed during Permian (and Triassic?) marine volcanic activity, occur in and around pyrite-bearing rhyolite intrusions. They are confined to specific strata and are localized by depressions in the ancient topography. These occur as (1) lenses of andesitic and rhyolitic rock and quartz, containing sulfides, (2) sulfide-bearing quartz veins in andesitic rock, and (3) disseminated sulfides in and around stockworks of quartz veinlets in brecciated rhyolite. Lenses and veins occur throughout the study area. The only known disseminated deposits are near Windy Ridge. However, intrusions that may contain disseminated deposits crop out along the Snake River near Caribou, Kirkwood, Willow, Quartz, Rush, Sluice, Oxbow, and Deep Creeks.

Magnetite-hematite veins and lenses are in diorite-gabbro rocks along the Imnaha and Salmon Rivers. These veins also contain pyrite, chalcopyrite, and malachite. They are probably fracture-controlled fissure fillings formed by the circulation of metal-bearing solutions during emplacement of the mafic intrusions.

Fissure veins and mineralized shear zones generally are near contacts with intrusive rocks. Although widely distributed, the most important are near Jackley Mountain.

Tactite deposits were historically the most productive in the study area, but exploration is now focused on volcanogenic occurrences. Tactite deposits still have additional potential, as may the adjacent granodiorite intrusives. Fissure veins and hematite-magnetite veins and lenses received much attention in the past but appear to have little potential.

Most ores were mined from tactite deposits by underground and openpit methods; the ore was usually shipped directly to smelters. Future production is expected to come chiefly from volcanogenic deposits with some production from tactite deposits. The expected output would be mostly copper and its byproducts: gold, silver, zinc, and lead. Deposits in most cases would be mined by underground methods and the core concentrated by flotation and heap leaching. For profitable mining, deposits must have an average recoverable metal content worth more than $\$ 32$ per ton $(\$ 35.30 \mathrm{~m} / \mathrm{t})$, and must be mined and milled at a rate greater than 5,000 tons per day $(4,500 \mathrm{t} / \mathrm{d})$ based on mining costs at the time of this study (1977).

Placer deposits must be minable at a rate of more than 300 cubic yards per day $\left(230 \mathrm{~m}^{3} / \mathrm{d}\right)$ and have recoverable gold valued at more than $\$ 1.20$ per cubic yard $\left(\$ 1.60 / \mathrm{m}^{3}\right)$, based on 1977 mining costs.

\section{Mineralized Areas}

Most mines and prospects are clustered near Windy Ridge, Kirkwood Creek, the Imnaha-Salmon Rivers area, Rapid River, and Jackley Mountain. Another 19 are scattered 
throughout the study area. The locations of these properties are shown on figure 12 .

\section{Windy Ridge}

Windy Ridge, in the south end of the study area (fig. 12), is accessible by dirt road from Council, Idaho. Most lode deposits occur along a northeast-trending belt from the Iron Dyke mine to and beyond the Copper Cliff mine (fig. 12). Most placer claims were on deposits now covered by Hells Canyon Reservoir; others were on residual placers over tactites.

The residual placer deposits were claimed in the 1870 s. They were soon depleted, and development of the underlying tactite copper deposits began in the 1880s. Before 1906, 30,000 tons $(27,200 \mathrm{t})$ of ore containing copper, silver, and gold worth $\$ 1.3$ million at the time of production were produced. Most ore came from the Peacock and South Peacock mines (fig. 12, nos. 84, 85). Production was sporadic after 1906.

Small, high-grade volcanogenic deposits were mined intermittently from the 1890 s until the discovery and development of the Copper Cliff deposit in 1965. The discovery encouraged exploration for similar deposits by nine major mining companies. Work on the Nix claim group and the Red Ledge prospect (fig. 12, nos. 113, 81) resulted in the discovery of mineral resources.

Development of Windy Ridge deposits was hampered by high transportation costs, the inability to make a salable concentrate from the low-grade, complex ores, and the small sizes and irregularities of high-grade deposits. A minimum copper content of 10 percent was required to make mining profitable, so production was limited. Development of new concentration techniques and better transportation have improved the potential for mining.

Most tactite deposits near Windy Ridge are along the north side of a northwest-trending band of limestone inclusions between Landore, Idaho, and the Peacock mine. The deposits consist of malachite- and azurite-coated pods in limestone that is partially to completely replaced by garnet, epidote, specular hematite, magnetite, and quartz. The pods contain bornite, chalcocite, covellite, and minor amounts of pyrite, chalcopyrite, and native copper. Minor amounts of the tungsten minerals, scheelite and powellite, are also present at some prospects. Attempts to market tungsten were largely unsuccessful because of the high molybdenum content of the tungsten minerals.

Tactite deposits at Windy Ridge were mined to shallow depths, but exploratory drilling indicates that they extend below the old workings. Other tactite deposits may be found at depths along the limestone inclusions. Drilling and sampling indicate copper concentrations also occur in adjacent granodiorite. Identified resources total about 2.2 million tons (2 million t) of copper- and silver-bearing tactite.

Volcanogenic occurrences are between the Red Ledge prospect and Antz Creek mine (fig. 12, nos. 81, 116). They are associated with pyrite-bearing rhyolite intrusions; lenses and veins are concentrated near contacts between the intrusive rocks and intercalated andesitic clastic rocks and flows. Disseminated deposits occur mostly in the intrusions.

Lenses of northeast-trending, steeply dipping wallrock contain quartz, pyrite, chalcopyrite, chalcocite, bornite, sphalerite, and minor galena. They are as much as $65 \mathrm{ft}$ (20 m) thick, $380 \mathrm{ft}$ (120 m) long, and $500 \mathrm{ft}(150 \mathrm{~m})$ deep. Volcanogenic veins average less than $2 \mathrm{ft}(0.6 \mathrm{~m})$ thick and usually are less than $200 \mathrm{ft}(60 \mathrm{~m})$ long. They are composed of quartz, calcite, dolomite, and siderite, and lesser amounts of malachite, azurite-coated blebs and streaks of tetrahedrite, and chalcopyrite, bornite, chalcocite, sphalerite, and galena.

Exploratory drilling indicates the presence of extensive disseminated deposits. A deposit at the Red Ledge mine consists of blebs and stringers of pyrite, as well as chalcopyrite, sphalerite, bornite, and chalcocite associated with quartz. Another at the Nix claim group, associated with lenses and vein deposits, consists of disseminated pyrite and copper-bearing sulfides. The volcanogenic resources at Windy Ridge total more than 25 million tons (23 million t) (table 6).

\section{Kirkwood Creek}

Kirkwood Creek, near the middle of the study area (fig. 12), is west by road from Lucile, Idaho. Part of the area is accessible only by boat or trail, and rugged terrain and remoteness from transportation routes inhibited exploration in the past.

Most placer and copper claims were staked by 1915 . The lode claims are along a zone that trends northeast from Sluice Creek to the Blue Jacket mine (fig. 12, no. 33).

Most exploration at the Blue Jacket and Duncan mines (fig. 12, no. 43) was done in anticipation of a railroad being built. The deposits were too small to justify construction of a smelter, and mineralogically too complex to concentrate for shipment to smelters, so when plans for the railroad were abandoned, most mining and exploration ceased. A road built into the region in the 1920s resulted in short-lived activity, and interest was not revived until 1976, when exploratory drilling was begun at the Blue Jacket mine.

The only recorded production from lode deposits in the Kirkwood Creek area is 102 tons (93 t) containing 22 tons (20 t) copper, 1,265 troy oz $(39.3 \mathrm{~kg})$ silver, and 6 troy oz $(0.2 \mathrm{~kg})$ gold, shipped from the Blue Jacket and Duncan mines. About 265 troy oz $(8.2 \mathrm{~kg})$ gold were produced from placer deposits near Kirkwood Creek on the Snake River. An estimated 270 troy oz $(8.4 \mathrm{~kg})$ gold were produced from the elevated placer at Crooks Corral (fig. 12, no. 36).

The principal lode deposits are northeast-trending, volcanogenic lenses and veins. Veins are as thick as $70 \mathrm{ft}(21 \mathrm{~m})$ and can be traced for as much as 4,500 ft $(1,370 \mathrm{~m})$ along strike and $500 \mathrm{ft}(150 \mathrm{~m})$ downdip. The mineralized wallrock contains limonite, malachite, azurite, quartz, barite, native copper, chalcocite, chalcopyrite, pyrite, and sphalerite. 
The volcanogenic deposits have gold-, silver-, and copper-bearing resources of about 2 million tons (1.8 million $\mathrm{t}$ ) (table 6).

Less important mineral deposits near Kirkwood Creek consist of zones near contacts between metavolcanic and basic intrusive rocks. These contain sulfide-bearing quartz veins or lenses that are less than $2 \mathrm{ft}(0.6 \mathrm{~m})$ thick. One contains gold-, silver-, and copper-bearing resources totaling 25,600 tons $(23,200 \mathrm{t})$.

\section{Imnaha-Salmon Rivers}

The Imnaha-Salmon Rivers area is in the northern part of the study area (fig. 12) near the mouths of the Imnaha and Salmon Rivers. Access is by jet boat from Lewiston, Idaho, or by jeep and foot trails from Imnaha, Oreg.

Most of the mineralized zones were discovered and explored by 1915 . Development ceased when a steamboat sank with the equipment for a stampmill.

Also, the operators recognized that the small, low-grade deposits could not be mined profitably. The only recorded production was 2 tons $(1.8 \mathrm{t})$ of ore containing 3 troy oz (93 g) gold shipped from the Pullman mine (fig. 12, no. 11).

The principal deposits - copper-bearing magnetite-hematite veins and lenses - are along shear zones in metamorphosed gabbro and diorite; some zones are as much as $10 \mathrm{ft}$ ( $3 \mathrm{~m})$ thick and $600 \mathrm{ft}(180 \mathrm{~m})$ long. The zones containing the most consistent metal values are northeast trending and steeply dipping. Other deposits include silver- and copper-bearing volcanogenic veins and lenses in rhyolitic to andesitic volcanic rocks and a copper-bearing tactite in limestone.

The area has copper resources totaling 304,660 tons $(276,390 \mathrm{t})$ of which 302,500 tons $(274,400 \mathrm{t})$ are in magnetite-hematite veins and lenses and 2,160 tons (1,960 t) are in volcanogenic deposits (table 6).

Further study would probably disclose additional resources, but this is unlikely to be carried out in the near future since with present technology, copper cannot be recovered economically from the magnetite-hematite gangue, and iron is not recoverable because of the small size of the deposits. The volcanogenic deposits are too remote, small, and low grade to be of economic interest.

\section{Rapid River}

Mines and prospects in the Rapid River area are near the mouth of West Fork Rapid River, in the southeastern part of the study area (fig. 12). They are south by road and trail from Riggins, Idaho.

Most lode-deposit claims were discovered and claimed by 1900 . Most placer claims were on limestone along Rapid River. No mineral production has been recorded.

Mineral occurrences consist of a tactite, volcanogenic lenses, and mineralized shear zones. Mineralized zones are as much as $14 \mathrm{ft}(4.3 \mathrm{~m})$ thick, $500 \mathrm{ft}(150 \mathrm{~m})$ long, and have gold- and copper-bearing resources totaling 149,750 tons $(135,850 \mathrm{t})$ (table 6). Additional resources may exist; however, they are probably small and scattered.

\section{Jackley Mountain}

Jackley Mountain, in the southeastern part of the study area (fig. 12), is near the headwaters of West Fork and Lake Fork Rapid River, and Granite, Copper, and Paradise Creeks. It is north by road from Bear, Idaho.

Gold-bearing quartz fissure veins were prospected and most of them were claimed by 1910 . They are along a zone that trends northeast from Black Lake to Oxbow Creek. The town of Iron Springs was settled in 1903; however, by 1920 , the town and mineral prospects were abandoned because of high mining costs caused by short working seasons and poor transportation. The Summit, Bald Eagle, and Maid of Erin mines (fig. 12, nos. 77, 62, and 76) produced 14,457 tons $(13,115 \mathrm{t})$ of ore containing 7,196 troy oz $(224 \mathrm{~kg})$ gold and 1,491 troy oz $(46 \mathrm{~kg})$ silver.

Veins at Jackley Mountain are as much as $18 \mathrm{ft}$ (5.5 m) thick; most trend northeast and dip steeply along shear zones in metamorphosed volcanic rock intruded by diorite. Composed mainly of quartz, the veins locally contain pods and disseminations of pyrite and chalcopyrite. Sulfides are concentrated in narrow veins or where wider veins pinch out. Free-milling gold ore occurs in shallow oxide deposits over sulfide pods. When sulfides were encountered, lower grades and the lack of suitable milling equipment made mining uneconomical.

Veins near Jackley Mountain contain gold-, silver-, and copper-bearing resources totaling about 372,050 tons $(337,520 \mathrm{t})$ (table 6). Additional deposits are probably present (fig. 12); however, mining and milling costs would be high, although a central custom mill would reduce unit costs.

\section{Miscellaneous Properties}

Eighteen lodes are outside of the principal mineralized areas. Two, the Battle Creek and the Yellowboy (fig. 12, nos. 79 and 2), have recorded production. The Yellowboy produced 340 tons $(308 \mathrm{t})$ of ore, from which 91 troy oz $(2.8 \mathrm{~kg})$ of gold and 161 troy oz $(5 \mathrm{~kg})$ of silver were recovered. The Battle Creek produced 81 troy oz $(2.5 \mathrm{~kg})$ of gold.

Two lode deposits have resources. The Old Timer vein prospect (fig. 12, no. 46), contains a submarginal resource estimated at 1,400 tons (1,300 t), and the Treasure group (fig. 12, no. 5), a volcanogenic occurrence, has a submarginal resource of 2,400 tons $(2,200 \mathrm{t}$ ) (table 6).

\section{Placer Deposits}

Placer gold production along the Snake River came mainly from small channel deposits. Large-scale dredging was not profitable because of the limited extent of deposits, 


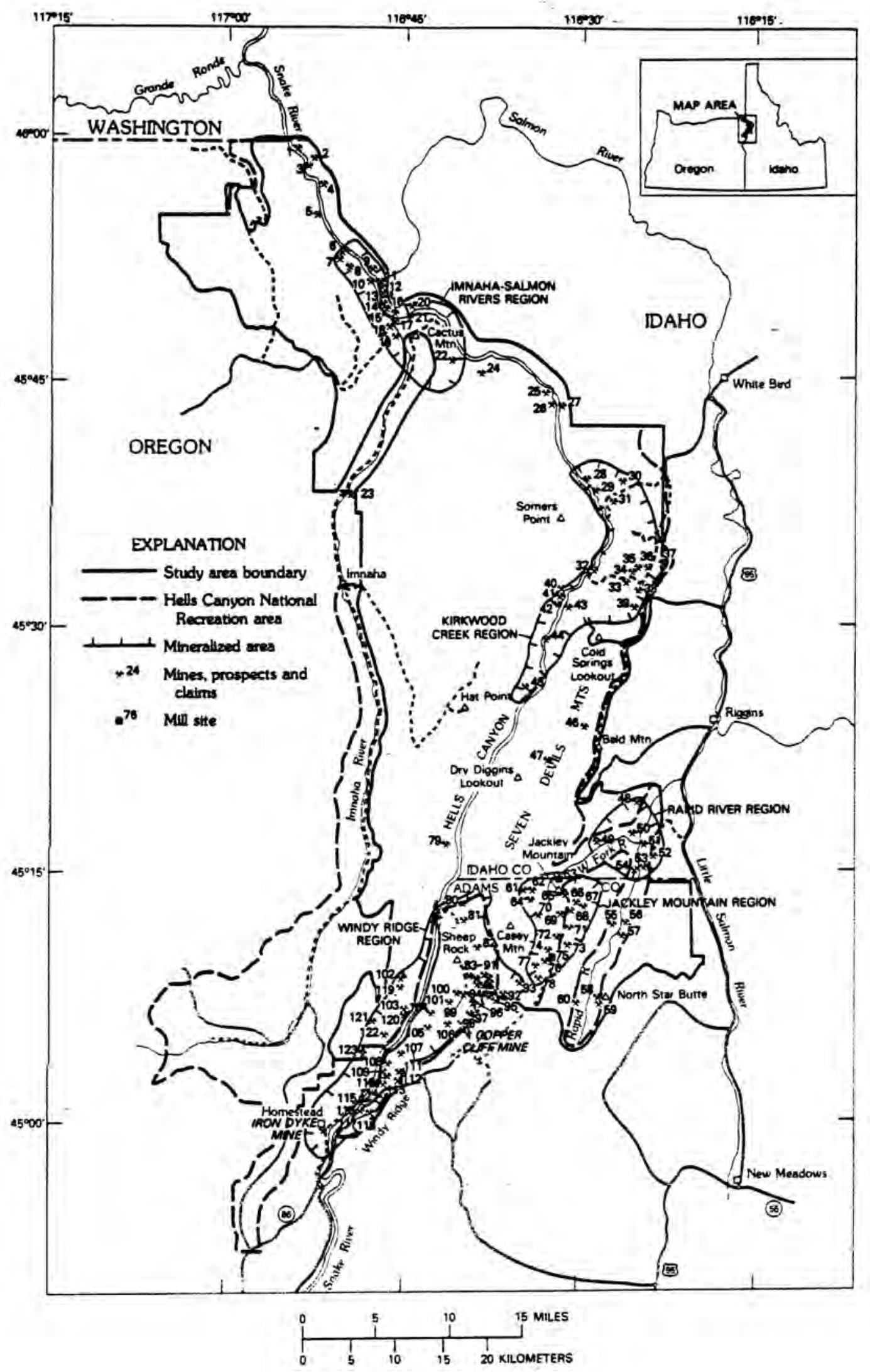

Figure 12 (and facing page). Mines, prospects, and mineralized areas in the Hells Canyon study area. 
[Mines and prospects having resources or resource potential are underlined]

\begin{tabular}{|c|c|c|c|}
\hline 1. & $\underline{\text { Cache Creek Rapids adit }}$ & 63. & Rankin mill \\
\hline 2. & Yellowboy mine & 64. & Stevens Saddle prospect \\
\hline 3. & Little Cougar Creek adit & 65. & Jackley Ridge prospect \\
\hline 4. & $\underline{\text { Cottonwood Creek adit }}$ & 66. & Mayflower group \\
\hline 5. & Treasure group & 67. & White Rose prospect \\
\hline 6. & Cherry Creek prospect & 68. & $\underline{\text { Holbrook Saddle prospect }}$ \\
\hline 7. & $\underline{\text { Greenhorn and Verdie lodes }}$ & 69. & $\underline{\text { Middle Mountain prospect }}$ \\
\hline 8. & $\underline{\text { Papico lode }}$ & 70. & Monument Peak prospect \\
\hline 9. & First Creek adit & 71. & Iron Springs prospect \\
\hline 10. & $\underline{\text { Salmon Bar adit }}$ & 72. & Pactolian Gulch prospect \\
\hline 11. & Pullman mine & 73. & Curren Mount prospect \\
\hline 12. & Pullman Gulch prospect & 74. & $\underline{\text { Satan Lake prospect }}$ \\
\hline 13. & Lower Sheep Rapids shaft & 75 . & High Five placer; Maid of Erin and Summit millsites \\
\hline 14. & Mountain Sheep prospect & 76. & Maid of Erin mine \\
\hline 15. & Bear Rapids adit & 77. & $\underline{\text { Summit mine }}$ \\
\hline 16. & Imnaha Rapids prospect & 78. & Rock Lake prospect \\
\hline 17. & $\underline{\text { Fargo group }}$ & 79. & Battle Creek mine \\
\hline 18. & Banner group & 80. & $\underline{\text { Cliff prospect }}$ \\
\hline 19. & Highland Mary and Western Union groups & 81. & $\underline{\text { Red Ledge prospect }}$ \\
\hline 20. & Divide Creek prospect & 82. & Heady prospect \\
\hline 21. & Divide Creek Rapids prospect & 83. & Haily Ridge prospect \\
\hline 22. & Dug Creek prospect & 84. & Peacock mine \\
\hline 23. & Blue Bucket prospect & 85. & $\underline{\text { South Peacock mine }}$ \\
\hline 24. & Deep Creek adits & 86. & $\underline{\text { Panama Pacific (Victoria) claims }}$ \\
\hline 25. & Copper Mountain prospect & 87. & Lower Devil's Hollow prospect \\
\hline 26. & Electrolytic group & 88. & $\underline{\text { Ritchie-Gulch prospect }}$ \\
\hline 27. & Highrange prospect & 89. & Devils's Hollow prospect \\
\hline 28. & $\underline{\text { Davis Rapids adit }}$ & 90. & Ritchie Gulch adit \\
\hline 29. & Copper Queen prospect & 91. & Pepper box No. 2 claim \\
\hline 30. & Short Branch claims & 92. & Virginus claim \\
\hline 31. & Pittsburg Landing prospect & 93. & Victory Tungsten mine \\
\hline 32. & Blakely prospect & 94. & Chieftain claim \\
\hline 33. & Blue Jacket mine & 95. & California group \\
\hline 34. & $\underline{\text { Kirby Creek prospect }}$ & 96. & Emily group \\
\hline 35. & Sadie prospect & 97. & White Monument Copper mine \\
\hline 36. & Crooks Corral elevated placer & 98. & Lockwood mine \\
\hline 37. & Virginia group & 99. & Tussel mine \\
\hline 38. & Cow Camp prospect & 100. & $\underline{\text { Tussel adit }}$ \\
\hline 39. & Wickiup Butte prospect & 101. & $\underline{\text { Tussel shaft }}$ \\
\hline 40. & Hominy Creek placer & 102. & Brooklyn-Allen group \\
\hline 41. & Iron King group & 103. & Dove Creek prospect \\
\hline 42. & Temperance placer & 104. & Dry Gulch prospect \\
\hline 43. & Duncan mine & 105. & Allison Creek prospect \\
\hline 44. & High Bar adit & 106. & East Allison Gulch prospect \\
\hline 45. & $\underline{\text { Hat Point prospect }}$ & 107. & Nibble Gulch prospect \\
\hline 46. & Old Timer prospect & 108. & North Lime Peak prospect \\
\hline 47. & Dry Diggins elevated placer & 109. & $\underline{\text { Lime Peak mine }}$ \\
\hline 48. & Blue Gulch prospect & 110. & Golden Star claim \\
\hline 49. & $\underline{\text { McCrea Creek prospect }}$ & 111. & $\underline{\text { Paducah group }}$ \\
\hline 50. & Oregon group & 112. & Eureka group \\
\hline 51. & Cora Gulch prospect & 113. & Nix group \\
\hline 52. & Rattlesnake Ridge prospect & 114. & Crackerjack mine \\
\hline 53. & Cougar Creek prospect & 115. & $\underline{\text { Crackerjack mine }}$ \\
\hline 54. & Wyant Creek prospect & 116. & $\overline{\text { Antz Creek mine }}$ \\
\hline 55. & Paradise Cabin prospect & 117. & Azurite mine \\
\hline 56. & Trail Creek prospect & 118. & $\overline{\text { Terry group }}$ \\
\hline 57. & Black Leopard prospect & 119. & $\underline{\text { Sunshine group }}$ \\
\hline 58. & North Star Butte prospect & 120. & Olympia group \\
\hline 59. & Indian Springs prospect & 121. & Argenta group \\
\hline 60. & Twin Lakes prospect & 122. & Lime Point prospect \\
\hline 61. & Anchor Creek prospect & 123. & Nelson Ridge prospect \\
\hline 62. & $\underline{\text { Bald Eagle mine }}$ & & \\
\hline
\end{tabular}


Table 6. Estimates of gold, silver, and copper resources in lode deposits in the Hells Canyon study area

[Leaders (-), insignificant amounts. Metric conversions: tons x $0.9072=$ metric tons; ounce per ton x $34.285=$ grams per metric ton]

\begin{tabular}{|c|c|c|c|c|c|c|}
\hline \multirow[t]{2}{*}{ Name } & \multirow[t]{2}{*}{ Type of occurrence } & \multirow{2}{*}{$\begin{array}{c}\text { Resource } \\
\text { classification'1 }\end{array}$} & \multirow{2}{*}{$\begin{array}{c}\text { Resource } \\
\text { estimate } \\
\text { (tons) }\end{array}$} & \multicolumn{3}{|c|}{ Metal content } \\
\hline & & & & Gold & Silver & Copper \\
\hline \multicolumn{7}{|c|}{ Windy Ridge } \\
\hline Allison Creek prospect & Volcanogenic lens & Submarginal & 12,620 & - & - & 0.72 \\
\hline \multirow[t]{2}{*}{ Brooklyn-Allen group } & Tactite & do & 750 & & & 1.7 \\
\hline & Volcanogenic lens & do & 30,420 & - & - & 1.1 \\
\hline Cliff prospect & Volcanogenic vein & Paramarginal & 20,800 & 0.3 & 1.9 & 2.2 \\
\hline Crackerjack mine & do & do & 3,600 & & 7.2 & 1.4 \\
\hline Dry Gulch prospect & Volcanogenic lens & Submarginal & 830 & & & .67 \\
\hline Eureka group & do & do & 96,000 & - & .32 & .9 \\
\hline Golden Star claim & do & Paramarginal & 600 & & & 1.6 \\
\hline Lime Peak mine & do & Submarginal & 4,150 & - & 0.15 & 1.4 \\
\hline $\begin{array}{l}\text { Lower Devil's Hollow } \\
\text { prospect. }\end{array}$ & Fissure vein & do & 1,140 & - & - & 1.2 \\
\hline Nix claim group & $\begin{array}{l}\text { Volcanogenic lens } \\
\text { and vein }\end{array}$ & do & 45,600 & 0.03 & .2 & 0.4 \\
\hline Peacock mine & Tactite & Paramarginal & 450,000 & - & .7 & 1.35 \\
\hline Pepperbox no. 2 claim & do & Submarginal & 650 & - & - & .35 \\
\hline Red Ledge prospect ${ }^{2}$ & $\begin{array}{l}\text { Volcanogenic lens } \\
\text { and disseminated } \\
\text { sulfides }\end{array}$ & Paramarginal & $25,298,000$ & .02 & 1.21 & .51 \\
\hline River Queen mine & Volcanogenic lens & do & 7,100 & - & - & 1.7 \\
\hline \multirow[t]{2}{*}{ South Peacock mine } & Tactite & do & $\underline{1,700,000}$ & - & .56 & 1.59 \\
\hline & & Subtotal & $27 \overline{6,662,260}$ & & & \\
\hline \multicolumn{7}{|c|}{ Kirkwood Creek } \\
\hline Blakely prospect & Fissure vein & Paramarginal & 25,600 & 0.12 & 0.2 & 0.93 \\
\hline Blue Jacket mine ${ }^{3}$ & Volcanogenic lens & do & $1,900,000$ & .035 & 3.5 & 4.0 \\
\hline Copper Queen prospect & do & Submarginal & 5,600 & - & .2 & .4 \\
\hline Davis Rapids adit & do & do & 1,400 & - & - & .4 \\
\hline Hat Point prospect & do & do & 52,500 & - & - & 1.1 \\
\hline \multirow[t]{2}{*}{ Virginia group } & do & do & $\underline{84,000}$ & .04 & .22 & .22 \\
\hline & & Subtotal & $2,069,100$ & & & \\
\hline \multicolumn{7}{|c|}{ Imnaha-Salmon Rivers } \\
\hline Fargo group 4 & $\begin{array}{l}\text { Magnetite hematite } \\
\text { veins and lenses. }\end{array}$ & Submarginal & 293,200 & - & - & .48 \\
\hline $\begin{array}{l}\text { Greenhorn and Verdie } \\
\text { lodes. }\end{array}$ & Volcanogenic vein & do & 560 & - & 1.7 & 1.1 \\
\hline Imnaha Rapids prospect & $\begin{array}{l}\text { Magnetite-hematite } \\
\text { vein and lens. }\end{array}$ & do & 9,300 & - & - & 6 \\
\hline \multirow[t]{2}{*}{ Salmon Bar adit } & Volcanogenic lens & do & $\underline{1,600}$ & - & - & 1.3 \\
\hline & & Subtotal & 304,660 & & & \\
\hline
\end{tabular}


Table 6. Estimates of gold, silver, and copper resources in lode deposits in the Hells Canyon study areaContinued.

[Leaders (—), insignificant amounts. Metric conversions: tons x $0.9072=$ metric tons; ounce per ton x $34.285=$ grams per metric ton]

\begin{tabular}{|c|c|c|c|c|c|c|}
\hline \multirow[t]{2}{*}{ Name } & \multirow[t]{2}{*}{ Type of occurrence } & \multirow{2}{*}{$\begin{array}{c}\text { Resource } \\
\text { classification } 1\end{array}$} & \multirow{2}{*}{$\begin{array}{c}\text { Resource } \\
\text { estimate } \\
\text { (tons) }\end{array}$} & \multicolumn{3}{|c|}{ Metal content } \\
\hline & & & & Gold & Silver & Copper \\
\hline \multicolumn{7}{|c|}{ Rapid River } \\
\hline Cora Gulch prospect & Shear zone & Submarginal & 1,550 & 0.08 & - & 0.28 \\
\hline McCrea Creek prospect & Volcanogenic lens & do & 2,400 & - & - & 1.5 \\
\hline \multirow[t]{2}{*}{ Oregon group } & Tactite & do & $\underline{145,800}$ & .01 & - & .15 \\
\hline & & Subtotal & 149,750 & & & \\
\hline \multicolumn{7}{|c|}{ Jackley Mountain } \\
\hline Bald Eagle Mine ${ }^{5}$ & Vein & Submarginal & 18,750 & 0.03 & 0.4 & 0.05 \\
\hline $\begin{array}{l}\text { Curren Mountain } \\
\text { prospect. }\end{array}$ & do & do & 25,300 & .03 & .3 & - \\
\hline Maid of Erin mine & do & Paramarginal & 245,000 & .12 & .1 & - \\
\hline \multirow[t]{2}{*}{ Summit mine } & do & do & $\underline{83,000}$ & .12 & .1 & - \\
\hline & & Subtotal & 372,050 & & & \\
\hline \multicolumn{7}{|c|}{ Miscellaneous prospects } \\
\hline Old Timer prospect & Vein & Submarginal & 1,400 & - & - & 0.53 \\
\hline \multirow[t]{3}{*}{ Treasure group } & Volcanogenic lens & do & $\underline{2,400}$ & 0.006 & 0.27 & .34 \\
\hline & & Subtotal & 3,800 & & & \\
\hline & & TOTAL & $30,561,620$ & & & \\
\hline
\end{tabular}

${ }^{1}$ Resources classified according to definitions adopted by the U.S. Bureau of Mines and the U.S. Geological Survey (1976).

${ }^{2}$ Also averages 1.32 percent zinc.

${ }^{3}$ From company data.

${ }^{4}$ Also averages 34.6 percent iron.

${ }^{5}$ Also averages 0.01 percent zinc. 
and because the small size of gold particles made recovery difficult. Recorded placer gold production totals 605 troy oz $(18.8 \mathrm{~kg})$.

Placer deposits occur both in the riverbed and in terraces above the present channel. In places they are covered by as much as $70 \mathrm{ft}(21 \mathrm{~m})$ of overburden. Gold and black sand occur in highest concentrations in skim bars—small, lens-shaped, irregular concentrations mainly along the present stream channel.

The riverbed of the Snake River contains about 300 million cubic yards ( 230 million $\mathrm{m}^{3}$ ) of alluvium. Samples contained as much as $\$ 8.90$ gold per cubic yard $\left(\$ 11.60 / \mathrm{m}^{3}\right)$, but averaged less than 10 cents per cubic yard $\left(13\right.$ cents $\left./ \mathrm{m}^{3}\right)$ at a gold price of $\$ 150$ per troy ounce $(\$ 4.82 / \mathrm{g})$. Skim bar deposits may be minable by small-scale selective methods.

The estimated volume of river gravel in river terraces is 70 million cubic yards $\left(54\right.$ million $\left.\mathrm{m}^{3}\right)$. Samples contained as much as 64 cents gold per cubic yard $\left(84\right.$ cents $\left./ \mathrm{m}^{3}\right)$, but averaged 2 cents per cubic yard $\left(3\right.$ cents $\left./ \mathrm{m}^{3}\right)$. Samples indicate that the terraces contain small, low-grade placers that are not minable.

The Rapid River shows little evidence of placer mining; production, if any, has not been recorded. The river and its tributaries contain about 9 million cubic yards $\left(7\right.$ million $\left.\mathrm{m}^{3}\right)$ of alluvium. Sample data indicate no gold concentrations. The Snake River and Rapid River alluvial gravel deposits are too remote from potential markets to be classified as resources of sand and gravel.

Elevated placer deposits were worked at Crooks Corral and Dry Diggins (fig. 12, nos. 36 and 47). These are small and far from adequate water supplies. The placer at Crooks Corral is nearly mined out; the remaining gravel averages 9 cents gold per cubic yard $\left(12\right.$ cents $\left./ \mathrm{m}^{3}\right)$. The Dry Diggins elevated placer has 627,000 cubic yards $\left(479,000 \mathrm{~m}^{3}\right)$ of gravel averaging about $\$ 3.00$ gold per cubic yard $\left(\$ 3.90 / \mathrm{m}^{3}\right)$; it would be minable if water could be economically supplied.

\section{Assessment of Mineral Resource Potential}

Thirty-four lode deposits have resources (table 6) totaling about 31 million tons ( 28 million $\mathrm{t}$ ) of which about 25 million tons (23 million t) are at the Red Ledge prospect (fig. 12, no. 81). Another 37 lode deposits may have mineral resources but are not sufficiently exposed to permit estimates (fig. 12).

The mineral resource potential of different parts of the Hells Canyon study area is here classified as high, moderate, or low, following the definitions adopted by the U.S. Geological Survey (Taylor and Steven, 1983; Goudarzi, 1984, p. 7). A little more than $42 \mathrm{mi}^{2}\left(109 \mathrm{~km}^{2}\right)$ in 21 separate areas have medium and high mineral resource potential. These areas, about 4 percent of the study area, are interspersed in larger areas of low mineral resource potential and are concentrated in the southern part of the study area. The locations of the areas of high and medium potential are shown on figure 1 .

The category to which an area is assigned was determined by a synthesis of geologic, geochemical, and geophysical information (by the U.S. Geological Survey) in conjunction with data gathered during investigations of mining properties (by the U.S. Bureau of Mines). Areas considered most likely to contain mineral resources are those for which favorable evidence is provided from several fields of investigation.

Most of the land assigned a low mineral resource potential is overlain by hundreds to thousands of feet of basalt flows of the Columbia River Basalt Group. Although low anomalous values of metals were found in the basalt, these simply reflect normal chemical variation; the basalt has no indication of mineralization nor are metallic mineral deposits anywhere known in it. It is possible or even likely that ore deposits exist beneath the basalt, but exploration would be difficult, and for mining to be feasible, it would be necessary to discover a rich ore body. With the exception of one small area where an ore body may underlie a thin cover of basalt, the entire area blanketed by the Columbia River Basalt Group has a low potential for the discovery of mineral resources.

The types of ore bodies that may exist in the study area are volcanogenic deposits, tactite deposits, vein deposits, porphyry deposits, and placer deposits. The metals included in these deposits are gold, silver, copper, molybdenum, lead, tungsten, and zinc. The localities of the areas having high and moderate potentials for mineral resources are shown on figure 1. Most of the areas assigned high and moderate potentials are those that may have volcanogenic deposits containing silver, copper, molybdenum, lead, and zinc; because of the common association of these five metals, they are considered as a unit.

\section{Silver, Copper, Molybdenum, Lead, and Zinc}

\section{Area 1}

Area 1 (fig. 1) occupies $4 \mathrm{mi}^{2}\left(10 \mathrm{~km}^{2}\right)$ at the south extremity of the study area, on the east side of Hells Canyon Reservoir and the west slopes of Windy Ridge. The area is underlain by metabasalt, meta-andesite, and some interlayered clastic rocks and limestone, all part of the Seven Devils Group, and at one place by a sliver of limestone that may be part of the Seven Devils Group or the Martin Bridge Limestone. The rocks are locally altered, silicified, and stained by limonite, and at a few places by malachite. The northern part of the area is astride a major northeast-trending fault, which may have been a conduit for mineralizing solutions, and malachite occurs along the fault and nearby fractures.

A linear magnetic high coincides with Windy Ridge (pl. 1) and its northeast extension, and may indicate the subsurface extension of the granodiorite pluton near White Monument (pl. 1). In that area, mineralizing solutions associated with the pluton resulted in a number of contact ore bodies, and such deposits may exist at depth in area 1, although the 
andesite and basalt at the surface would be a more likely host for volcanogenic deposits.

Eighteen geochemical samples from this area contain anomalous amounts of one or more of the five metals. The samples include 3 stream-sediment samples and 15 rock samples; of the latter, 12 are of metavolcanic rocks, 1 is of limestone, 1 is of shale, and 1 is of rhyolite from a dike. All three stream-sediment samples contain anomalous amounts of silver and zinc, and one contains lead. Of the rock samples, 9 contain anomalous amounts of silver; 7, copper; 4, molybdenum; and 4, lead. Three rock samples (HA 0381, HA 0383, and HG 1269 ) contain large amounts of silver ( 30 to $150 \mathrm{ppm}$ ), and the same three samples and a fourth one (HG 1272) contain large amounts of copper (7,000 to more than 20,000 ppm).

Mining properties include the North Lime Peak prospect, Lime Creek mine, Golden Star claim, Paducah group, Eureka group, Nix group, Crackerjack mine, River Queen mine, Antz Creek mine, and Azurite mine. The Lime Peak mine, Eureka group, and Nix group contain 145,750 tons (32,220 t) of submarginal copper, silver, and gold resources, and the Golden Star claim, Crackerjack mine, and River Queen mine contain 11,300 tons $(10,250 \mathrm{t})$ of paramarginal copper and silver resources.

Area 1 has a moderate potential for copper and silver resources in volcanogenic deposits. This assessment is based on local alteration, silicification, and mineralization, the possibly favorable effect by solutions from a nearby granitic pluton whose presence is indicated by geomagnetic evidence, the presence of geochemical anomalies, and the existence of known resources.

\section{Area 2}

Area 2 (fig. 1) occupies $1.5 \mathrm{mi}^{2}\left(3.9 \mathrm{~km}^{2}\right)$ on the east side of Hells Canyon Reservoir between Kinney and Allison Creeks. The area is underlain by metabasalt and meta-andesite of the Seven Devils Group that are locally intruded by dikes of diorite. A major northeast-trending fault passes through the northwest corner of the area, and this fault may have been a conduit for mineralizing solutions.

A linear magnetic high coinciding with the northeast extension of Windy Ridge (pl. 1) may indicate the subsurface extension of the granodiorite pluton near White Monument (pl. 1) at the east side of area 2. Near White Monument, mineralizing solutions associated with the pluton deposited a number of contact ore bodies; such deposits may exist in area 2 , although the basalt and andesite at the surface would be a more likely host for volcanogenic deposits.

Five geochemical samples contain anomalous amounts of one or more of the five metals. The samples include 1 soil and 4 rock samples; of the latter, 2 are of metavolcanic rocks and 2 are of diorite from dikes. The soil sample contains an anomalous amount of zinc. Two of the rock samples contain anomalous amounts of silver; 2, zinc; 1, copper; 1, molybdenum; and 1, lead. The values of the anomalies are low except in sample HS 0898 that contains 2,000 ppm molybdenum.

Mining properties include the Dry Gulch prospect, which contains 830 tons (750 t) of paramarginal copper resources, and the Allison Creek prospect, which contains 2,620 tons $(2,380 \mathrm{t})$ of submarginal copper resources.

Area 2 has a moderate potential for a copper resource in volcanogenic deposits on the basis of local mineralization, the possibly favorable effect by solutions from a nearby granitic pluton whose presence is indicated by geomagnetic evidence, the presence of geochemical anomalies, and the existence of known resources.

\section{Area 3}

Area 3 (fig. 1) occupies $3.5 \mathrm{mi}^{2}\left(9.1 \mathrm{~km}^{2}\right)$ in an irregularly shaped area extending from near Lockwood Saddle around the west, north, and east sides of White Monument to near Pepperbox Hill; the parts of area 3 that are southeast of Lockwood Saddle and south of Pepperbox Hill are outside of the study area. The area includes granitic rocks and metavolcanic rocks of the Seven Devils Group along the contact zone around the pluton at White Monument, the granitic rocks in the north part of the pluton, and inclusions of limestone in the granitic pluton. The inclusions have been partly converted into tactite.

A magnetic high is associated with the granitic pluton near White Monument (pl. 1), but the shape of area 3 does not coincide in detail with the outline of the magnetic anomaly.

Eight geochemical samples contain anomalous amounts of the five metals and of tungsten. The samples include 1 stream-sediment sample containing an anomalous amount of lead, and 7 rock samples: 1 is of granite; 2 are of diorite; 2 are of tactite; and 2 are of highly mineralized tactite. Of the rock samples, 5 contain anomalous amounts of copper, and 4 are highly anomalous (15,000-20,000 ppm); 4 contain anomalous amounts of silver, and 3 are highly anomalous (150-500 ppm); 4 contain anomalous amounts of molybdenum, and 3 are highly anomalous (150-2,000 ppm); 1 contains an anomalous amount of lead; 1 contains an anomalous amount of zinc; and 3 contain anomalous amounts of tungsten. Two of the latter are highly anomalous (500 ppm).

In addition, three stream-sediment samples collected downstream from area 3 along Copper Creek indicate copper and silver mineralization within the area (HA 0332, HS 0858, HS 0859).

Mining properties include the Peacock mine, South Peacock mine, Panama Pacific (Victoria) claims, Lower Devils Hollow prospect, Richie Gulch prospect, Devils Hollow prospect, and Pepperbox No. 2 claim. The Peacock mine and the South Peacock mine contain 2,150,000 tons $(1,950,000 \mathrm{t})$ of paramarginal copper-silver resources, and the Lower Devils Hollow prospect and the Pepperbox No. 2 claim contain 1,790 tons $(1,624 \mathrm{t})$ of submarginal copper resources.

Area 3 has a high potential for copper and silver resources in tactite deposits, and a moderate potential for copper resources in volcanogenic and porphyry deposits. This 
assessment is based on the widespread mineralization and geochemical anomalies in and around the granitic pluton, the area's past production record, and its known resources.

\section{Area 4}

Area 4 (fig. 1) occupies $2.5 \mathrm{mi}^{2}\left(6.5 \mathrm{~km}^{2}\right)$ east of the Rapid River, chiefly in the drainage of the unnamed south fork of Fry Pan Creek. The area is underlain by a variety of schists with some gneiss and migmatite. The schists are chiefly composed of muscovite, quartz, chlorite, and graphite, but some contain biotite and amphibole. A north-trending thrust fault bisects the area, separating a plate composed mostly of schist to the west from a plate composed mostly of gneiss to the east.

Area 4 coincides with the east side of a magnetic low shaped like an isosceles triangle with its apex to the south (U.S. Geological Survey, 1980, south-central part of map). The significance of the magnetic anomaly is unknown; a trough in the magnetic low extends across the trend of the thrust fault and other thrust faults to the west, suggesting that the entire magnetic low may be related to rocks beneath the thrust faults.

Nineteen geochemical samples contain anomalous amounts of silver, molybdenum, lead, and zinc. The samples include 9 stream-sediment samples and 10 rock samples, and all anomalous values are low. Four samples contain anomalous amounts of silver; 1 is molybdenum; 4 are lead; and 13 are zinc.

No mining properties were found in area 4.

Despite the lack of highly mineralized rocks and past prospecting, the inability to relate magnetic data to geologic features, and the low values of metallic anomalies, area 4 has a moderate potential for a zinc resource. A high percentage of the samples collected in this area contain anomalous amounts of metals, and their abundance and concentration suggest a large, if concealed, source of mineralized rock.

\section{Area 5}

Area 5 (fig. 1) occupies $1 \mathrm{mi}^{2}\left(2.6 \mathrm{~km}^{2}\right)$ at Black Point and at the intersection of Grassy Ridge and Haley Ridge (pl. 1). The area is underlain by metabasalt and meta-andesite of the Seven Devils Group. These volcanic rocks have the same northward trend as the volcanic rocks of the Seven Devils Group in the extensively mineralized Red Ledge area (area 8) $2 \mathrm{mi}(3 \mathrm{~km})$ to the north, and may in part be the same rocks. Also, a major north-northeast-trending fault, which is locally mineralized, passes through the area near Black Point.

A magnetic low (U.S. Geological Survey, 1980, southwest part of map) forms a northeast-trending trough near area 5 , and this area is in and on the west side of the trough where the trough plunges abruptly toward magnetic lows in the Red Ledge area. The magnetic lows in the Red Ledge area (pl. 1) are associated with hydrothermal alteration and silicification. The configuration of the magnetic intensity contour lines suggest that rocks underlying area 5 may be at the fringe of the area affected by these processes in the Red Ledge area.
Seven geochemical samples contain anomalous amounts of silver, copper, or lead. The samples include 1 soil sample and 6 rock samples, all metavolcanic rocks of the Seven Devils Group. Five samples contain anomalous amounts of silver; 1 of copper; and 1 of lead. All anomalous values are low.

No mining properties were found in area 5.

Area 5 has a moderate potential for a silver resource in volcanogenic deposits because of its possible stratigraphic and structural continuity with the volcanogenic deposit in the Red Ledge area (area 8). The possibility of hydrothermal alteration is suggested by the configuration of the magnetic intensity contour lines, and by the geochemical anomalies.

\section{Area 6}

Area 6 (fig. 1) occupies $0.5 \mathrm{mi}^{2}\left(1.3 \mathrm{~km}^{2}\right)$ on the north side of Deep Creek and on the southeast side of Emmett Mountain. The area is underlain by metavolcanic rocks of the Seven Devils Group, and is elongate parallel to and near the west side of a pluton of diorite.

Area 6 does not coincide with any magnetic anomaly. It is on a slope of magnetic relief that dips northwest from the diorite pluton toward the Red Ledge area (area 8).

Eleven geochemical samples contain anomalous amounts of silver, copper, lead, or zinc. The samples include 1 streamsediment sample, 1 soil sample, and 9 rock samples. Of the rock samples, 1 is of rhyolite; 1 is of metabasalt; 3 are of meta-andesite; and 4 are altered to such an extent that it could not be determined whether they are andesite or basalt. Most of the samples contain sparse, disseminated pyrite, and two are silicified. Two samples contain anomalous amounts of silver; 2, copper; 6, lead; and 5, zinc. With the exception of one copper value of 1,500 ppm in one of the altered volcanic rocks, all anomalous values are low.

No mining properties were found in area 6 .

The high percentage and concentration of samples containing anomalous amounts of metals suggest the possibility of an ore body, so area 6 is classified as having a moderate potential for a volcanogenic deposit containing resources of lead and zinc.

\section{Area 7}

Area 7 (fig. 1) occupies $3.5 \mathrm{mi}^{2}\left(9.1 \mathrm{~km}^{2}\right)$ in an irregularly shaped area extending from the headwaters of Granite Creek to the headwaters of the Lake Fork of the Rapid River and Pactolian Gulch (pl. 1). The area is underlain by metavolcanic rocks of the Seven Devils Group and by tabular, northeasttrending plutons that were intruded into the Seven Devils Group and range in composition from diorite to granite. Some of the metavolcanic rocks adjacent to the plutons are hydrothermally altered. The area is also traversed by a northeasttrending shear zone containing mylonite, but has few traces of mineralization. 
An irregular, northeast-trending, magnetic high ridge corresponds with the distribution of the plutonic rocks, and a magnetic low embayment in this ridge coincides in part with the shear zone.

Thirty-one geochemical samples containing anomalous amounts of the five metals were collected. The samples include 13 stream-sediment samples, 3 soil samples, and 15 rock samples. Of the rock samples, 8 are of plutonic rocks; 5 are of metavolcanic rocks; and 2 are from contact zones of granitic and metavolcanic rocks. Most of the rock samples are either altered, silicified, or both, and stained by limonite; several contain disseminated pyrite. Among the entire group of samples, 6 contain anomalous amounts of silver; 12, copper; 6, molybdenum; 13, lead; and 3, zinc. With the exception of a few of the lead anomalies, which are as much as $500 \mathrm{ppm}$, the values of the anomalies are low.

Mining properties include the Curren Mountain prospect, Satan Lake prospect, Maid of Erin mine, and the Summit mine. The Curren Mountain prospect, Maid of Erin mine, and the Summit mine contain silver resources, but these resources are in quartz veins in which silver was subordinate to gold (see section on gold).

Most metallic anomalies are low, but on the basis of their abundance and the presence of hydrothermally altered rocks, area 7 has a moderate potential for volcanogenic deposits containing resources of lead, copper, and silver. Although measured resources and perhaps undiscovered resources of silver exist in vein deposits, any large ore bodies would more likely be volcanogenic deposits or porphyry deposits in plutonic rocks.

\section{Area 8}

Area 8 (fig. 1), the Red Ledge area, occupies $8 \mathrm{mi}^{2}$ (21 $\mathrm{km}^{2}$ ) and extends from the lower part of Deep Creek to the northeast across Anderson Gulch to and including much of the drainage of Oxbow Creek (pl. 1). The area includes the Red Ledge mine, a somewhat honorary title as no ore has been produced from the large, low-grade, mineralized body that has long been known to exist there.

The country rock is chiefly meta-andesite tuff and flows with some rhyolite porphyry, and minor metabasalt, all belonging to the Seven Devils Group. The rocks are folded in an anticline that is flexed from a north-northeast strike in the south to an east-northeast trend toward the north. Disseminated pyrite is abundant in some of the andesite and rhyolite, and sparse amounts of pyrite are present throughout much of the area. Alteration is pronounced and oxidation of pyrite has imparted red, orange, and brown colors to many outcrops, particularly near the Red Ledge mine. Much of the andesite is slightly silicified, and the andesite at the south side of the area is highly silicified.

A zone of low magnetic intensity extends from near the south tip of the study area to Heavens Gate. The zone is widest in the Red Ledge area where it consists of two deep troughs, the lowest magnetic intensities in the study area. The deeper trough is near the Red Ledge mine (pl. 1), where the reduction of the magnetic field is attributed to hydrothermal alteration; the other trough is in the south part of area 8 , where local silicification is prominent.

Twenty-five geochemical samples containing anomalous amounts of the five metals include 11 stream-sediment samples, 1 soil sample, and 13 rock samples. The rock samples include 2 of rhyolite and 11 of meta-andesite; 7 of the samples of andesite are altered, stained by limonite, and contain pyrite, and another is silicified. Among the entire group of samples, 14 contain anomalous amounts of silver; 3 , copper; 6 , molybdenum; 10 , lead; and 14, zinc. With the exception of one sample of andesite containing $15 \mathrm{ppm}$ of silver, and one stream-sediment sample containing 1,500 ppm of zinc, all anomalous values are low.

In addition to the Red Ledge mine, mining properties include the Cliff prospect and the Heady prospect. The Red Ledge mine and the Cliff prospect contain 25,318,000 tons $(22,969,000 \mathrm{t})$ of paramarginal copper, silver, and gold resources.

The combination of extensive mineralization, hydrothermal alteration and silicification, and large known resources in conjunction with geochemical and geophysical anomalies indicate a favorable environment for ore deposits. Accordingly, area 8 is classified as having a high potential for volcanogenic deposits containing resources of copper, silver, zinc, lead, and gold.

\section{Area 9}

Area 9 (fig. 1) occupies about $0.75 \mathrm{mi}^{2}\left(2 \mathrm{~km}^{2}\right)$ on the east side of Granite Creek, north of Emerald Lake (pl. 1). The area is underlain by metavolcanic rocks of the Seven Devils Group and by a small plug of granite that intrudes the metavolcanic rocks. The area is adjacent to the west side of one tabular pluton of diorite and the north end of another tabular body of diorite, both of which intrude the Seven Devils Group.

The area does not correspond to any magnetic anomaly, occurring on a slope of magnetic relief dipping westward from a magnetic high that coincides with the tabular body of diorite to the east.

Seven geochemical samples, including 5 stream-sediment samples and 2 rock samples, contain anomalous amounts of silver, copper, molybdenum, or lead. One of the rock samples is a hydrothermally altered and silicified andesite, and the other is an altered granite that is stained by limonite. The andesite contains 700 ppm molybdenum, and one of the stream-sediment samples contains $50 \mathrm{ppm}$ molybdenum. Of the 7 samples, 1 contains an anomalous amount of silver; 2, copper; 6, molybdenum; and 3, lead.

No mining properties are known in this area.

Area 9 has moderate potential for resources of molybdenum in a volcanogenic deposit because of the hydrothermal alteration in the area and the geochemical anomalies. Because stream-sediment samples indicate the general metallic content of an area better than rock samples, the presence of anomalous 
amounts of molybdenum in four adjacent streamlets in the horizontal distance of a mile across the slope above Granite Creek may be significant.

\section{Area 10}

Area 10 (fig. 1) occupies about $0.3 \mathrm{mi}^{2}\left(0.9 \mathrm{~km}^{2}\right)$ on the north side of Paradise Creek (pl. 1). The area is underlain by poorly exposed metavolcanic rocks of the Seven Devils Group.

Area 10 is at the west end of an east-trending magnetic low that may indicate hydrothermal alteration in the metavolcanic rocks. However, this magnetic trough crosses major thrust faults and different lithologies to the east, and because little hydrothermal alteration was noted in the poorly exposed rocks in the area, the interpretation of the magnetic anomaly is uncertain.

Three stream-sediment samples containing anomalous amounts of silver were collected from streamlets draining the slope above Paradise Creek; the anomalous values are low.

No mining properties are known in the area.

Area 10 has a moderate potential for a silver resource in a volcanogenic deposit because of the three anomalous streamsediment samples, and because of the possible relation of these samples to hydrothermally altered rocks that may underlie the area.

\section{Area 11}

Area 11 (fig. 1) occupies $0.25 \mathrm{mi}^{2}\left(0.6 \mathrm{~km}^{2}\right)$ near Casey Spring on the southwest side of Granite Creek (pl. 1). The area is underlain by poorly exposed metavolcanic rocks of the Seven Devils Group.

This area coincides with a very strong magnetic low. The low is in the same magnetic trough in which the Red Ledge area (area 8) is located; being only 3,500 ft (1,060 m) from that area, it seems quite possible that the magnetic low in area 11 may be the result of strong hydrothermal alteration-as seems to be the condition at the Red Ledge mine.

Only two geochemical samples were collected in this area: a stream-sediment sample containing anomalous amounts of silver, lead, and zinc, and a sample of altered metaandesite containing anomalous amounts of the same metals and a high value of molybdenum (70 ppm).

No mining properties are known in the area.

Area 11 has a moderate potential for resources of silver and lead in a volcanogenic deposit; the association of the geochemical anomalies with the magnetic anomaly may indicate a small area of intense alteration.

\section{Area 12}

Area 12 (fig. 1) occupies about $0.75 \mathrm{mi}^{2}\left(2 \mathrm{~km}^{2}\right)$ on the north side of Copper Creek and the south and southeast sides of Jackley Mountain (pl. 1). The area is underlain by metavolcanic rocks of the Seven Devils Group and is between plutons containing quartz diorite at Jackley Mountain and the south end of Middle Mountain.

The area largely coincides with a magnetic high, which is aligned with the northeast projection of the tabular pluton exposed at the south end of Middle Mountain. This high may represent a small cupola of quartz diorite at shallow depth beneath the area.

Eight geochemical samples contain anomalous amounts of the five metals. The samples include five stream-sediment samples and three rock samples of metavolcanic rocks, one of which contains disseminated pyrite. Four samples contain anomalous amounts of silver; 1, copper; 3, molybdenum; 2, lead; and 2, zinc. All of the anomalous values are low.

Silver mining properties are located on quartz fissure veins that contain disseminated pyrite and chalcopyrite. The veins have been explored for gold and silver deposits.

Area 12 has a moderate potential for resources of molybdenum and silver in volcanogenic deposits on the basis of the geochemical anomalies and the possibility of metals being concentrated in a thin roof above the protrusion of a pluton.

\section{Area 13}

Area 13 (fig. 1) occupies $0.5 \mathrm{mi}^{2}\left(1.3 \mathrm{~km}^{2}\right)$ between Granite Creek and West Fork Rapid River and at Carbonate Hill (pl. 1). The area is underlain by metavolcanic rocks of the Seven Devils Group. The south end of the area is near the northwest side of a pluton of quartz diorite, and the north end of the area is $7,000 \mathrm{ft}$ $(2,100 \mathrm{~m})$ southeast of a pluton of granodiorite.

An area of high magnetic intensity northwest of area 13 probably corresponds with the distribution of the pluton of granodiorite, which is partly stripped of its mantle of volcanic rocks in that direction. A nose of magnetic relief plunges southeast from the magnetic high into a trough-shaped magnetic low. This is the same northeast-trending trough in which the Red Ledge mine is located, but the trough is much narrower, and the magnetic intensity is not so low as in area 8. Area 13 coincides with the lower part of the nose of magnetic relief, and the south end of the area is in the trough.

Seven geochemical samples contain anomalous amounts of silver, molybdenum, lead, and zinc. The samples include two stream-sediment samples and five rock samples, all of metavolcanic rocks. Several of the rock samples are altered or silicified, and one is largely replaced by limonite. Of the samples, 3 contain anomalous amounts of silver; 3, molybdenum; 2, lead; and 3, zinc. With the exception of the rock replaced by limonite, which contains 50 ppm molybdenum, the anomalous values are low.

The Bald Eagle mine, a quartz fissure vein deposit, is in area 13; it has a recorded production of gold and silver, and contains submarginal gold-silver-copper-zinc resources.

Area 13 has a moderate potential for resources of silver, copper, zinc, and molybdenum in volcanogenic deposits, on the basis of the geochemical anomalies, the known mineralization and alteration, and the possibility of more intense 
mineralization and alteration at depth, which is suggested by the magnetic data.

\section{Area 14}

Area 14 (fig. 1) occupies a little more than $1 \mathrm{mi}^{2}\left(3 \mathrm{~km}^{2}\right)$ near Baldy Lake on the west side of the highest peaks in the Seven Devils Mountains (pl. 1). The area is underlain by metavolcanic rocks of the Seven Devils Group, and a pluton of granodiorite is exposed 1,000 to $2,500 \mathrm{ft}$ (305 to $760 \mathrm{~m}$ ) away from the southwest side of the area.

Area 14 does not coincide with any magnetic anomaly, being on the upper part of a slope of magnetic relief that dips east from a high near the pluton of granodiorite toward a low magnetic trough some distance away.

Fourteen geochemical samples contain anomalous amounts of silver, copper, molybdenum, or zinc. The samples include 10 stream-sediment samples and four rock samples, all of which contain disseminated pyrite. Among the 14 samples, 7 contain anomalous amounts of silver; 3 , copper; 2, molybdenum; and 8, lead. The highest anomalous values are in a sample of metabasalt, which contains 1,000 ppm copper, and in three stream-sediment samples, which contain 150, 200, and 300 ppm lead, respectively.

No production or resources are known from mining properties in the area.

Area 14 has a moderate potential for resources of lead and silver in volcanogenic deposits because of the large number of geochemical samples-particularly the stream-sediment samples - that contain anomalous amounts of metals.

\section{Area 15}

Area 15 (fig. 1) occupies about $0.5 \mathrm{mi}^{2}\left(1.3 \mathrm{~km}^{2}\right)$ near Gem Lake on the north side of He Devil in the Seven Devils Mountains (pl. 1). The area is underlain by metavolcanic rocks of the Seven Devils Group and is nearly $2 \mathrm{mi}(3 \mathrm{~km})$ from the nearest exposed pluton to the southwest.

Area 15 does not coincide with any magnetic anomaly, being on the upper part of a slope of magnetic relief that dips eastward from a west-trending magnetic high toward a northtrending magnetic trough. The magnetic high may correlate with a plutonic body at depth. The trough is the same feature that extends from the southern part of the study area to Heavens Gate, and is associated with some of the other areas having moderate or high potentials for mineral resources.

Seven stream-sediment samples contain anomalous amounts of lead, 1 of silver, and 2 of copper. All of the anomalous values are low.

No production or resources are known from mining properties in the area.

Area 15 has a moderate potential for a lead resource in volcanogenic deposits because of the concentration of streamsediment samples containing anomalous amounts of that metal.

\section{Area 16}

Area 16 (fig. 1) occupies nearly $5 \mathrm{mi}^{2}\left(13 \mathrm{~km}^{2}\right)$ in the canyon of the Snake River in the drainages of Sluice Creek, Rattlesnake Creek, Rush Creek, and Pony Creek in Oregon, and near Johnson Bar in Idaho (pl. 1). The area is underlain by metavolcanic rocks of the Seven Devils Group and is near the north side of a pluton of granodiorite. The rocks in much of the area are hydrothermally altered, and locally they are silicified and stained by limonite.

The area has no apparent relation to magnetic features. A narrow east-west ridge of high magnetic intensity crosses the northern part of the area, and a narrow, parallel trough of low intensity, at the edge of the pluton of granodiorite, crosses the southern part.

Twenty-one rock samples contain anomalous amounts of the five metals. Most of the rocks are altered, silicified, stained by limonite, or contain disseminated pyrite; a few contain visible sulfides other than pyrite. Seven samples contain anomalous amounts of silver; 7, copper; 11, molybdenum; 9, lead; and 7 , zinc. Many of the anomalous values were high: as much as 15 ppm silver, more than 20,000 ppm copper, 500 ppm molybdenum, 300 ppm lead, and 10,000 ppm zinc.

Mining properties in the area include the Hat Point prospect that contains 52,500 tons $(47,600 \mathrm{t})$ of submarginal copper resources.

Area 16 has a moderate potential for resources of silver, copper, molybdenum, lead, and zinc in volcanogenic deposits, on the basis of the extensive hydrothermal alteration, mineralization and known resources, and the highly anomalous values of metals found in some of the geochemical samples.

\section{Area 17}

Area 17 (fig. 1) occupies $2 \mathrm{mi}^{2}\left(5.2 \mathrm{~km}^{2}\right)$ in the canyon of the Snake River near Quartz Creek and Dry Gulch in Oregon, and near Meyer Creek and Caribou Creek in Idaho (pl. 2). The area is underlain by metavolcanic rocks of the Seven Devils Group, and is more than $1 \mathrm{mi}(1.6 \mathrm{~km})$ from the nearest plutonic rocks to the southeast and 0.25 to $1 \mathrm{mi}(0.4$ to $1.6 \mathrm{~km})$ southwest of a major northeast-trending shear zone. Many of the metavolcanic rocks are hydrothermally altered, and locally they are silicified, stained by limonite, or contain disseminated pyrite.

Basins of low magnetic intensity at Sand Creek in Oregon (pl. 1) and near Kirkwood Creek in Idaho (pl. 2) are linked by a trough that extends northeast from Sand Creek and then flexes east into the drainage of Kirkwood Creek. Area 17 is in the bottom and on the west side of the trough, just south of the flexure.

Thirteen geochemical samples contain anomalous amounts of the five metals. The samples include 3 streamsediment samples, 1 soil sample, and 9 rock samples. The rock samples are chiefly metabasalt and meta-andesite, but include one metavolcanic rock that is too altered for identification 
and one of limonitized material from a small zone of crushed metavolcanic rock. Of the thirteen samples, 6 contain anomalous amounts of silver; 4, copper; 5, molybdenum; 2, lead; and 6 , zinc. Most of the anomalous values are low.

No production or resources are known from mining properties in the area.

Area 17 has a moderate potential for resources of silver, zinc, molybdenum, and copper in volcanogenic deposits, on the basis of the association of geochemical anomalies and hydrothermal alteration, and the possibility of more extensive alteration and mineralization at depth as suggested by the magnetic data.

\section{Area 18}

Area 18 (fig. 1), the Blue Jacket area, occupies $2.5 \mathrm{mi}^{2}$ $\left(6.5 \mathrm{~km}^{2}\right)$ in the upper parts of the drainages of Kirkwood Creek, Kirby Creek, and Corral Creek in the vicinity of the Blue Jacket mine (pl. 2). The area is underlain by metavolcanic rocks of the Seven Devils Group, which are in part hydrothermally altered and stained by limonite. The area is not near any large body of plutonic rock, although a pluton of granodiorite occurs about $1.5 \mathrm{mi}(2.4 \mathrm{~km})$ northwest of the north end of the area and a plug of diorite occurs 3,000 ft $(910 \mathrm{~m})$ northwest of the south end of the area. Parts of a major northeast-trending shear zone are about $1 \mathrm{mi}(1.6 \mathrm{~km})$ or more northwest of the area.

The south end of the Blue Jacket area coincides with the bottom of a basin of low magnetic intensity, and from there the area extends northeast in a band that approximately corresponds to a swale, defined by lines of magnetic intensity. Because the altered rocks in the Blue Jacket area coincide with parts of the magnetic swale, it seems likely that alteration is responsible for the low magnetic intensity, and that altered rocks other than those exposed at the surface contribute to the configuration of the magnetic low.

Five geochemical samples, exclusive of samples from mine workings, were collected in area 18; all are samples of altered metavolcanic rocks. Three of the samples contain anomalous amounts of silver; 1 , molybdenum; 1 , lead; and 2 , zinc. In addition, a detailed geochemical survey of soil samples by a private mining company indicates that a concentration of zinc occurs in a large area northeast of the Blue Jacket mine.

Mining properties in the area include the Blue Jacket mine and the Virginia group. The former contains 1,900,000 tons $(1,700,000 \mathrm{t})$ of paramarginal copper-silver-gold resources, and the latter contains 84,000 tons $(76,000 \mathrm{t})$ of submarginal coppersilver-gold resources.

Area 18 has a high potential for resources of zinc and silver in volcanogenic deposits. The occurrence of anomalous geochemical values in altered rocks and soil samples, the coincidence of these in a zone of low magnetic intensity, and the known mineralization and resources strongly suggest the presence of ore bodies.

\section{Area 19}

Area 19 (fig. 1) occupies $0.75 \mathrm{mi}^{2}\left(2 \mathrm{~km}^{2}\right)$ in the drainage of the upper part of Somers Creek (pl. 2). The area is underlain by nearly horizontal flows of the Columbia River Basalt Group. The basalt probably overlies metavolcanic rocks of the Seven Devils Group, and possibly overlies sedimentary rocks of the Kurry Creek Member of the Doyle Creek Formation. A north-trending, post-Miocene fault was mapped north of area 19 , and it is possible that the fault transects the area, although its presence was not determined at its nearest approach.

The area is on a slope of steep magnetic relief in part representing the change from a thick cover of basalt that has a high magnetic intensity to the west, to sedimentary rocks that have a low magnetic intensity to the east, and in part representing the topographic high of Summit Ridge and its environs to the west and the topographic low of the Pittsburg Landing area to the east. The change in magnetic relief may be also in part the result of a fault that may truncate the sedimentary rocks beneath the basalt. The projected strike of the fault passes through area 18, parallel to the strike of the magnetic slope.

Three geochemical samples containing anomalous amounts of silver, copper, lead, and zinc were collected in the area. Two stream-sediment samples (HP 0137 and HP 0138) contain exceptionally high values of metals: HP 0137 contains 70 ppm silver; 1,500 ppm copper; 3,000 ppm lead; and 10,000 ppm zinc; in addition, the sample contains anomalous amounts of gold and cadmium. HP 0138 contains 7 ppm silver; 300 ppm copper; 1,000 ppm lead; and 1,500 ppm zinc, and also contains an anomalous amount of gold. A third stream-sediment sample from another small tributary to Somers Creek (HP 0139) contains an anomalous amount of gold. The quantities of silver, lead, and zinc found in HP 0137 and HP 0138 were the greatest amounts determined among all stream-sediment samples collected during the study.

The Columbia River Basalt Group is nowhere known to be mineralized; anomalies found in the basalt are weak and are merely extremes in normal variation. Likewise, sediment samples from streams that drain only basalt contain only low amounts of metals. It seems reasonable to conclude, therefore, that the metal content of the sediment samples was not derived from the basalt, but must have somehow been derived from a nearby source beneath the basalt.

For such large amounts of metals to accumulate in tributaries to Somers Creek, it is likely that the mineralized source rock under the basalt would be at a higher elevation than the mouths of the streams where the samples were collected; this would be necessary in order that ground water that leached the mineralized rock could move downward to enter the surface drainage of the streamlets. Local relief of as much as 2,000 ft $(610 \mathrm{~m})$ occurs on the pre-basalt surface, and as much as $800 \mathrm{ft}$ (240 m) of relief is known to occur on that surface near Somers Creek (pl. 2). So, it is possible that the tops of buried hills on the prebasalt surface are at higher elevations than the mouths of the streamlets that enter Somers Creek. Because the sites where the 
stream-sediment samples were collected are in alignment with the projected strike of the post-basalt fault, it seems possible that the fault may have facilitated the circulation of water, although this is not a necessary part of the explanation.

The high metal values in the stream-sediment samples are indicative of a highly mineralized source nearby, probably a volcanogenic deposit in rocks of the Seven Devils Group, but because of the uncertainties regarding the location of the source rocks and thickness of basalt overlying them, area 19 is classified as having a moderate potential for a silver-lead-zinccopper resource.

\section{Area 20}

Area 20 (fig. 1) occupies $2.5 \mathrm{mi}^{2}\left(6.5 \mathrm{~km}^{2}\right)$ near the confluence of the Imnaha and Snake Rivers (pl. 2). The area is underlain by a pluton that ranges in composition from gabbro to diorite to quartz diorite and contains inclusions of metavolcanic rocks of the Seven Devils Group. Many fissure veins occur in the plutonic rocks. The veins are commonly only a few inches thick, but some are thicker; they contain magnetite, specular hematite, pyrite, and at some places, small amounts of chalcopyrite, and the oxidation products of these minerals, limonite, malachite, and rarely azurite.

The southwest part of area 20 coincides with the northeast part of a magnetic high, but most of the area is on a slope of magnetic relief between the high and a magnetic low that corresponds with a large zone of sheared rocks to the northeast. Much of the magnetic high is at the same place as an area overlain by the Columbia River Basalt Group, but the configuration of the magnetic high may be determined by the distribution of the more basic rocks in the underlying pluton or by the abundant magnetite in veins in the pluton.

Fourteen geochemical samples contain anomalous amounts of silver, copper, molybdenum, or zinc. Of these, 9 are stream-sediment samples and 5 are rock samples. The rock samples include one from an andesite dike, 2 of quartz diorite, and 2 from fissure veins in diorite. Of the entire group of samples, 13 contain anomalous amounts of copper; 1, silver; 2 molybdenum; and 1, zinc.

Mining claims are located on numerous veins in the area. Among these are the Fargo group and the Imnaha Rapids prospect, which contain 302,500 tons $(274,400 \mathrm{t})$ of submarginal copper resources, mostly at the Fargo group.

Area 20 has a moderate potential for a copper resource in vein deposits on the basis of the large number of known occurrences and the geochemical samples indicating its presence. However, the deposits thus far discovered are small and low grade, and the association of copper with magnetite and hematite would hinder the recovery of the copper.

\section{Area 21}

Area 21 (fig. 1), the Dry Diggins area, occupies less than $0.25 \mathrm{mi}^{2}\left(0.65 \mathrm{~km}^{2}\right)$ on Dry Diggins Ridge (pl. 1). The gravel overlies metavolcanic rocks of the Seven Devils Group, but the Columbia River Basalt Group that once overlaid the gravels has been entirely eroded.

Area 21 has a moderate potential for a placer gold resource, but water would have to be supplied in order to mine the deposit.

\section{Other Deposits}

Numerous prospects and mines outside of areas 1 through 21 contain anomalous amounts of the five metals, especially copper and silver. Even though some of the mines contain resources of the metals, the areas in which they occur nonetheless have a low mineral resource potential. These occurrences are small and low grade and are not associated with significant geochemical anomalies, magnetic anomalies, or a favorable geologic environment. This does not necessarily signify that no new ore deposits will be found.

\section{Gold}

Gold resources would be restricted to those types of deposits from which the metal was mined in the past, that is, placer deposits, quartz fissure veins, and volcanogenic deposits. The gold in volcanogenic deposits is present in only minor quantities, and has been or would be only a byproduct of mining for other metals. Therefore, the potential of an area for gold depends on the potential of that area for having volcanogenic deposits of silver, copper, molybdenum, lead, or zinc.

Gold was found at the Nix claim group in area 1, the Red Ledge mine and the Cliff prospect in area 8, and the Blue Jacket mine and the Virginia group in area 18. Areas 8 and 18 have a high potential for a gold resource in volcanogenic deposits, and area 1 has a moderate potential.

A mineral deposit probably underlies the Columbia River Basalt Group in area 19. No mines are present, but 3 streamsediment samples-HP 0137, HP 0138, and HP 0139 (table 4)_contain anomalous amounts of gold. Area 19 is therefore classified as having a moderate potential for a gold resource in a volcanogenic deposit.

Quartz fissure veins were mined for their gold content, but also contained small amounts of silver. Both metals were detected in geochemical samples from a few prospects and at mines where resources exist. However, no gold was found in samples collected near the veins or in the areas in which the veins occur, and the evaluation of the potential for gold-silver vein deposits is determined by the presence of the metals in unmined deposits exposed in mines.

In area 7 the Curren Mountain prospect contains 25,300 tons $(22,950 \mathrm{t})$ of submarginal gold-silver resources, and the Maid of Erin mine and the Summit mine contain 328,000 tons (298,000 t) of paramarginal gold-silver resources. Area 7 is accordingly classified as having a moderate potential for gold-silver resources in fissure vein deposits. 
In area 12 the Mayflower group, White Rose prospect, Holbrook Saddle prospect, and the Middle Mountain prospect are located on quartz fissure veins; the area is classified as having a moderate potential for gold and silver resources in vein deposits.

In area 13 the Bald Eagle mine contains 18,750 tons $(17,010 \mathrm{t})$ of submarginal gold-silver resources; the area is classified as having a moderate potential for gold-silver resources in fissure vein deposits.

Placer deposits may exist along the Snake River in the present riverbed and in terraces above the river, and in highlevel gravels on the pre-Columbia River Basalt Group erosion surface. Past mining operations and studies carried out during the present study indicate that deposits along the Snake River are small and that the small size of the particles of gold would render their recovery difficult. The potential for the discovery of a gold resource in placer deposits along the Snake River is low.

Gold occurs in high-level gravels at Crooks Corral Basin and Dry Diggins (area 21). The deposits at Crooks Corral Basin are practically mined out, and past attempts to mine at Dry Diggins have been unsuccessful.

\section{Tungsten}

Tungsten occurs in parts of area 3, where tactite deposits containing scheelite and powellite are associated with limestone inclusions in the pluton near White Monument (pl. 1). Tungsten has been found at a number of prospects and mines in this vicinity, and the Alaska mine, just outside of the study area, produced a small amount of tungsten ore. The only geochemical samples collected for this study that contain anomalous amounts of tungsten were HG 1134, HS 0856, and HS 0897. On the basis of these occurrences and samples, area 3 has a moderate potential for a tungsten resource in tactite deposits.

\section{Nonmetallic Mineral Resources}

Limestone suitable for agricultural and metallurgical purposes and for making lime cement occurs in the Martin Bridge Limestone; abundant basalt in the Columbia River Basalt Group could be used for riprap and road building; and sand and gravel, chiefly in terraces along the Snake River, are suitable for construction. These materials, however, are too remote from major markets to compete with more readily accessible sources elsewhere.

\section{References Cited}

Anderson, A.L., 1930, The geology and mineral resources of the region about Orofino, Idaho: Idaho Bureau of Mines and Geology Pamphlet 34, 63 p.
Balcer, D.E., $1980,{ }^{40} \mathrm{Ar} /{ }^{39} \mathrm{Ar}$ ages and REE geochemistry of basement terranes in the Snake River Canyon, northeastern Oregonwestern Idaho: Ohio State University, M.S. thesis, 111 p.

Baski, A.K., and Watkins, N.D., 1973, Volcanic production rates-Comparison of oceanic ridges, islands, and the Columbia Plateau basalts: Science, v. 180, p. 493-496.

Bhattacharyya, B.K., and Chan, K.C., 1977, Reduction of magnetic and gravity data on an arbitrary surface acquired in a region of high topographic relief: Geophysics, v. 42, no. 7 , p. 1,411-1,430.

Brooks, H.C., 1978, Mesozoic rocks and tectonic evolution of eastern Oregon and western Idaho: Society of Economic Paleontologists and Mineralogists, Pacific Section, Mesozoic Symposium, v. 2, p. 133-145.

Brooks, H.C., and Vallier, T.L., 1967, Progress report on the geology of part of the Snake River Canyon, Oregon and Idaho: Oregon Department of Geology and Mineral Industries, The Ore Bin, v. 29, no. 12, p. 233-267.

Brott, C.A., Blackwell, D.D., and Mitchell, J.C., 1976, Heat flow in the Snake River Plain region, southern Idaho: Idaho Department of Water Resources, Water Resources Water Information Bulletin 30, pt. 8, p. 195.

Cook, E.F., 1954, Mining geology of the Seven Devils region: Idaho Bureau of Mines and Geology Pamphlet 97, 22 p.

Gilluly, J., Reed, J.C., and Park, C.F., Jr., 1933, Some mining districts of eastern Oregon: U.S. Geological Survey Bulletin 846-A, $140 \mathrm{p}$.

Goudarzi, G.H. (compiler), 1984, Guide to preparation of mineral survey reports on public lands: U.S. Geological Survey Open-File Report 84-787, 50 p.

Grimes, D.J., and Marranzino, A.P., 1968, Direct-current arc and alternating-current spark emission spectrographic field methods for semiquantitative analysis of geologic materials: U.S. Geological Survey Circular 591, 6 p.

Hamilton, Warren, 1960, Metamorphism and thrust faulting in the Riggins quadrangle, Idaho, in Geological Survey Research 1960: U.S. Geological Survey Professional Paper 400-B, p. 230-231.

Hamilton, Warren, 1962, Late Cenozoic structure of west-central Idaho: Geological Society of America Bulletin, v. 73, no. 4, p. 511-515.

Hamilton, Warren, 1963a, Columbia River Basalt in the Riggins quadrangle, western Idaho: U.S. Geological Survey Bulletin 1141-L, $37 \mathrm{p}$.

Hamilton, Warren, 1963b, Metamorphism in the Riggins region, western Idaho: U.S. Geological Survey Professional Paper 436, 95 p. 
Hamilton, Warren, 1965, Overlapping of late Mesozoic orogens in western Idaho: Geological Society of America Bulletin, v. 74, p. 779-788.

Hamilton, Warren, 1969, Reconnaissance geologic map of the Riggins quadrangle, west-central Idaho: U.S. Geological Survey Miscellaneous Geologic Investigations Map I-579, scale $1: 125,000$.

Holden, G.S., and Hooper, P.R., 1976, Petrology and chemistry of a Columbia River Basalt section, Rocky Canyon, west-central Idaho: Geological Society of America Bulletin, v. 87 , no. 2 , p. 215-225.

Hoyt, W.G., 1925, Power resources of the Snake River between Huntington, Oregon, and Lewiston, Idaho: U.S. Geological Survey Water Supply Paper 520-C, p. 27-51.

Libbey, F.W., 1943, Some mineral deposits in the area surrounding the junction of the Snake and Imnaha Rivers in Oregon: Oregon Department of Geology and Mineral Industries, GMI Short Paper 11, 17 p.

Lindgren, Waldemar, 1899, The copper deposits of the Seven Devils, Idaho: Mining Science Press, v. 78, p. 125.

Lindgren, Waldemar, 1900, The gold and silver veins of Silver City, De Lamar, and other mining districts in Idaho: U.S. Geological Survey 20th Annual Report, pt. 3, p. 65-256.

Lindgren, Waldemar, 1901, The gold belt of the Blue Mountains of Oregon: U.S. Geological Survey 22d Annual Report, p. 551-776.

Livingston, D.C., 1932, A major overthrust in western Idaho and northeastern Oregon: Northwest Science, v. 6, no. 2, p. 31-36.

Livingston, D.C., and Laney, F.B., 1920, The copper deposits of the Seven Devils and adjacent districts: Idaho Bureau of Mines and Geology Bulletin 1, 105 p.

Lupher, R.L., 1941, Jurassic stratigraphy of central Oregon: Geological Society of America Bulletin, v. 52, no. 2, p. 219-269.

Morganti, J.M., 1972, Geology and ore deposits of the Seven Devils Volcanics, Seven Devils mining district, Hell's Canyon, Idaho: Pullman, Wash., Washington State University, M.S. thesis, $153 \mathrm{p}$.

Morrison, R.F., 1963, The pre-Tertiary geology of the Snake River Canyon between Cache Creek and Dug Bar, OregonIdaho boundary: Eugene, Oreg., University of Oregon, Ph.D. dissertation, $195 \mathrm{p}$.

Morrison, R.F., 1964, Upper Jurassic mudstone unit named in Snake River Canyon, Oregon-Idaho boundary: Northwest Science, v. 38, p. 83-87.
Nolf, B., 1966, Geology and stratigraphy of the northern Wallowa Mountains, Oregon: Princeton, N.J., Princeton University, Ph.D. dissertation, 138 p.

Ozier, R.L., 1971, The geology of the Tertiary-Pretertiary angular unconformity-McGraw Creek to the Grande Ronde River, Snake River Canyon, Oregon and Washington: Indiana State University, M.S. thesis, 86 p.

Packard, R.L., 1895, On occurrence of copper in western Idaho: American Journal of Science, 3d series, v. 50, p. 298-300.

Reed, G.D., 1907, The Seven Devils and the Snake River district: Engineering Mining Journal, v. 84, p. 401.

Ross, C.P., 1938, The geology of part of the Wallowa Mountains: Oregon Department of Geology and Mineral Resources Bulletin 3, 74 p.

Simmons, G.C., and Close, T.J., 1984, Hells Canyon study area, Oregon and Idaho, in Marsh, S.P., Kropschot, S.J., and Dickinson, R.G., eds., Wilderness mineral potentialAssessment of mineral-resource potential in U.S. Forest Service lands studied 1964-1984: U.S. Geological Survey Professional Paper 1300, p. 875-878.

Simmons, G.C., Gualtieri, J.L., Close, T.J., Federspiel, F.E., and Leszcykowski, A.M., and Hyndman, P.C., 1983, Mineral resource potential of the Hells Canyon Wilderness and contiguous roadless areas, Wallowa County, Oregon, and Idaho and Adams Counties, Idaho: U.S. Geological Survey Open-File Report 83-397, 20 p.

Simmons, G.C., Sutley, S.J., Forn, Carl, Viets, J.G., Hopkins, D.M., Negri, J.C., and Curtis, C.A., 1984, Analytical data for the Hells Canyon study area, Wallowa County, Oregon, and Idaho and Adams Counties, Idaho: U.S. Geological Survey Open-File Report 84-499, 156 p., 4 pls.

Swartley, A.M., 1914, Ore deposits of northeastern Oregon: Oregon Bureau of Mines and Geology, Mineral Resources of Oregon, v. 1, no. 8, 229 p.

Taylor, R.B., and Steven, T.A., 1983, Definition of mineral resource potential: Economic Geology, v. 78, p. 1,2681,270 .

Umpleby, J.B., 1916, The occurrence of ore on the limestone side of garnet zones: University of California Bulletin, Department of Geology, v. 10, no. 3, p. 25-37.

U.S. Bureau of Mines and U.S. Geological Survey, 1976, Principles of the mineral resource classification system of the U.S. Bureau of Mines and U.S. Geological Survey: U.S. Geological Survey Bulletin 1450-A, 5 p.

U.S. Forest Service, 1979, Draft environmental impact statement, Hells Canyon National Recreation Area land management plan: U.S.D.A., Forest Service, 206 p. 
U.S. Geological Survey, 1980, Aeromagnetic map of the Hells Canyon aea, Idaho and Oregon: U.S. Geological Survey Open-File Report 80-947, 1 sheet.

Vallier, T.L., 1967, The geology of part of the Snake River Canyon and adjacent areas in northeastern Oregon and western Idaho: Corvallis, Oreg., Oregon State University, Ph.D. dissertation, 267 p.

Vallier, T.L., 1973, Geologic map of the Snake River Canyon, Oregon and Idaho, in Vallier, T.L., 1974, A preliminary report on the geology of part of the Snake River Canyon, Oregon, and Idaho: Oregon Department of Geology and Mineral Industries, Geologic Map Series, GMS-6, 15 p.

Vallier, T.L., 1974, A preliminary report on the geology of part of the Snake River Canyon, Oregon and Idaho: Oregon Department of Geology and Mineral Industries, Geologic Map Series, GMS-6, 15 p.

Vallier, T.L., 1977, The Permian and Triassic Seven Devils Group, western Idaho and northeastern Oregon: U.S. Geological Survey Bulletin 1437, 58 p.

Vallier, T.L., and Batiza, R., 1978, Petrogenesis of spilite and keratophyre from a Permian and Triassic volcanic arc terrane, eastern Oregon and western Idaho, U.S.A.: Canadian Journal of Earth Science, v. 15, no. 8, p. 1,356-1,369.

Vallier, T.L., and Brooks, H.C., 1970, Geology and copper deposits of the Homestead area, Oregon and Idaho: Oregon Department of Geology and Mineral Industries, The Ore Bin, v. 32, no. 2, p. 37-60.
Vallier, T.L., and Fredley, D., 1972, The Mirror Lake intrusive breccia, Seven Devils Mountains, western Idaho: Geological Society of America Bulletin, v. 83, p. 3,827-3,832.

Vallier, T. L., and Hooper, P.R., 1976, Geologic guide to Hells Canyon, Snake River: Pullman, Wash., Washington State University Department Geology Field Guide, no. 5, 38 p.

Vallier, T.L., and Miller, V.C., 1974, Landslides in the Snake River Canyon along the Oregon and Idaho boundary: Indiana State University Professional Paper 5, p. 3-22.

Wagner, W.R., 1945, A geological reconnaissance between the Snake and Salmon Rivers north of Riggins, Idaho: Idaho Bureau of Mines and Geology Pamphlet 74, 16 p.

Ward, F.N., Lakin, H.W., Canney, F.C., and others, 1963, Analytical methods used in geochemical exploration by the U.S. Geological Survey: U.S. Geological Survey Bulletin $1152,100 \mathrm{p}$.

Watkins, N.D., 1965, Paleomagnetism of the Columbia Plateaus: Journal of Geophysical Research, v. 70, no. 6, p. $1,379-1,406$.

White, D.L., 1972, The geology of the Pittsburg Landing area, Snake River Canyon, Oregon-Idaho: Indiana State University, M.S. thesis, 98 p.

White, W.H., 1968, Plutonic rocks of the southern Seven Devils Mountains, Idaho: Corvallis, Oreg., Oregon State University, Ph.D. dissertation, 177 p. 


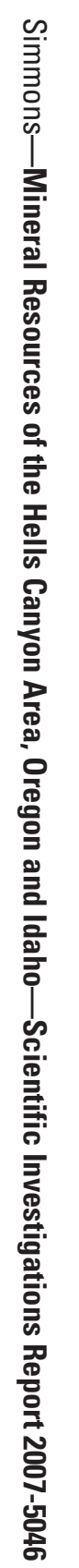

9 Printed on recycled paper 